BRUNO OLIVA OISHI

\title{
ESTUDO DA CAPACIDADE DE SORÇÃO DE COBRE POR Pseudomonas putida sp. EM REATOR
}

Tese apresentada ao Programa de PósGraduação Interunidades em Biotecnologia USP/ Instituto Butantan/IPT, para obtenção do Título de Doutor em Biotecnologia. 
BRUNO OLIVA OISHI

\section{ESTUDO DA CAPACIDADE DE SORÇÃO DE COBRE POR Pseudomonas putida sp. EM REATOR}

Tese apresentada ao Programa de PósGraduação Interunidades em Biotecnologia USP/Instituto Butantan/IPT, para obtenção do Título de Doutor em Biotecnologia.

Área de concentração: Biotecnologia

Orientador: $\operatorname{Prof}^{\mathrm{a}} \operatorname{Dr}^{\mathrm{a}}$ Beatriz Vahan Kilikian Co-Orientador: Dr. Ronaldo Biondo

Versão original 
DADOS DE CATALOGAÇÃO NA PUBLICAÇÃO (CIP)

Serviço de Biblioteca e Informação Biomédica do Instituto de Ciências Biomédicas da Universidade de São Paulo

(c) reprodução total

Oishi, Bruno Oliva.

Estudo da capacidade de sorção de cobre por Pseudomonas putida sp. em reator / Bruno Oliva Oishi. -- São Paulo, 2014.

Orientador: Profa. Dra. Beatriz Vahan Kilikian.

Tese (Doutorado) - Universidade de São Paulo. Instituto de Ciências Biomédicas. Programa de Pós-Graduação Interunidades em Biotecnologia USP/IPT/Instituto Butantan. Área de concentração: Biotecnologia. Linha de pesquisa: Biorremediação de áreas contaminadas com cobre.

Versão do título para o inglês: Study of Pseudomonas putida sp. cooper sorption capacity in bioreactor.

1. Pseudomonas 2. Biorremediação 3 . Cobre 4. Reatores bioquímicos I. Kilikian, Profa. Dra. Beatriz Vahan II. Universidade de São Paulo. Instituto de Ciências Biomédicas. Programa de PósGraduação Interunidades em Biotecnologia USP/IPT/Instituto Butantan III. Título. 


\section{UNIVERSIDADE DE SÃO PAULO \\ Programa de Pós-Graduação Interunidades em Biotecnologia}

Universidade de São Paulo, Instituto Butantan, Instituto de Pesquisas Tecnológicas

Candidato(a): $\quad$ Bruno Oliva Oishi.

Título da Tese: $\quad$ Estudo da capacidade de sorção de cobre por

Pseudomonas putida sp. em reator.

Orientador(a): $\quad$ Profa. Dra. Beatriz Vahan Kilikian.

A Comissão Julgadora dos trabalhos de Defesa da Tese de Doutorado, em sessão pública realizada a .................., considerou
( ) Aprovado(a)
( ) Reprovado(a)

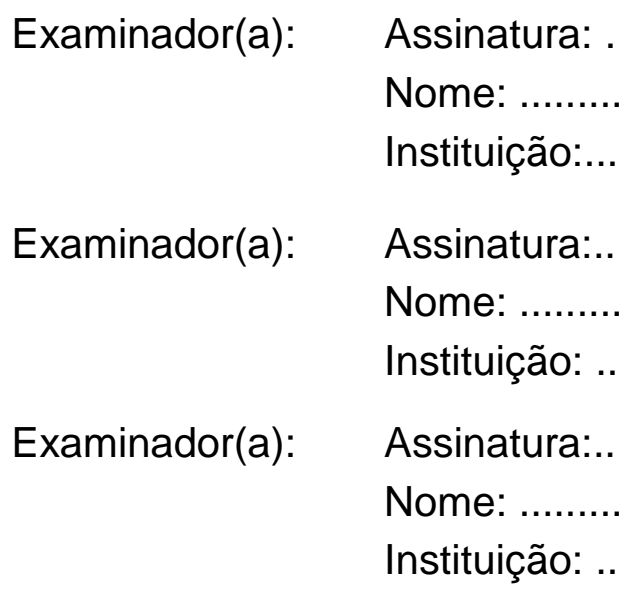

Examinador(a): Assinatura:

Nome:

Instituição:

Presidente: Assinatura:

Nome:

Instituição: 


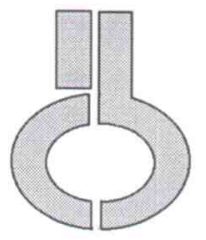

\section{CERTIFICADO DE ISENÇÃO}

Certificamos que o Protocolo CEP-ICB N ${ }^{\circ}$ 600/13 referente ao projeto intitulado: "Avaliação da capacidade de adsorção bacteriana de cobre em reator CSTR" sob a responsabilidade de Bruno Oliva Oishi, foi analisado na presente data pela CEUA - COMISSÃO DE ÉTICA NO USO DE ANIMAIS e pela CEPSH- COMISSÃo DE ÉTICA EM PESQUISA COM SERES HUMANOS, tendo sido deliberado que o referido projeto não utilizará animais que estejam sob a égide da lei 11.794 de 8 de outubro de 2008, nem envolverá procedimentos regulados pela Resolução CONEP n¹96 de 1996.

São Paulo, 26 de abril de 2013.

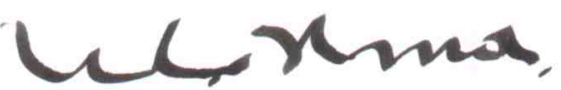

Prof. Dr. Wothan TAVARES DE Lima Coordenador da CEUA - ICB/USP

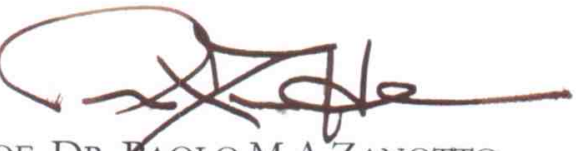

PROF. DR. PAOLO M.A ZaNoTTO Coordenador da CEPsh - ICB/USP 
Dedico à minha família: meu avô, meu pai, minha mãe, minha irmã, minha amada esposa Carolina e aos felinos que já fizeram e fazem parte da minha vida: Jack, Jinx, Mimi e Tonico. 


\section{AGRADECIMENTOS}

A minha querida orientadora Beatriz Vahan Kilikian, pela orientação, incentivo, dedicação e amizade em todos os momentos.

Aos meus pais, meu avô, minha irmã e a minha amada esposa Carolina por todo o amor, carinho, atenção, paciência que sem vocês não seria possível realizar este projeto.

Aos meus avós (in memoriam) por me ensinarem desde criança o valor e necessidade da educação.

Ao Prof. Claúdio Augusto Oller do Nascimento por me acolher de maneira incondicional em seu grupo e laboratório.

Ao Prof. Adalberto Pessoa Junior, que abriu as portas para mim na USP e me ajudou a encontrar o melhor caminho a ser seguido.

A Carminha por todos os conselhos e as longas conversas sobre a vida, doutorado e bons vinhos.

A Marilda pelos conselhos, apoio incondicional no desenvolvimento do projeto e a amizade.

Ao Sr. Antônio Lopes da Sotelab pela ajuda com os reatores da Infors.

Ao Paulo Firmino por toda a ajuda e paciência com os reatores.

Aos meus bons amigos do ICB, Taís (essa menina vale ouro), Felipe, Ciça, Arthur, Kazui, Tadeu, Norma, Carlinha, Diogo e Igor pela amizade, pelos jogos de vôlei às sextas-feiras.

Ao Rodrigo, Leila, Larissa, Jéssica ("Grupo USPício") pela ajuda no laboratório e também por todas as risadas e brincadeiras que amenizam o ambiente. 
Novamente a minha amiga Larissa pela ajuda continua em todos meus experimentos e pela amizade, que apesar das longas discussões técnicas sempre se manteve.

Aos funcionários do GEnBio, Orlinda, Andréa e Valter pela colaboração e amizade.

Aos amigos do GenBio, Pedro Henrique, Letícia, Fernanda, Rafael pela amizade e força.

A lara pela amizade e conselhos no início do doutorado, que foram fundamentais para minha formação.

A Amy Winehouse, Tulipa Ruiz, Mariana Aydar, Armandinho, Frejat, Titãs, Barão Vermelho, The Blues Brothers, Tihuana, Kid Abelha, Legião Urbana, Lenny Kravitz, Marron 5, Stacey Kent, Tianastácia, Beca Arruda, Cássia Eller, B.B. King, Bob Marley, Caetano Veloso, The Doors, Madeleine Peyroux, Fernanda Takai, Gilberto Gil, Jack Johnson, Little Richard, Marcelo D2, Marisa Monte, Nando Reis, Paralamas do Sucesso e Trash pour 4 por me fazer companhia através das boas músicas nas longas madrugadas que passei ao lado do reator.

Ao Dr. Flávio Moscardi (in memoriam) pelos elogios e incentivo no doutorado.

Ao Virgilio Vicino e Luís Henrique Rahmeier por me apoiarem no doutorado durante o tempo em que estive na Makhteshim Agan, além dos conselhos sobre a vida e carreira.

Ao Edmo por todo apoio e conselhos que foram de extrema importância.

À Coordenação de Aperfeiçoamento de Pessoal de Nível Superior (CAPES) pela concessão de bolsa.

Ao Convênio Vale-USP-BNDES pelo suporte financeiro. 
"Missão dada é missão cumprida."

Capitão Nascimento 


\section{RESUMO}

OISHI, B. O. Estudo da capacidade de sorção de cobre por Pseudomonas putida sp. em reator. 2014. 126 f. Tese (Doutorado em Biotecnologia) - Instituto de Ciências Biomédicas, Universidade de São Paulo, São Paulo, 2014.

Bactérias aclimatadas a cobre foram isoladas a partir de amostras de solo e água coletadas na região da Mina de Sossego (Vale, Carajás, PA). Pseudomonas putida sp. foi escolhida, pois, apresentou a maior capacidade sortiva de $\mathrm{Cu}^{2+}, \mathrm{Q}=48 \mathrm{mg} / \mathrm{g}$. $\mathrm{O}$ cultivo em regime de batelada, meio mineral, com glicerol como fonte de carbono, resultou fator de conversão de glicerol a células, $Y_{X / S}$, de $0,49 \mathrm{~g} / \mathrm{g}$ e velocidade específica máxima de crescimento, $\mu_{\max }$, de $0,11 \mathrm{~h}^{-1}$. Alta concentração celular, 90 $\mathrm{g} / \mathrm{L}$, foi alcançada em cultivos em regime de batelada alimentada. Promoveu-se sorção de cobre pelas células, por meio de adição contínua ou em pulsos, de solução de $\mathrm{CuSO}_{4}$. A maior sorção específica de cobre, $\mathrm{Q}$, de $30\left(\mathrm{mg} \mathrm{de} \mathrm{Cu}^{2+} / \mathrm{g}\right.$ de células), foi verificada na adição por pulsos. Fotos de MET da bactéria na ausência e presença de $\mathrm{Cu}^{2+}$ mostram acúmulo de cobre na membrana e internamente, caracterizando biossorção e bioacumulação.

Palavras-chave: Pseudomonas. Biorremediação. Cobre. Reatores bioquímicos. 


\begin{abstract}
OISHI, B. O. Study of Pseudomonas putida sp. cooper sorption capacity in bioreactor. 2014. 126 p. Ph.D. thesis (Biotechnology). - Instituto de Ciências Biomédicas, Universidade de São Paulo, São Paulo, 2014.

Bacteria acclimated to copper were isolated from soil and water samples collected in Mina de Sossego (Vale, Carajás, PA). Pseudomonas putida sp. was chosen as it had the highest sorptive capacity for $\mathrm{Cu}^{2+}, \mathrm{Q}=48 \mathrm{mg} / \mathrm{g}$. The fed-batch culture in mineral medium with glycerol as the carbon source resulted in a glycerol-to-cell conversion factor, $Y_{X / S}$ of $0.49 \mathrm{~g} / \mathrm{g}$ and maximum specific growth rate, $\mu_{\max }$ of $0.11 \mathrm{~h}^{-1}$. High cell concentration, $90 \mathrm{~g} / \mathrm{L}$, was achieved in cultures in fed-batch regimen. Cooper sorption by cells was promoted, by continuous or pulse addition of $\mathrm{CuSO}_{4}$ solution. The highest specific copper sorption, $\mathrm{Q}, 30\left(\mathrm{mg} \mathrm{Cu}^{+2} / \mathrm{g}\right.$ of cells) was seen with the addition by pulses. TEM photos of the bacteria in the absence and presence of $\mathrm{Cu}^{+2}$ show copper accumulation in the membrane and internally, featuring biosorption and bioaccumulation.
\end{abstract}

Keywords: Pseudomonas. Bioremediation. Cooper. Bioreactors. 


\section{LISTA DE ILUSTRAÇÕES}

Figura 1 - Evolução da Produção de Biodiesel

Figura 2 - Via metabólica de assimilação de glicerol por leveduras e bactérias 35

Figura 3 - Imagens da Mina de Sossego da VALE. A: imagem aérea (Google Earth); B: Foto da cava da Mina e C: Foto da lagoa de rejeitos do processamento do minério 41

Figura 4 - Reator modelo Labfors 5 utilizado nos cultivos 47

Figura 5 - Aspersor em Formato de "L" 48

Figura 6 - Sistema externo de filtração de fibra oca acoplado ao reator 49

Figura 7 - Crescimento celular nos meios de cultivo TSM, Ramsay e MJS, a partir de amostras líquidas (1) e de solo (2) da região de Mina de Sossego (Carajás, PA).

Figura 8 - Perfil de migração dos produtos de PCR da região do 16S rDNA de sete isolados de amostra ambiental (1 a 3, correspondendo de $\mathrm{E}$ a G, respectivamente) após eletroforese em gel de agarose $0,8 \%$ coradas com brometo de etídeo. P: padrão de peso molecular 100 pb (Fermentas).... 55

Figura 9 - Crescimento celular de Pseudomonas putida sp nos meios de cultivo Ramsay 2006-2, 2006-1, M63, M9 e TSM 63

Figura 10 - Concentração de células e de glicose no cultivo da Pseudomonas putida em meio sintético Ramsay 2006-2

Figura 11 - $\operatorname{Ln}\left(X / X_{0}\right)$ em função do tempo, no cultivo de Pseudomonas putida sp. em meio Ramsay 2006-2 acrescido de glicose.

Figura 12 - Regressão linear de $\operatorname{Ln}\left(X / X_{0}\right)$ em função do tempo, no intervalo entre 9 e 15h, no cultivo de Pseudomonas putida sp. em meio Ramsay 2006-2 ... 65

Figura 13 - Concentração de células e de glicerol no cultivo de Pseudomonas putida sp em meio sintético Ramsay 2006-2 66

Figura 14 - $\operatorname{Ln}\left(X / X_{0}\right)$ em função do tempo, no cultivo de Pseudomonas putida sp. em meio Ramsay 2006-2 acrescido de glicerol 
Figura 15 - Regressão linear de $\operatorname{Ln}\left(X / X_{0}\right)$ em função do tempo, no intervalo entre 27 e 33h, no cultivo de Pseudomonas putida sp. em meio Ramsay 2006-2 acrescido de glicerol

Figura 16 - Concentração de células e glicerol no cultivo de Pseudomonas putida sp. em meio sintético MM acrescido de glicerol.

Figura 17 - $\operatorname{Ln}\left(X / X_{0}\right)$ em função do tempo, no cultivo de Pseudomonas putida sp. em meio MM acrescido de glicerol

Figura 18 - Regressão linear de $\operatorname{Ln}\left(X / X_{0}\right)$ em função do tempo, no intervalo entre 3 e $13 \mathrm{~h}$, no cultivo de Pseudomonas putida sp. em meio MM acrescido de glicerol 69

Figura 19 - Sorção de cobre em Pseudomonas putida sp. em função do tempo, a 30 ${ }^{\circ} \mathrm{C}$, em água ultra-pura em $\mathrm{pH} 5$ 70

Figura 20 - Sorção de cobre para Pseudomonas putida sp. em diferentes concentrações de cobre. Ce: concentração de metal em equilíbrio na solução; Qe: massa de metal adsorvida por massa de células seca...... 71

Figura 21 - Concentração de células e glicerol em função do tempo de cultivo de Pseudomonas putida sp. em meio MM-HCD com glicerol, regime de batelada - Ensaio B1.

Figura 22 - Regressão linear de $\operatorname{Ln}\left(X / X_{0}\right)$ em função do tempo no intervalo entre 3 e 16h, no cultivo de Pseudomonas putida sp. em meio MM-HCD com glicerol - Ensaio B1

Figura 23 - Rota Metabólica do consumo de glicerol (Fonte: Sítio Keeg Pathway) . 74

Figura 24 - Concentração de células e glicerol em função do tempo de cultivo de Pseudomonas putida sp. em meio MM-HCD com glicerol, regime de batelada alimentada - Ensaio FB1

Figura 25 - Regressão linear de $\operatorname{Ln}\left(X / X_{0}\right)$ em função do tempo de cultivo para a Pseudomonas putida sp. no cultivo em batelada alimentada por pulsos Ensaio FB1 
Figura 26 - Regressão linear com a linha de tendência de $\operatorname{Ln}\left(X / X_{0}\right)$ para a

Pseudomonas putida sp. no cultivo em batelada alimentada utilizando glicerol - Ensaio FB1

Figura 27 - Concentração de lactato, células e glicerol em função do tempo de cultivo de Pseudomonas putida sp. em meio MM-HCD com glicerol, no cultivo em regime de batelada alimentada por pulsos - Ensaio FB1. 78

Figura 28 - Concentração de células e glicerol em função do tempo de cultivo de Pseudomonas putida sp. em meio MM-HCD com glicerol, na etapa inicial em regime de batelada simples do Ensaio FB2. 79

Figura 29 - Concentração de glicerol em função do tempo de cultivo de Pseudomonas putida sp. em meio MM-HCD com glicerol, no regime de batelada alimentada por pulsos - Ensaio FB2.

Figura 30 - Massa de células, $\mathrm{x}$, em função do tempo de cultivo de Pseudomonas putida sp. em meio MM-HCD com glicerol, regime de batelada alimentada - Ensaio FB2. 80

Figura 31 - Concentração de células e glicerol em função do tempo de cultivo de Pseudomonas putida sp. em meio MM-HCD com glicerol, regime de batelada - Ensaio BFA1

Figura 32 - Concentração de células e glicerol em função do tempo de cultivo de Pseudomonas putida sp. em meio MM-HCD com glicerol, regime de batelada - Ensaio BFA2

Figura 33 - Concentração de células e glicerol em função do tempo de cultivo de Pseudomonas putida sp. em meio MM, regime de batelada simples, com adição de solução de sulfato de cobre, 74,16 mg/L de $\mathrm{Cu}^{2+}$, ao final da fase logarítmica - Ensaio BA1

Figura 34 - Concentração de células e glicerol em função do tempo de cultivo de Pseudomonas putida sp. em meio MM, regime de batelada simples, com adição de solução de sulfato de cobre, $76,54 \mathrm{mg} / \mathrm{L}$ de $\mathrm{Cu}^{2+}$, na metade da fase logarítimica - Ensaio BA2 
Figura 35 - Ensaio 1: Massa de células, $x$, e glicerol em função do tempo de cultivo de Pseudomonas putida sp. em regime de batelada alimentada sob vazão exponencial seguido de sorção de cobre

Figura 36 - Ensaio 1: Percentual de $\mathrm{CO}_{2}$ no gás de saída do reator em função do tempo de cultivo de Pseudomonas putida sp. em regime de batelada alimentada sob vazão exponencial seguido de sorção de cobre

Figura 37 - Ensaio 1: Regressão linear de $\operatorname{Ln}\left(X / X_{0}\right)$ em função do tempo de cultivo de Pseudomonas putida sp. em regime de batelada alimentada sob vazão exponencial seguido de sorção de cobre

Figura 38 - Ensaio 1: Regressão linear com a linha de tendência de $\operatorname{Ln}\left(X / X_{0}\right)$ no cultivo com alimentação exponencial de glicerol e nutrientes para o intervalo de $3-28,5$ horas no ensaio de Pseudomonas putida sp. em regime de batelada alimentada sob vazão exponencial seguido de sorção de cobre

Figura 39 - Ensaio 2: Massa de células, $\mathrm{x}$, e glicerol em função do tempo de cultivo de Pseudomonas putida sp. em regime de batelada alimentada sob vazão exponencial seguido de sorção de cobre

Figura 40 - Ensaio 2: Regressão linear de $\operatorname{Ln}\left(X / X_{0}\right)$ em função do tempo de cultivo de Pseudomonas putida sp. em regime de batelada alimentada sob vazão exponencial seguido de sorção de cobre.

Figura 41 - Ensaio 2: Regressão linear com a linha de tendência de $\operatorname{Ln}\left(X / X_{0}\right)$ no cultivo com alimentação exponencial de glicerol e nutrientes para o intervalo de $3-33,5$ horas no ensaio de Pseudomonas putida sp. em regime de batelada alimentada sob vazão exponencial seguido de sorção de cobre

Figura 42 - Ensaio 2: Massa de células, $x$, em função do tempo de cultivo de Pseudomonas putida sp. em regime de batelada alimentada sob vazão exponencial seguido de sorção de cobre

Figura 43 - Ensaio 3: Massa de células, x, e glicerol em função do tempo de cultivo de Pseudomonas putida sp. em regime de batelada alimentada sob vazão exponencial seguido de sorção de cobre 99 
Figura 44 - Ensaio 3: Regressão linear de $\operatorname{Ln}\left(X / X_{0}\right)$ em função do tempo de cultivo de Pseudomonas putida sp. em regime de batelada alimentada sob vazão exponencial seguido de sorção de cobre. 100

Figura 45 - Ensaio 3: Regressão linear com a linha de tendência de $\operatorname{Ln}\left(X / X_{0}\right)$ no cultivo com alimentação exponencial de glicerol e nutrientes para o intervalo de 3 - 36 horas no ensaio de Pseudomonas putida sp. em regime de batelada alimentada sob vazão exponencial seguido de sorção de cobre

Figura 46 - Ensaio 3: Massa de células, $x$, em função do tempo de cultivo de Pseudomonas putida sp. em regime de batelada alimentada sob vazão exponencial seguido de sorção de cobre.

Figura 47 - Imagem obtida por microscopia de transmissão eletrônica da Pseudomonas putida sp., ampliada 40.000 vezes, em amostragem realizada antes da adição de cobre, correspondente às $35,5 \mathrm{~h}$ do cultivo no Ensaio 3 105

Figura 48 - Imagem obtida por microscopia de transmissão eletrônica da Pseudomonas putida sp., ampliada 40.000 vezes, em amostra correspondente ao pulso de número 15 , às 65,5 h do cultivo no Ensaio 3

Figura 49 - Imagem obtida por microscopia de transmissão eletrônica da Pseudomonas putida sp., ampliada 40.000 vezes, em amostra correspondente ao pulso de número 21 , às 77,5 h do cultivo no Ensaio 3

Figura 50 - Imagem obtida por microscopia de transmissão eletrônica da Pseudomonas putida sp., ampliada 40.000 vezes, em amostra correspondente ao pulso de número 21 , às 77,5 h do cultivo no Ensaio 3 


\section{LISTA DE TABELAS}

Tabela 1 - Concentração máxima de metal permitida nos efluentes segundo o CONAMA em resolução de 2008

Tabela 2 - Vantagens e desvantagens dos métodos tradicionais de tratamento de efluentes contendo metais pesados.

Tabela 3 - Interações de Microrganismos e metais. 29

Tabela 4 - Sorção de Cobre por bactérias 36

Tabela 5 - Iniciadores utilizados nas reações de PCR (Reação de Polimerização em Cadeia) e clonagem 43

Tabela 6 - Condições de cultivo em meio solidificado no isolamento de Bactérias de amostras da área de solo ou líquido da Mina de Sossego (Carajás, PA) 53

Tabela 7 - Similaridade dos clones obtidos com o banco de dados do Genbank.... 56

Tabela 8 - Resultados de Crescimento para Pseudomonas putida sp. em Meio Sintético TSM com Glicose $(0,50 \% \mathrm{p} / \mathrm{v})$ ou Glicerol $(0,50 \% \mathrm{p} / \mathrm{v})$ 57

Tabela 9 - Crescimento celular de Pseudomonas putida sp. em Meio Sintético TSM com Glicose $(0,50 \%$ p/v) e diferentes concentrações do tampão TRIS ... 58

Tabela 10 - Crescimento celular de Pseudomonas putida sp. em Meio Sintético TSM contendo ureia, Glicose $(0,50 \% \mathrm{p} / \mathrm{v})$ ou Glicerol $(0,50 \% \mathrm{p} / \mathrm{v})$ 59

Tabela 11 - Crescimento de Pseudomonas putida sp. em Meio Sintético M9-ureia com Glicose $(0,50 \% \mathrm{p} / \mathrm{v})$ ou Glicerol $(0,50 \% \mathrm{v} / \mathrm{v})$ 59

Tabela 12 - Crescimento de Pseudomonas putida sp. em Meio Sintético M63 com Glicose $(0,50 \% \mathrm{p} / \mathrm{v})$ ou Glicerol $(0,50 \% \mathrm{p} / \mathrm{v})$

Tabela 13 - Crescimento de Pseudomonas putida sp. em Meio Ramsay 2006-1 com Glicose $(0,50 \% \mathrm{p} / \mathrm{v})$

Tabela 14 - Crescimento de Pseudomonas putida sp. em Meio Ramsay 2006-1 e Ramsay 2006-2 com Glicose (0,50\% p/v) e Glicerol (0,50\% p/v) - 24 horas

Tabela 15 - Crescimento de Pseudomonas putida sp. em Meio Ramsay 2006-1 e Ramsay $2006-2$ com Glicerol $(0,50 \%$ p/v $)-48$ horas 
Tabela 16 - Resultados de Sorção de cobre pela Pseudomonas putida sp utilizada neste trabalho e dados de literatura.

Tabela 17 - Resultados de Adsorção - Ensaio BFA1

Tabela 18 - Massa de cobre sorvida por massa de células, $Q$, em função do meio líquido da suspensão de Pseudomonas putida sp.

Tabela 19 - Massa de cobre sorvida por massa de células, Q, por Pseudomonas putida sp. previamente cultivada em regime de batelada e submetida a filtração tangencial - Ensaio BFA2

Tabela 20 - Resultados de Sorção de Cobre para Pseudomonas putida sp. em crescimento em meio mineral, regime de batelada simples, adição de

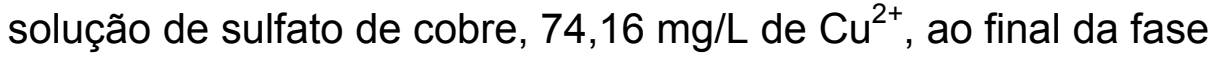
logarítmica - Ensaio BA1

Tabela 21 - Resultados de Sorção de Cobre para Pseudomonas putida sp. em crescimento em meio mineral, regime de batelada simples, com única adição de solução de sulfato de cobre, $76,54 \mathrm{mg} / \mathrm{L}$ de $\mathrm{Cu}^{2+}$, na metade da fase logarítmica - Ensaio BA2

Tabela 22 - Valores de Q (mg/g) no cultivo do Ensaio 1 com alimentação exponencial de glicerol e nutrientes 93

Tabela 23 - Ensaio 2: Concentração de $\mathrm{Cu}^{2+}$ acumulada logo após cada pulso ..... 96

Tabela 24 - Adsorção de Cobre no Ensaio 2 ........................................................ 98

Tabela 25 - Ensaio 3: Concentração de $\mathrm{Cu}^{2+}$ acumulada logo após cada pulso ... 102 Tabela 26 - Adsorção de Cobre no Ensaio 3 104 


\section{LISTA DE ABREVIATURAS E SIGLAS}

\begin{tabular}{ll} 
ANP & Agência Nacional de Petróleo \\
ATP & Adenosina trifosfato \\
BNDES & Banco Nacional de Desenvolvimento \\
Ce & Concentração de metal em equilíbrio na solução \\
CNPE & Conselho Nacional de Política Energética \\
CONAMA & Conselho Nacional de Meio Ambiente \\
CSTR & Continuous Stirred Tank Reactor \\
DNA & Ácido desoxirribonucleico \\
DO & Densidade óptica \\
EDTA & Ácido etilenodiamino tetra-acético \\
EPS & Polissacarídeos extracelulares secretados \\
g/g & Grama de célula por grama de substrato \\
g/L & Grama por litro \\
GOD-POD & Glicose oxidase peroxidase \\
h & Horas \\
HPLC & Cromatografia Líquida de Alto Desempenho \\
ICP-AES & Espectrometria de emissão atômica por plasma acoplado \\
& indutivamente \\
IUPAC & União Internacional de Química Pura e Aplicada \\
k & Constante de Langmuir \\
kg & Quilograma \\
L & Litro \\
LB & Luria-Bertani \\
M & Molar \\
min & Minutos \\
MIT & Sistema de incorporação de magnésio \\
mL & Mililitro \\
mM & Milimolar \\
NA & Ácido nonânico \\
ng & Nanograma \\
nm & Nanômetro \\
\hline a &
\end{tabular}




\begin{tabular}{|c|c|}
\hline PCR & Reação em Cadeia da Polimerase \\
\hline PHA & Polihidroxialcanoato \\
\hline PHB & Polihidroxibutirato \\
\hline pM & Picomolar \\
\hline $\mathrm{pO}_{2}$ & Pressão parcial de oxigênio dissolvido na fase líquida \\
\hline ppm & Parte por milhão \\
\hline $\mathrm{p} / \mathrm{v}$ & Peso por volume \\
\hline Q & Massa de cobre sorvida por massa de células secas \\
\hline Qe & Massa de metal adsorvida por massa de células secas \\
\hline rDNA & Ácido desoxirribonucleico ribossomal \\
\hline RPM & Rotações por minuto \\
\hline rRNA & Ácido ribonucleico ribossomal \\
\hline SDS & Dodecil sulfato de sódio \\
\hline U & Unidade \\
\hline USP & Universidade de São Paulo \\
\hline V & Volt \\
\hline $\mathrm{v} / \mathrm{v}$ & Volume por volume \\
\hline vvm & Volume de gás por volume de meio por minuto \\
\hline $\mathrm{x}$ & Concentração de células secas \\
\hline $\mathrm{x}$ & Massa de células secas \\
\hline$Y_{X / S}$ & Fator de conversão de substrato a célula \\
\hline$\mu$ & Velocidade específica de crescimento $\left(h^{-1}\right)$ \\
\hline$\mu \mathrm{g}$ & Micrograma \\
\hline$\mu \mathrm{L}$ & Microlitro \\
\hline$\mu \mathrm{M}$ & Micromolar \\
\hline$\mu_{\max }$ & Velocidade específica de crescimento máxima $\left(\mathrm{h}^{-1}\right)$ \\
\hline
\end{tabular}




\section{LISTA DE SÍMBOLOS}

$\begin{array}{ll}\mathrm{Co}^{2+} & \text { Ín cobalto bivalente } \\ \mathrm{CO}_{2} & \text { Dióxido de carbono } \\ \mathrm{Cu}^{2+} & \text { Ín cobre bivalente } \\ \mathrm{Fe}^{2+} & \text { Ín ferro bivalente } \\ \mathrm{Mg}^{2+} & \text { Ín magnésio bivalente } \\ \mathrm{Mn}^{2+} & \text { Ín manganês bivalente } \\ \mathrm{Ni}^{2+} & \text { Íon níquel bivalente } \\ \mathrm{Zn}^{2+} & \text { Ín zinco bivalente }\end{array}$




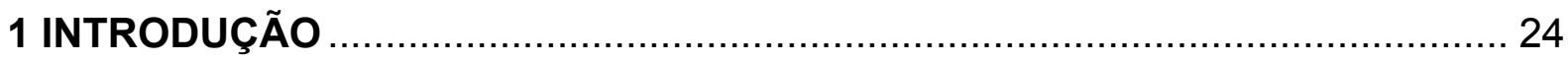

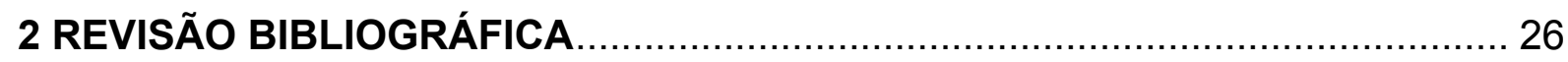

2.1 Contaminação do meio ambiente aquático com metais pesados ................ 26

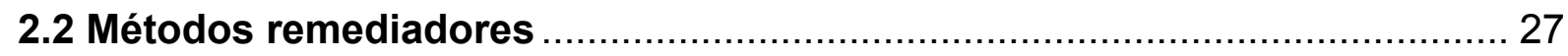

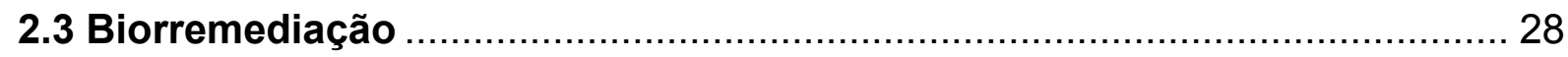

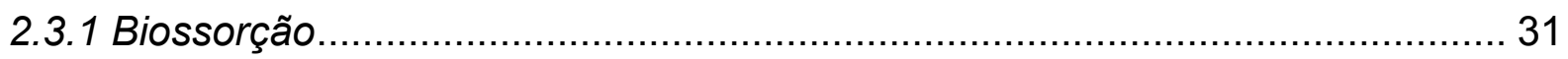

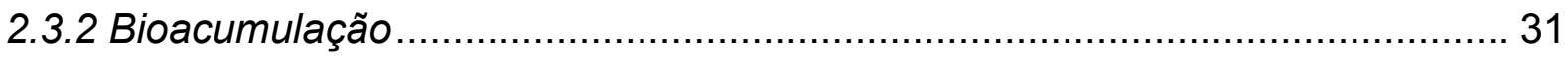

2.4 Isolamento e Identificação de microrganismos resistentes a metais

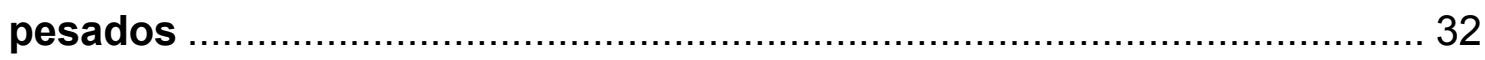

2.5 Condições de cultivo para seleção de linhagens remediadoras de metal .. 33

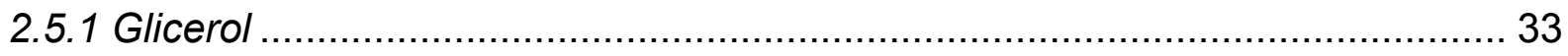

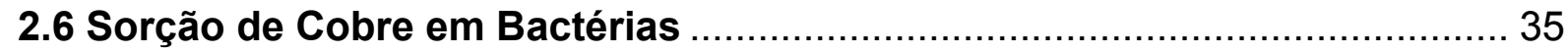

2.7 Cultivo de Alta Densidade Celular para bactérias do gênero Pseudomonas 36

3 OBJETIVOS

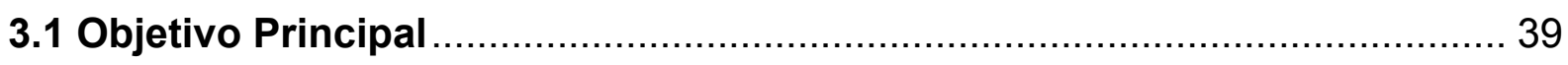

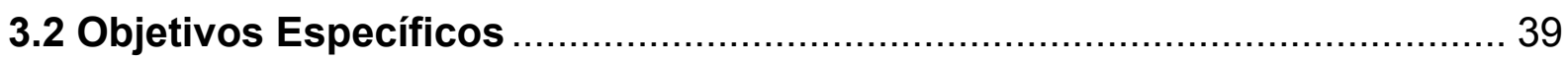

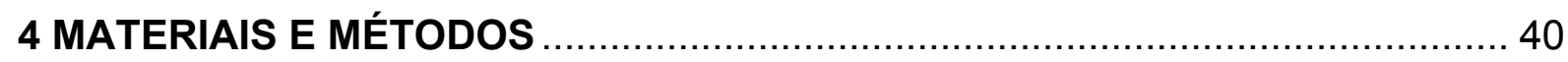

4.1 Mina de Sossego da Vale em Carajás - PA ................................................... 40

4.2 Isolamento de bactérias da Mina de Sossego ........................................... 41

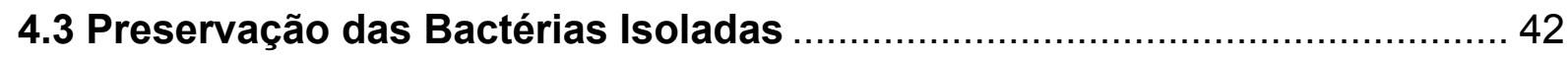

4.4 Identificação dos isolados bacterianos por meio do sequenciamento do

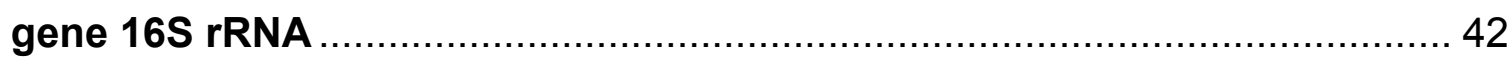

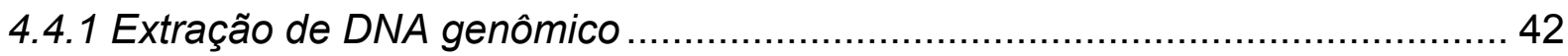

4.4.2 Análise eletroforética de DNA em gel de agarose e purificação de fragmentos

4.4.3 Reações de PCR (Reação de Polimerização em Cadeia) e clonagem ............ 42

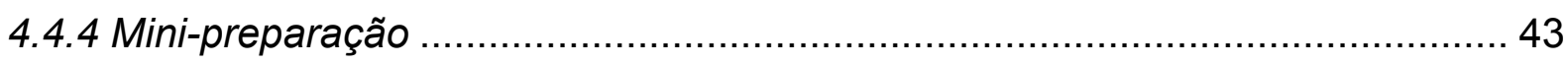

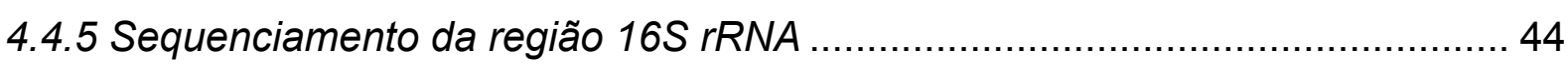

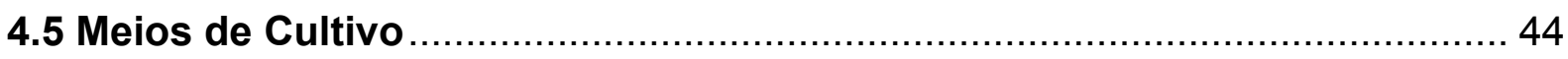

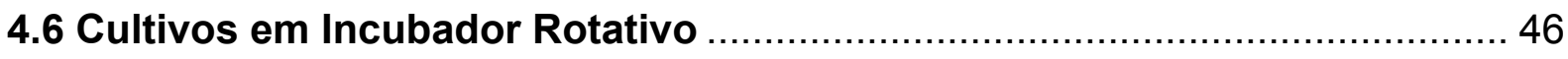

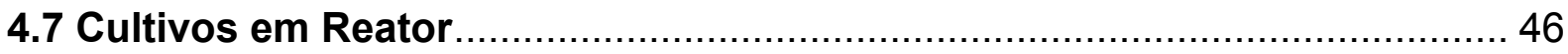


4.8 Preparo de Inóculo para os Cultivos em Reator 48

4.9 Sistema Externo de Filtração Tangencial acoplado ao Reator ..................... 48

4.10 Função de Vazão de Alimentação Exponencial do Reator ........................ 49

4.11 Sorção de Cobre pelas bactérias isoladas: Isoterma de Langmuir ........... 50

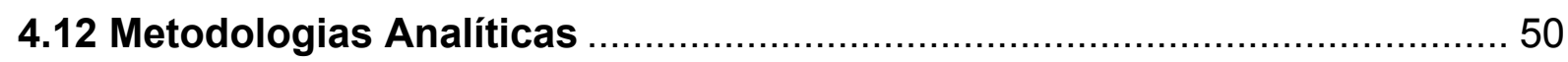

5 RESULTADOS E DISCUSSÃO

5.1 Isolamento de linhagens selvagens resistentes a cobre e níquel............... 52

5.2 Identificação das linhagens por análise de 16S rRNA .................................53

5.3 Avaliação de meios de cultivo para crescimento do isolado bacteriano identificado como Pseudomonas putida sp............................................... 57

5.3.1 Meio sintético TSM com glicose $(0,50 \% \mathrm{p} / \mathrm{v})$ ou glicerol $(0,50 \% \mathrm{v} / \mathrm{v}) \ldots \ldots \ldots \ldots . . .57$

5.3.2 Meio sintético TSM com glicose a $0,50 \%(p / v)$ e variadas concentrações de TRIS. 58

5.3.3 Meio sintético TSM com ureia, glicerol $(0,50 \% \mathrm{v} / \mathrm{v})$ ou glicose $(0,50 \% \mathrm{p} / \mathrm{v})$.... 58

5.3.4 Meio sintético M9 com ureia, glicerol $(0,50 \% \mathrm{v} / \mathrm{v})$ ou glicose $(0,50 \% \mathrm{p} / \mathrm{v})$....... 59

5.3.5 Meio sintético M63 com glicerol $(0,50 \% \mathrm{p} / \mathrm{v})$ ou glicose $(0,50 \% \mathrm{p} / \mathrm{v}) \ldots \ldots \ldots \ldots . . . .60$

5.3.6 Meio sintético Ramsay 2006-1 com glicose $(0,50 \% \mathrm{p} / \mathrm{v})$............................... 60

5.3.7 Meio sintético Ramsay 2006-2 contendo glicose $(0,50 \% \mathrm{p} / \mathrm{v})$ e glicerol $(0,50 \%$ $p / v)$

5.3.8 Resumo dos resultados dos cultivos de P. putida sp nos meios Ramsay, M63, M9 e TSM

5.3.9 Cinética do Crescimento em meio sintético Ramsay 2006-2 com glicose $(0,50 \% \mathrm{p} / \mathrm{v})$

5.3.10 Cinética do Crescimento em meio sintético Ramsay 2006-2 com glicerol $(0,50 \% \mathrm{p} / \mathrm{v})$ 66

5.3.11 Cinética do Crescimento em meio sintético MM com glicerol $(0,50 \%$ p/v).... 68

5.4 Sorção de Cobre e Isoterma de Langmuir .................................................. 70

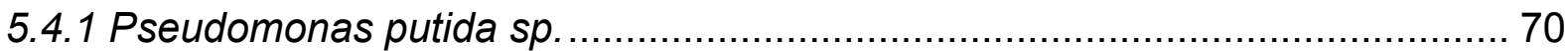

5.4.2 Resultados de sorção de Pseudomonas putida sp. e dados de literatura ....... 71

5.5 Cultivo em Regime de Batelada - Ensaio B1 …................................... 72

5.6 Cultivos de Pseudomonas putida sp. em Regime de Batelada Alimentada por Pulsos para Alta Densidade Celular................................................ 74

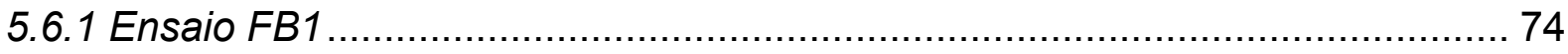

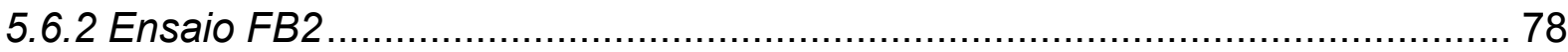


5.7 Cultivos em Regime de Batelada com Sistema de Filtração e Adição Contínua de Cobre

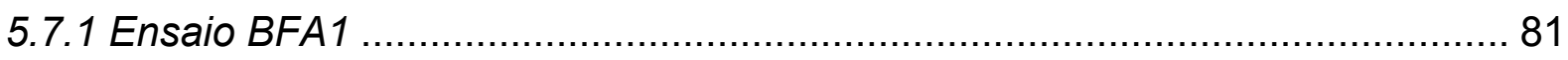

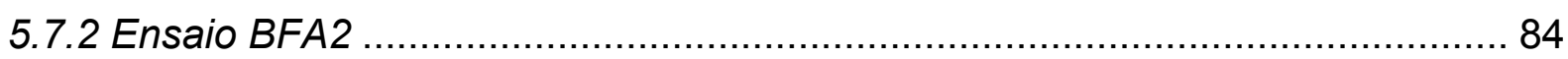

5.8 Cultivos de Pseudomonas putida sp. em Regime de Batelada e Sorção de Cobre em Diferentes Estágios do Crescimento - Ensaios BA1 e BA2 ..... 86

5.9 Cultivos de Pseudomonas putida sp. em Regime de Batelada Alimentada sob Vazão Exponencial, seguidos de Sorção de Cobre ........................... 89

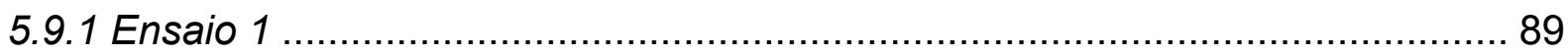

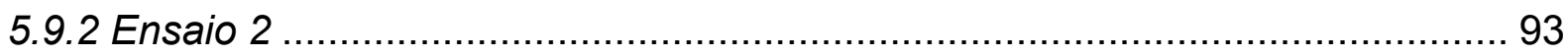

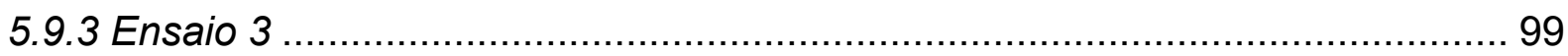

5.9.4 Resumo da Sorção de Cobre em Pseudomonas putida sp......................... 108

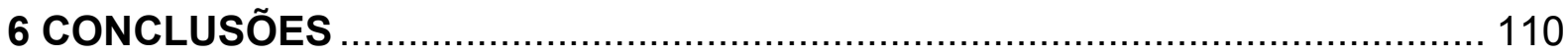

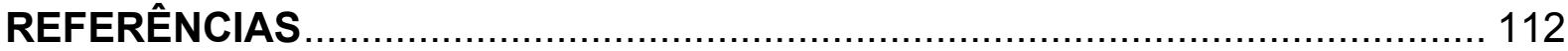

APÊNDICE - Estudo de Transferência de Oxigênio no Reator da Infors Modelo Labfors 5 


\section{INTRODUÇÃO}

A poluição do meio ambiente com metais é uma das mais severas agressões ambientais, dado que alguns metais são tóxicos aos seres vivos e são acumulados no solo e cursos d'água por não serem biodegradáveis.

O presente trabalho de Doutorado insere-se no tema biorremediação de ambientes contaminados com metais e foi realizado no âmbito do convênio assinado entre a Vale, a USP e o BNDES (Banco Nacional de Desenvolvimento) em 2011, especificamente para a região da Mina de Sossego localizada no município de Canaã dos Carajás (PA).

O convênio tem por objetivo desenvolver processos para a biorremediação do solo e águas da área da Mina de Sossego, baseados no emprego de microrganismos autóctones, isto é, isolados na região. Além disso, estuda-se a viabilidade de lixiviação bacteriana do rejeito do minério processado para posterior recuperação desses metais, bem como daqueles disseminados no meio ambiente.

A opção por uma biorremediação é devida aos baixos teores dos metais dispersos no ambiente e no rejeito da mineração, pois, do contrário, operações físico-químicas seriam mais efetivas.

Diversos profissionais estão envolvidos neste convênio, a saber: docentes da USP; pesquisadores-doutores contratados pelo Convênio; pós-graduandos; funcionários da Vale de forma indireta através da atuação destes nas plantas piloto que vierem a ser implantadas na Mina de Sossego (Carajás, PA).

Atualmente, as pesquisas conduzidas no Departamento de Engenharia Química da USP, versam sobre $O$ isolamento de bactérias autóctones com capacidade para lixiviação de cobre e o emprego de fungos na biorremediação.

O presente projeto de doutorado teve por objetivo isolar uma bactéria da Mina de Sossego da Vale (Carajás, PA) com elevada capacidade de sorção de cobre e aplica-la em cultivos em reator, em meio sintético, promovendo a sorção de cobre por células viáveis.

O objetivo inicial era realizar o estudo fisiológico da bactéria isolada e selecionada com base na capacidade de sorção de cobre, por meio de cultivos em regime contínuo. Entretanto, os baixos valores de concentração e velocidade específica de crescimento máxima, $\mu_{\max }$, da bactéria selecionada, Pseudomonas putida sp., resultariam em cultivos longos e, possivelmente, sem consequências 
importantes à fisiologia celular, dadas as reduzidas concentrações reais do cobre, optou-se por uma abordagem diferente, que foi a realização de cultivos para alta concentração ou densidade celular e posterior sorção de cobre.

À época do início deste doutoramento, setembro de 2009, o aluno atuava em uma empresa cuja atividade era o desenvolvimento de pesquisas em biopesticidas, razão pela qual, o projeto inicial versava sobre o desenvolvimento do cultivo de Bacillus thuringiensis em meio semi-sólido. A mudança de projeto ocorreu em dezembro de 2011, do que resulta que esta tese foi desenvolvida a partir de dezembro de 2011, isto é, no intervalo de apenas 32 meses. 


\section{REVISÃO BIBLIOGRÁFICA}

\subsection{Contaminação do meio ambiente aquático com metais pesados}

Com a expansão e sofisticação dos setores produtivos nas últimas décadas aumentou a demanda por água para processos industriais e, consequentemente, a quantidade e complexidade da composição dos resíduos líquidos, que podem conter metais pesados, os quais são resultantes de atividades industriais, agrícolas e de mineração (VEGLIO; ESPOSITO; REVERBERI, 2003). Dentre os metais pesados presentes nos resíduos, o elemento cobre, presente nas várias atividades supracitadas, apresenta elevado potencial de contaminação do solo e da água (ANDREAZZA, 2009).

Há controvérsia sobre a definição do termo "metais pesados", sendo que a definição mais aceita é aquela que considera os elementos químicos de densidade igual ou maior a $5 \mathrm{~g} / \mathrm{cm}^{3}$ (NIES, 1999; PIVELI; KATO, 2005; ROANE; PEPPER, 2000).

A toxicidade dos metais pesados está relacionada à concentração do íon em um dado organismo. O cobre é um micronutriente essencial para todos os seres vivos, porém, em concentrações acima das necessidades fisiológicas, causa danos (NIES, 1999), tais como bloqueio de reações bioquímicas, por exemplo, a inativação enzimática, interferência nos processos de transcrição e tradução de genes e lise celular (PINO, 2005; VULLO, 2003), além de câncer em seres humanos (ANDREAZZA, 2009). Para plantas, fungos e bactérias, concentrações elevadas de cobre promovem pressão de seleção, sobrevivendo somente os organismos resistentes.

As máximas concentrações de metais pesados permitidas em efluentes foram estabelecidas pelo Conselho Nacional de Meio Ambiente (CONAMA, Ministério do Meio Ambiente) na Resolução de número 397 de 2008 e estão listadas na Tabela 1. Tais concentrações foram definidas de modo a minimizar os efeitos deletérios sobre o meio ambiente (LEMOS et al., 2008). 
Tabela 1 - Concentração máxima de metal permitida nos efluentes segundo o CONAMA em resolução de 2008

\begin{tabular}{cc}
\hline Metal & $\begin{array}{c}\text { Valor Máximo } \\
\text { (mg/L) }\end{array}$ \\
\hline Boro total & 5,00 \\
Cádmio total & 0,20 \\
Chumbo total & 0,50 \\
Cobre dissolvido & $\mathbf{1 , 0 0}$ \\
Cromo hexavalente & 0,10 \\
Cromo trivalente & 1,00 \\
Estanho total & 4,00 \\
Ferro dissolvido & 15,00 \\
Manganês dissolvido & 1,00 \\
Mercúrio total & 0,01 \\
Níquel total & 2,00 \\
Prata total & 0,10 \\
Selênio total & 0,30 \\
Zinco total & 5,00
\end{tabular}

Fonte: Conama, 2008

\subsection{Métodos remediadores}

As operações tradicionalmente utilizadas na remoção de metais pesados são as seguintes: precipitação química e filtração, oxidação e redução, tratamento eletroquímico, osmose reversa, troca iônica, adsorção e evaporação. As desvantagens e vantagens de cada operação estão listadas na Tabela 2. 
Tabela 2 - Vantagens e desvantagens dos métodos tradicionais de tratamento de efluentes contendo metais pesados.

\begin{tabular}{|c|c|c|}
\hline Método & Desvantagem & Vantagem \\
\hline $\begin{array}{l}\text { Precipitação química e } \\
\text { filtração }\end{array}$ & $\begin{array}{c}\text { Para concentrações altas } \\
\text { Separação difícil e não muito } \\
\text { efetiva } \\
\text { Produz resíduos tóxicos }\end{array}$ & $\begin{array}{l}\text { Sistema simples } \\
\text { Baixo custo }\end{array}$ \\
\hline $\begin{array}{c}\text { Oxidação e redução } \\
\text { química }\end{array}$ & Requer agentes químicos & Mineralização \\
\hline Tratamento eletroquímico & $\begin{array}{c}\text { Para altas concentrações } \\
\text { Custo elevado }\end{array}$ & $\begin{array}{c}\text { Possibilita a recuperação } \\
\text { dos metais }\end{array}$ \\
\hline Osmose reversa & $\begin{array}{l}\text { Altas pressões } \\
\text { Custo elevado }\end{array}$ & $\begin{array}{l}\text { Efluente puro (para } \\
\text { reciclagem) }\end{array}$ \\
\hline Troca iônica & $\begin{array}{l}\text { Sensível à presença de partículas } \\
\text { Resinas de custo elevado }\end{array}$ & $\begin{array}{l}\text { Possível recuperação do } \\
\text { metal }\end{array}$ \\
\hline Adsorção & Não efetivo para alguns metais & $\begin{array}{c}\text { Sorventes convencionais } \\
\text { (carvão) }\end{array}$ \\
\hline Evaporação & $\begin{array}{l}\text { Alta custo energético } \\
\text { Custo elevado } \\
\text { Produz efluente }\end{array}$ & $\begin{array}{l}\text { Obtenção do efluente } \\
\text { puro }\end{array}$ \\
\hline
\end{tabular}

Fonte: Adaptado de Volesky, 2001 e Zouboulis; Loukidou; Matis, 2004.

Devido a custos elevados, dificuldades técnicas de implantação das operações físico-químicas e o fato de que várias destas operações são efetivas apenas para efluentes contendo concentrações de metais acima de $100 \mathrm{mg} / \mathrm{L}$, a busca por alternativas economicamente viáveis e ecologicamente corretas foi intensificada nos últimos anos. O uso de microrganismos para biorremediação se mostra vantajoso, principalmente pelos baixos custos quando comparado às operações físico-químicas convencionais (GAVRILESCU, 2004; LEMOS et. al, 2008; VOLESKY, 2001; ZOUBOULIS; LOUKIDOU; MATIS, 2004).

\subsection{Biorremediação}

Biorremediação é a denominação genérica dada a processos biotecnológicos nos quais plantas ou microrganismos são utilizados para remover ou reduzir (remediar) poluentes do meio ambiente. Processos biotecnológicos de remediação 
têm sido intensamente pesquisados, pois, tratam-se de alternativa viável às operações fisico-químicas tradicionais de remediação de ambientes contaminados, tais como solos, águas superficiais e subterrâneas, além de resíduos sólidos e efluentes industriais lançados em aterros ou áreas de contenção (GAYLARDE; BELLINASO; MANFIO, 2005).

A forma como os microrganismos interagem com metais pode ser dividida em imobilização e mobilização. Esta compreende alteração de um estado insolúvel inicial, com os metais na forma de sulfetos ou óxidos metálicos em fase sólida, para um estado solúvel em fase aquosa. Já a imobilização é definida como a passagem desde o estado solúvel em fase aquosa para o estado insolúvel em fase sólida (LEMOS et al., 2008). Ambas as formas de interação entre metal e microrganismos apresentam diferentes mecanismos a seguir resumidos na Tabela 3.

Tabela 3 - Interações de Microrganismos e metais

\begin{tabular}{|c|c|c|}
\hline Interação & Mecanismos & Princípio \\
\hline \multirow{4}{*}{ Mobilização } & Oxirredução & $\begin{array}{l}\text { Metais são oxidados ou reduzidos pelos } \\
\text { microrganismos, aumentando a mobilidade do metal } \\
\text { de acordo com o tipo do metal e seu estado de } \\
\text { oxidação. }\end{array}$ \\
\hline & Acidificação & $\begin{array}{l}\text { Microrganismos secretam prótons resultando na } \\
\text { mobilidade do metal. Sob estas condições, os } \\
\text { prótons se ligam à superfície resultando um } \\
\text { enfraquecimento em ligações críticas, além da } \\
\text { substituição dos íons de metais presentes na } \\
\text { superfície sólida. }\end{array}$ \\
\hline & Complexação & $\begin{array}{l}\text { Ocorre pela formação de complexos por } \\
\text { microrganismos ou a quelação de metais por } \\
\text { agentes que aumentam a mobilidade do metal. São } \\
\text { formados cmplexos na superfície do metal através } \\
\text { da troca de ligantes que polarizam ligações críticas e } \\
\text { facilitam o desligamento do metal da superfície. }\end{array}$ \\
\hline & Alquilação & $\begin{array}{l}\text { Grupos alquilas são enzimaticamente transferido } \\
\text { para o metal e ligados covalentemente. Este } \\
\text { processo geralmente conhecido como "volatilização } \\
\text { de metal", pois os metais apresentam uma } \\
\text { volatilidade maior em comparação com as suas } \\
\text { formas elementares ou iônicas, sendo a metilação é } \\
\text { o melhor processo de alquilação. }\end{array}$ \\
\hline
\end{tabular}




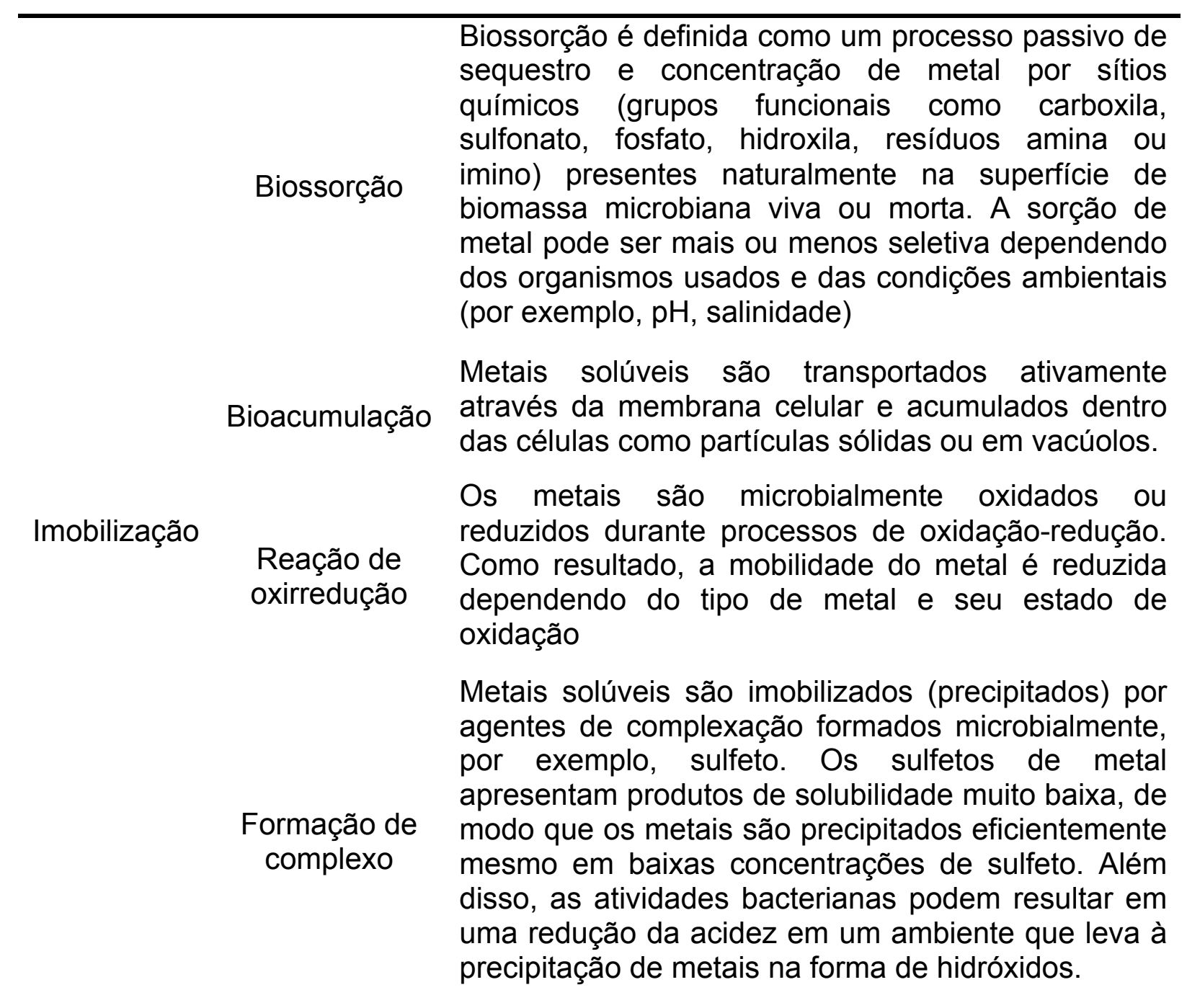

Fonte: Brandl, 2005

Os diversos mecanismos de interação entre metais e microrganismos permitem que estes sejam utilizados em estratégias de remediação de ambientes contaminados por metais pesados, uma vez que resistem a tais ambientes e podem atuar como poderosas ferramentas biológicas na biorremediação. $O$ enfoque principal deste trabalho foi para a biossorção e bioacumulação.

Sorção é um termo geral que inclui adsorção e absorção (acumulação), sendo que a adsorção é o processo de ligação de uma substância em uma superfície ou interface e a absorção é o processo de acumulação pela interpenetração de uma substância em outra fase (PERRY; CHILTON, 1973; WEBER, 1972). 


\subsubsection{Biossorção}

Segundo Volesky et al. (2001), a biossorção pode ser definida como um processo onde se utiliza biomassa vegetal ou microrganismos na retenção, remoção ou recuperação de metais pesados de um ambiente líquido. Outra definição de biossorção, a qual pode ser considerada mais abrangente, foi dada por Veglio e Beolchini (1997) que é a ligação de metais pesados por materiais biológicos, tais como algas, leveduras, fungos e bactérias.

A biossorção é um processo independente do metabolismo catabólico, portanto, pode ocorrer tanto em células vivas como em células mortas, que foi descrita como adsorção ou captação passiva (DONMEZ; AKSU, 1999; KAPOOR; VIRARAGHAVAN; CULLIMORE, 1999).

A biossorção de íons de metais pesados ocorre através de interações fisicoquímicas entre o metal e constituintes da membrana ou parede celular (LEMOS, 2008). Existem diversos grupos químicos presentes nos microrganismos que podem atrair e reter metais, dentre eles, grupos acetamidas da quitina, polissacarídeos estruturais de parede celular de fungos, grupos aminas e fosfatos em ácidos nucléicos, grupos amidas, sulfidrilas e carboxilas em proteínas e grupos hidroxilas em polissacarídeos (SKOWRONSKI; PIRSZEL; SKOWRONSKA, 2001; VOLESKY; HOLAN, 1995).

\subsubsection{Bioacumulação}

A bioacumulação é o processo que corresponde ao transporte dos cátions de metais pesados através da membrana celular, sua acumulação intracelular e formação de compostos organometálicos, sendo, portanto, metabolismo ativo com gasto de energia, em células vivas. (GRAVILESCU, 2004; LEMOS et al., 2008; VOLESKY, 2007). A remoção de íons de metais pesados por este tipo de mecanismo é usualmente mais lenta que o mecanismo de adsorção. Em contrapartida, maiores quantidades de metal podem ser acumuladas dentro das células (GAAD, 2010).

Os íons de metais pesados apresentam duas vias para entrar nas células, sendo uma inespecífica e outra de grande especificidade. A primeira ocorre através de um gradiente quimiosmótico da membrana citoplasmática (transporte passivo). 
Os cátions de metais pesados divalentes, tais como $\mathrm{Mn}^{2+}, \mathrm{Fe}^{2+}, \mathrm{Co}^{2+}, \mathrm{Ni}^{2+}, \mathrm{Cu}^{2+} \mathrm{e}$ $\mathrm{Zn}^{2+}$, são estruturalmente similares ao $\mathrm{Mg}^{2+}$, e podem entrar na célula de forma passiva, em bactérias gram-negativas, pelo sistema de incorporação de magnésio (MIT). (NIES, 1999). A segunda e principal via envolve hidrólise de ATP (transporte ativo) (GRASS et al., 2005; NIES; SILVER, 1995). De maneira geral, as proteínas envolvidas no transporte passivo de íons são expressas constitutivamente pelas células, enquanto a expressão das proteínas de transporte ativo é regulada. Uma vez dentro das células, os íons de metais pesados, em concentrações acima dos limites fisiológicos, causam diversos danos tais como inibição da transcrição, da tradução, da divisão celular e da atividade enzimática.

\subsection{Isolamento e Identificação de microrganismos resistentes a metais pesados}

A grande versatilidade metabólica dos microrganismos possibilita diversas formas de interação entre microrganismos e metais pesados. Assim sendo, torna-se premente a necessidade de isolar microrganismos a partir de áreas contaminadas por metais pesados para a aplicação e estudo de processos biorremediadores para recuperação de tais áreas.

Para a seleção de microrganismos, normalmente são utilizados métodos da microbiologia clássica, tais como os que se valem de meios seletivos que permitam o crescimento de microrganismos cultiváveis e seleção daqueles que sejam altamente resistentes e capazes de imobilizar o metal de interesse (DINU; ANGHEL; JURCOANE, 2011; OLUKOYA et al., 1997; RAJBANSHI, 2008).

As técnicas de biologia molecular tem sido amplamente utilizadas para a identificação de microrganismos, devido a capacidade de identificar sequência genéticas específicas para grupos de microrganismos. A análise de sequências do gene que codifica o 16S rRNA (16S rDNA) tem sido usada para inferir as relações filogenéticas e taxonômicas das bactérias, sendo adotada usualmente para estabelecer limites entre espécies procarióticas (STACKENBRANDT; GOEBEL, 1994). As propriedades que fazem desta região gênica um alvo são adequadas para estudos de diversidade microbiana devido às seguintes características: (i) possui uma distribuição universal em procariotos, (ii) é pouco afetada pela transferência horizontal, (iii) apresenta em sua sequência uma alternância entre regiões mais e 
menos conservadas, permitindo a investigação de um amplo espectro de distâncias filogenéticas, desde o nível de domínio até o nível de espécie (LUDWIG; SCHLEIFER, 1994), (iv) quantidade considerável de informações disponíveis em banco de dados.

\subsection{Condições de cultivo para seleção de linhagens remediadoras de metal}

Os meios de cultivo para isolamento de microrganismos resistentes a metais pesados devem conter nutrientes essenciais, tais como as fontes de carbono/energia, hidrogênio, oxigênio, nitrogênio, fósforo, enxofre, e além de cofatores, precursores e elementos traço em concentrações que resultem no crescimento do microrganismo (PEREIRA; BOM; FERRARA, 2008). Tais exigências nutricionais podem ser satisfeitas pelo uso de meios complexos ou mínimos. Meios mínimos ou sintéticos são os que apresentam apenas os nutrientes essenciais ao crescimento, os quais são mais indicados para os estudos de sorção de metais pesados em microrganismos, pois os meios complexos apresentam componentes (proteínas, aminoácidos, dentre outros) que podem influenciar o processo de interação de metais com os microrganismos (ANDREAZZA, 2009).

\subsubsection{Glicerol}

O glicerol ou propano-1,2,3-triol é um composto orgânico pertencente à função álcool. É líquido à temperatura ambiente $\left(25^{\circ} \mathrm{C}\right)$, higroscópico, inodoro, viscoso e de sabor adocicado (IUPAC, 1993).

Estima-se que para cada $1000 \mathrm{~L}$ de biodiesel produzidos pelo processo de transesterificação de óleos vegetais, são gerados $100 \mathrm{~kg}$ de glicerol bruto. No Brasil, a quantidade de glicerol vem crescendo com o aumento na produção do biodiesel, pois a partir do ano de 2008, a mistura de biodiesel puro (B100) ao óleo diesel passou a ser obrigatória pela Agência Nacional de Petróleo (ANP). Entre janeiro e junho de 2008, a mistura de biodiesel (B100) foi de $2 \%$, entre julho de 2008 e junho de 2009 foi de $3 \%$ e entre julho e dezembro de 2009 foi de $4 \%$. A partir de janeiro de 2010, o percentual da mistura exigido passou a ser de $5 \%$ conforme a resolução CNPE n. 6 de 2009. A Figura 1 mostra a produção crescente de biodiesel a partir do ano de 2007 até 2013. 


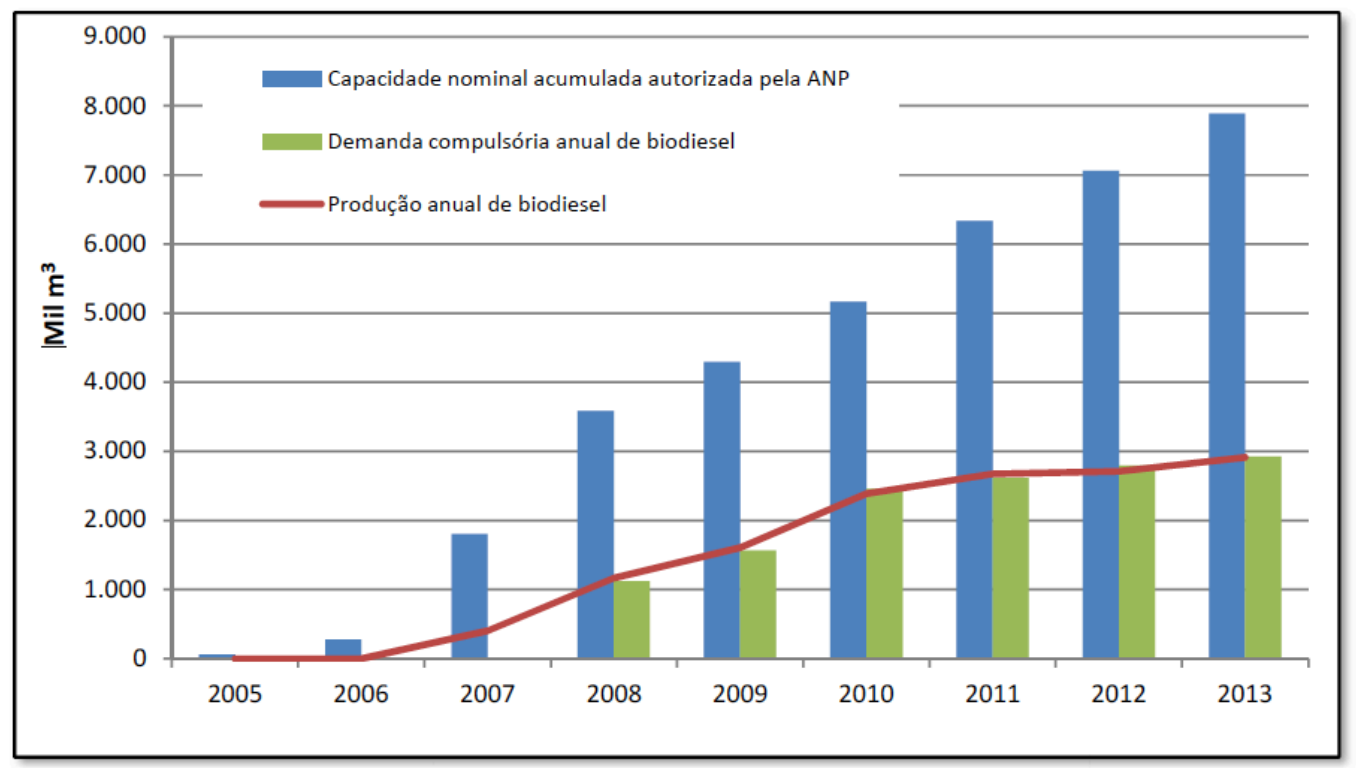

Figura 1 - Evolução da Produção de Biodiesel (Fonte: Boletim da ANP, Julho de 2014)

A produção de biodiesel foi de $3.000 .000 \mathrm{~m}^{3}$ no ano de 2013 , e isto gerou, no mínimo, 30.000 toneladas de glicerol bruto produzidas. Devido a pressões ambientais e legislação citada acima, a demanda pela utilização de biodiesel é crescente, consequentemente, a quantidade de glicerol gerada será cada vez maior.

Portanto, o glicerol se destaca, dentre as fontes de carbono e energia, e é uma fonte alternativa de carbono altamente assimilável por bactérias e leveduras sob condições aeróbias e anaeróbias (DILLIS et al., 1980).

Na Figura 2 é apresentada a rota metabólica do glicerol nas bactérias e leveduras. O glicerol é oxidado à dihidroxicetona pela enzima glicerol desidrogenase. A dihidroxicetona é fosforilada a dihidroxicetona-fosfato pela enzima dihidroxicetona quinase. Após a formação de dihidroxicetona fosfato, várias vias são possíveis para metabolizar este composto, dependendo das necessidades nutricionais e fisiológicas da célula. Os intermediários gerados no Ciclo de Krebs permitem a posterior formação de aminoácidos, essenciais para a formação de proteínas por mecanismo de tradução. Para a metabolização do glicerol e para o Ciclo de Krebs permanecer ativo, há necessidade de $\mathrm{O}_{2}$ para a reoxidação eficiente das coenzimas NADH. 


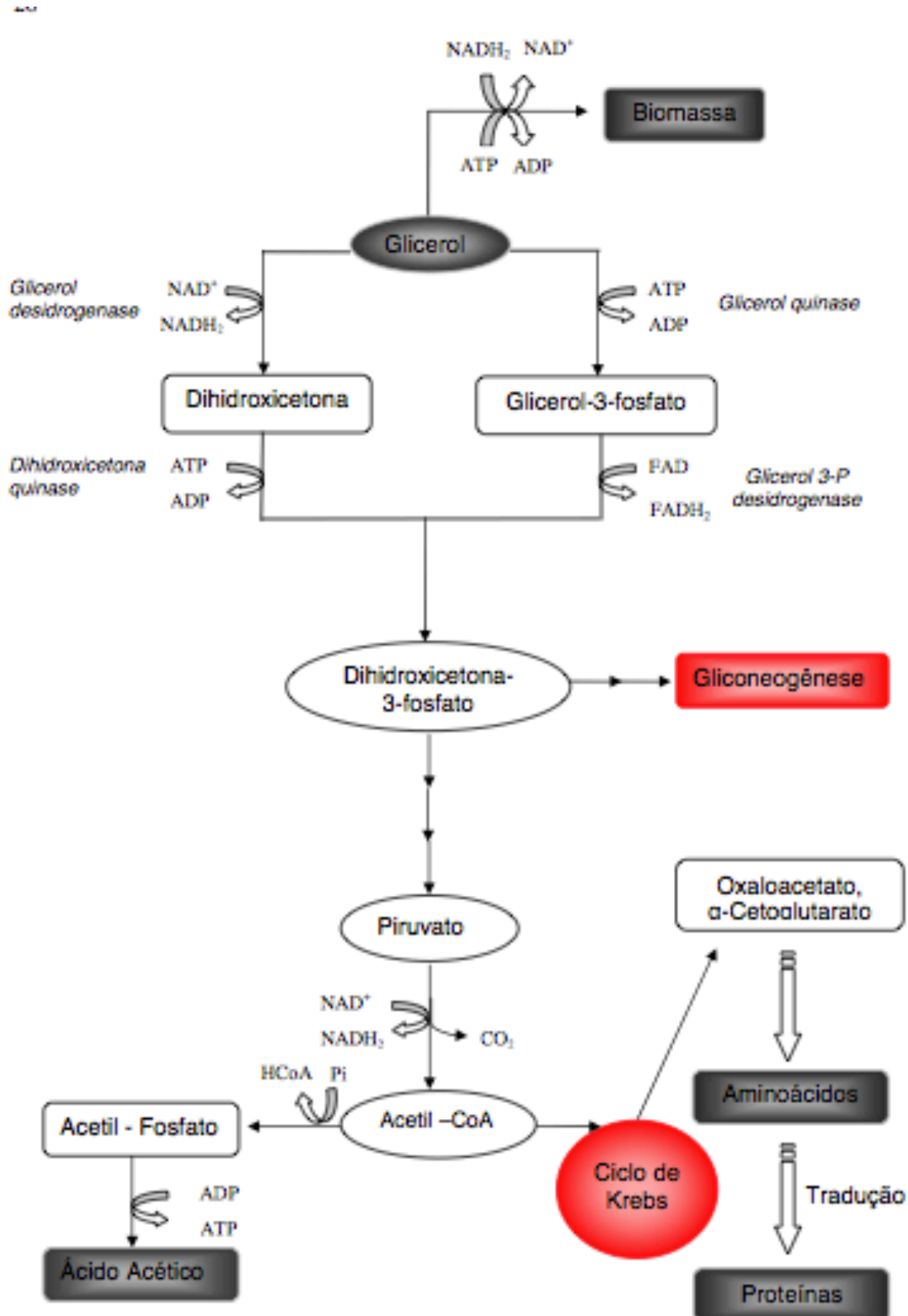

Figura 2 - Via metabólica de assimilação de glicerol por leveduras e bactérias (Adaptado de: PAPANIKOLAOU et al., 2008, BARBOSA, 2012)

\subsection{Sorção de Cobre em Bactérias}

Diversas bactérias são relatadas na literatura com capacidade de sorção de metais pesados, dentre elas, pode-se destacar as bactérias do gênero Pseudomonas e Cupriavidus, que estão frequentemente presentes em regiões 
contaminadas com cobre. Na Tabela 4 verifica-se a capacidade de sorção de cobre de diferentes bactérias.

Tabela 4 - Sorção de Cobre por bactérias

\begin{tabular}{|c|c|c|}
\hline Bactéria & $\begin{array}{c}\mathrm{Cu}^{+2} \text { Sorvido } \\
\text { (mg/g de } \\
\text { biomassa } \\
\text { seca) }\end{array}$ & Referência \\
\hline Bacillus subtilis & 11,00 & Mayers; Beveridge (1989) \\
\hline Brevibacterium $s p$ & 34,34 & Vecchio (1998) \\
\hline Bacillus sp. (esporos) & 52,40 & He; Tebo (1998) \\
\hline Pseudomonas aeruginosa & 14,12 & Langley; Beveridge (1999) \\
\hline $\begin{array}{l}\text { Enterobacter aerogenes } \\
\text { NTG-01 }\end{array}$ & 25,12 & Huang; Chen; Xu (2005) \\
\hline Pseudomonas putida CZ1 & 27,20 & Chen et al. (2005) \\
\hline $\begin{array}{l}\text { Cupriavidus taiwanensis } \\
\text { TJ208 }\end{array}$ & 19,00 & Chen et al. (2008) \\
\hline $\begin{array}{l}\text { Pseudomonas putida } \\
\text { (NRRL B-255) }\end{array}$ & 49,50 & Uslu; Tanylol (2006) \\
\hline Bacillus sp. & 16,25 & Tunali; Çabuk; Akar (2006) \\
\hline $\begin{array}{l}\text { Cupriavidus metallidurans } \\
\mathrm{CH} 34\end{array}$ & 38,72 & $\begin{array}{l}\text { Fan; Okayak; Rodrigues, } \\
\text { (2014) }\end{array}$ \\
\hline
\end{tabular}

A Pseudomonas é um gênero de bactérias gram-negativas em formato de bacilo e é amplamente encontrada na água e solo do meio ambiente. Dentre as versatilidades das bactérias do gênero Pseudomonas existem diversos relatos sobre a capacidade de sorção de metais pesados como cobre, níquel, chumbo e zinco (CÁNOVAS; CASES; LORENZO, 2003; CHEN et al. 2005; HUANG; CHEN; XU, 2005; JUNLIAN et al. 2010; KUMAR et al., 2011; PATHAK; DASTIDAR; SRREKRISHNAN, 2009). A capacidade de adsorção de metais pesados na parede celular das bactérias do gênero Pseudomonas é propiciada através de polissarideos extracelulares secretados (EPS), lipopolissacarideos e proteínas, sendo que estes componentes apresentam grupos funcionais capazes de ligar metais, além da capacidade de bioacumulação, conforme mecanismo descrito no item 2.3.2.

\subsection{Cultivo de Alta Densidade Celular para bactérias do gênero Pseudomonas}

Riesenberg e Guthke (1999), publicaram mini-revisão sobre cultivos de alta 
densidade celular e relataram as dificuldades da realização desta forma de cultivo, que são principalmente manter a solubilidade de substratos sólidos e aquosos em meios aquosos, limitaçào e/ou inibição do crescimento em relação aos substratos, instabilidade e volatilidade de substratos e produtos, acúmulo de produtos ou subprodutos metabólicos a um nível inibidor do crescimento, produtos de degradação, altas taxas de evolução de $\mathrm{CO}_{2}$ e calor, alta demanda por oxigênio e aumento na viscosidade do meio em cultivos muito densos.

Diversos autores relatam 0 cultivo de alta densidade celular para Pseudomonas putida principalmente para a produção de PHA (polihidroxialcanoato) e PHB (polihidroxibutirato).

Sun et al. (2006) relataram cultivos de alta densidade utilizando diferentes formas de alimentação de glicose e nutrientes: na forma de alimentação exponencial com valor de $\mu$ pré-determinado, alimentação exponencial com base no $\mu_{\max }$ estimado, alimentação semi-contínua baseada na detecção de limitação de substrato e alimentação contínua com base no consumo cumulativo de glicose estimado. Foram obtidos entre 65 - 80 gramas de massa seca células. O maior valor de produtividade foi obtido para a alimentação contínua com base na estimativa do consumo cumulativo de glicose.

Sun et al. (2009) realizou cultivos de co-alimentação com ácido nonânico (NA) e glicose para melhorar o rendimento de PHA a partir de NA. A alimentação foi feita seguinda de alimentação linear utilizando um valor de $\mu$ pré-determinado sendo obtido $71 \mathrm{~g} / \mathrm{L}$ de massa de seca de células.

Diniz et al. (2004) realizou cultivo de alta densidade celular para Pseudomonas putida IPT046 para a produção PHA utilizando a alimentação exponencial da glicose e frutose, que foi antecipada de um pulso de alimentação. As máximas concentrações celulares variaram entre 35 e $50 \mathrm{~g} / \mathrm{L}$.

Lee et al. (2000) realizou cultivos de batelada alimentada por pulso para a bactéria Pseudomonas putida KT2442 utilizando como fonte de carbono e energia ácido óleico para produção de PHA e foi obtido a concentração celular de $173 \mathrm{~g} / \mathrm{L}$ em reator de volume útil de $6 \mathrm{~L}$.

No trabalho de Kim et al. (1996) foram descritos cultivos de alta densidade celular para Pseudomonas putida BM01 utilizando alimentação de glicose utilizando o controle do pH e foi obtido a concentração celular de $100 \mathrm{~g} / \mathrm{L}$.

Castro (2012) realizou cultivos de batelada alimentada com alimentação 
exponecial com valor de $\mu$ pré-determinado para Pseudomonas putida KT2440 e foi obtido a concentração celular de $51 \mathrm{~g} / \mathrm{L}$.

Como observado nos dados da literatura, é possível a realização de cultivos de alta densidade para bactérias do gênero Pseudomonas utilizando-se diferentes fontes de carbono e energia. Entretanto, deve-se escolher uma forma de alimentação do cultivo mais adequada para a finalidade pretendida. Neste trabalho, foi realizada a alimentação por pulsos manuais e alimentação exponencial 


\section{OBJETIVOS}

\subsection{Objetivo Principal}

O presente trabalho tem por objetivo isolar um microrganismo da Mina de Sossego da Vale (Carajás, PA) e avaliar sua capacidade de sorção de cobre através de cultivos em reator.

\subsection{Objetivos Específicos}

- Isolar e identificar bactérias resistentes aos metais cobre e níquel, a partir de amostras de solo e água coletadas na Mina de Sossego;

- Selecionar meio de cultivo sintético, dentre meios disponíveis na literatura, adequado ao crescimento celular com glicose ou glicerol como fontes de carbono, para duas bactérias resistentes a cobre e níquel; avaliar o desempenho do crescimento com base no valor de $\mu_{\max }$, fator de conversão de glicose ou glicerol a células, $Y_{X / S}$ e capacidade de consumir glicerol;

- Determinar a capacidade de sorção de $\mathrm{Cu}^{2+}$ e as Isotermas de Langmuir para as duas bactérias selecionadas;

- Definir um processo de sorção de cobre para a bactéria selecionada em escala de bancada utilizando reator. 


\section{MATERIAIS E MÉTODOS}

\subsection{Mina de Sossego da Vale em Carajás - PA}

A Mina de Sossego tem capacidade de produção estimada em 150 milhões de toneladas de cobre por ano, a partir de minério com $1,00 \%$ de teor médio de cobre e $0,29 \mathrm{~g}$ de ouro/t.

A Figura 3 mostra algumas imagens da Mina de Sossego, onde o processo de extração de minério é realizado com a utilização de equipamentos de grande porte gerando uma cava de alta profundidade (200-300 m) (Figura 3B). Depois da lavra, o minério de cobre é alimentado em um britador que reduz o tamanho do material extraído, segue transportado por esteira até um moinho e, posteriormente, o material particulado é enviado para o processo de flotação obtendo minério de cobre concentrado e rejeitos. $\mathrm{O}$ concentrado é desaguado no espessador o qual retira a maior parte da água. Concentrado e água são então bombeados para a filtração. Ao final deste processo de beneficiamento, a rocha, cujo teor inicial médio era de $1 \%$ de cobre, alcança concentração de $30 \%$. O concentrado de cobre é transportado em caminhões até um armazém, no munícipio de Parauapebas, de onde segue de trem pela Estrada de Ferro Carajás até o Terminal Marítimo de São Luís, onde é embarcado para o mercado brasileiro e mundial. $O$ rejeito e a água resultantes do processo são lançados em uma lagoa (Figura 3C). 

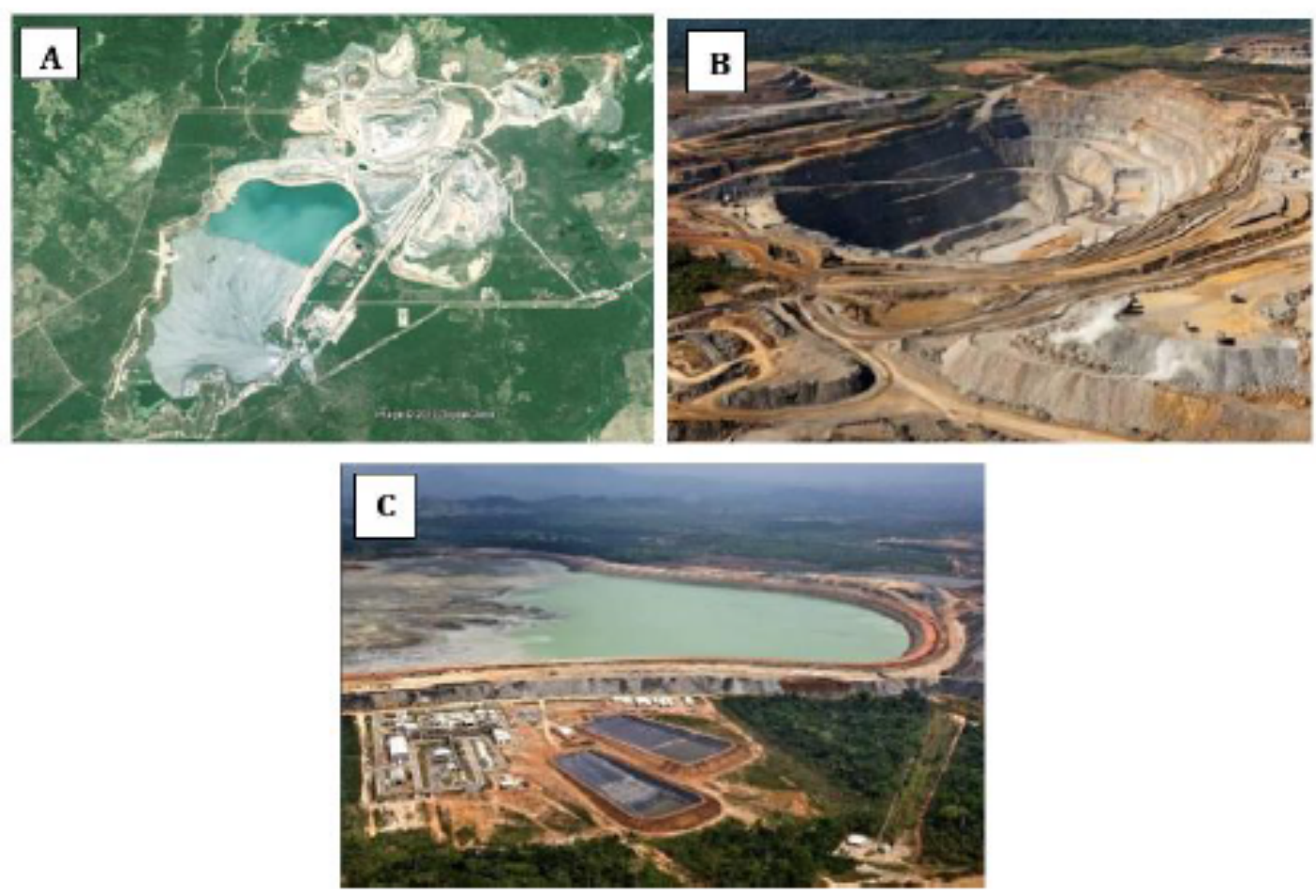

Figura 3 - Imagens da Mina de Sossego da VALE. A: imagem aérea (Google Earth); B: Foto da cava da Mina e C: Foto da lagoa de rejeitos do processamento do minério.

\subsection{Isolamento de bactérias da Mina de Sossego}

Quantidades de $1 \mathrm{~g}$ de solo ou $1 \mathrm{~mL}$ de efluente líquido coletadas em diferentes regiões da Mina de Sossego foram incubadas em tubos de ensaio com 5 $\mathrm{mL}$ de cada um dos três diferentes meios de cultivo, a saber, meio MJS, meio TSM e meio Ramsay (descritos no item 4.5) sob agitação de 180 RPM a $30{ }^{\circ} \mathrm{C}$ por 48 horas para o crescimento das bactérias presentes nas amostras.

Para as amostras de solo e água que apresentaram crescimento celular, procedeu-se um novo cultivo em $5 \mathrm{~mL}$ do mesmo meio onde houve crescimento, adicionado dos metais cobre ou níquel nas formas de cloretos. As concentrações de $\mathrm{Cu}^{2+}$ foram as seguintes: 1,$25 ; 2,50 ; 5,00 ; 6,0 ; 6.5 ; 7,0 ; 8,0 ; 8,50 ; 9,0$ e 10,00 mM e para $\circ \mathrm{Ni}^{2+}$ foram as seguintes: 1,25; 2,50; 5,00 e 10,00 mM. Esses cultivos foram conduzidos em incubador rotativo sob agitação de 180 RPM a $30^{\circ} \mathrm{C}$ por 48 horas.

Foi empregada a técnica de semeadura por esgotamento no mesmo meio onde houve crescimento acrescido de ágar, $2 \%$. A técnica de semeadura por esgotamento consiste em depositar uma alíquota da suspensão celular sobre um ponto da superfície de um meio de cultivo solidificado com ágar, e espalhá-la em 
dois ou três setores com o auxílio de alça bacteriológica, sem aporte adicional da suspensão celular, de modo a inocular o meio com quantidades progressivamente menores de células, e assim, possivelmente, obter colônias perfeitamente isoladas.

\subsection{Preservação das Bactérias Isoladas}

Dentre as colônias obtidas na semeadura por esgotamento descrita em 4.2, foram escolhidas as duas mais resistentes a cobre e níquel separadamente. Para preservação das bactérias isoladas, foi realizado cultivo utilizando as mesmas condições do isolamento, posteriormente, alíquotas destes cultivos foram centrifugadas a 10.000 g em tubos Eppendorf (Eppendorf, Hamburg, Alemanha) de $1,5 \mathrm{~mL}$, o sobrenadante foi descartado e foi adicionado glicerol a $30 \%(\mathrm{v} / \mathrm{v})$ para armazenamento em ultrafreezer $\mathrm{a}-80^{\circ} \mathrm{C}$.

\subsection{Identificação dos isolados bacterianos por meio do sequenciamento do gene 16S rRNA}

\subsubsection{Extração de DNA genômico}

Extraiu-se o DNA genômico total das bactérias, foi utilizado o método descrito por Ausubel et al. (1987) baseado na extração por fenol-clorofórmio.

\subsubsection{Análise eletroforética de DNA em gel de agarose e purificação de fragmentos}

A análise e a separação de fragmentos do DNA foi realizada em geis de agarose $0,8 \%$ contendo $0,5 \mu \mathrm{g} / \mathrm{mL}$ de brometo de etídio, submetidos a $80 \mathrm{~V}$ por 2 horas em tampão de corrida 0,5x TBE (Tris $89 \mathrm{mM}$, ácido bórico $89 \mathrm{mM}$, EDTA $20 \mathrm{mM} \mathrm{pH} \mathrm{8,0).} \mathrm{A} \mathrm{quantificação} \mathrm{do} \mathrm{DNA} \mathrm{presente} \mathrm{nas} \mathrm{amostras} \mathrm{foi} \mathrm{realizada}$ comparando a intensidade da fluorescência da amostra com aquela exibida por $\lambda$ DNA de concentração conhecida e marcador molecular DNA Ladder 100 pb e 1000pb (Fermentas, Vilnius, Lituânia).

\subsubsection{Reações de PCR (Reação de Polimerização em Cadeia) e clonagem}

A amplificação do gene $16 S$ rDNA foi realizada utilizando 10 pmol de cada um dos primers na Tabela 4, $200 \mu \mathrm{M}$ de dNTP, 1x de tampão para PCR (Biotools, Madri, 
Espanha), e 2,5 U de taq polimerase (Biotools), 1,5 mM de $\mathrm{MgCl}_{2}$ e 30-50 ng de DNA genômico, totalizando um volume final de $25 \mu \mathrm{L}$. A reação contida em um microtubo foi transferida para um Termociclador Bio-Rad (Bio-Rad, Berkeley, EUA) para realizar a amplificação com 35 ciclos de $95{ }^{\circ} \mathrm{C}$ por 1 minuto de desnaturação, $50{ }^{\circ} \mathrm{C}$ por 1 minuto de anelamento e $72{ }^{\circ} \mathrm{C}$ por 3 minutos de extensão. Ao término dos 35 ciclos houve uma extensão final de $72{ }^{\circ} \mathrm{C}$ por 10 minutos. Os produtos da amplificação foram purificados com kit PCR Clean-Up System (Promega, Madison, EUA) e quantificados através de comparação com marcador de DNA 100 pb e $\lambda$ DNA (100 ng). Os fragmentos foram clonados no vetor pJET 1.2 Blunt (Fermentas) conforme as especificações do catálogo do produto. Para isto, $75 \mathrm{ng}$ do produto de PCR foi tratado com a enzima DNA Blutting (Fermentas) durante 5 minutos a $70{ }^{\circ} \mathrm{C}$ e, posteriormente acrescido de 50 ng do vetor pJET 1.2 Blunt e a enzima T4 ligase (Fermentas). Após a incubação por 5 minutos em temperatura ambiente, $2 \mu \mathrm{L}$ da amostra foram utilizados para transformar células eletrocompetentes de $E$. coli DH5a. Os transformantes foram selecionados em meio LB suplementado com 100 $\mu \mathrm{g} / \mathrm{mL}$ de ampicilina, seis colônias de cada transformação tiveram o DNA plasmidial isolado.

Tabela 5 - Iniciadores utilizados nas reações de PCR (Reação de Polimerização em Cadeia) e clonagem

\begin{tabular}{cccc}
\hline \multicolumn{2}{c}{ Nome } & Sequência & Finalidade \\
\hline 16s & $16 S_{27 F}$ & 5'-AGAGTTTGATCA/CTGGCTCAG-3' & Amplificação \\
rDNA & $16 S_{1492 R}$ & 5'-TACGGT/CTACCTTGTTACGACTT-3 & do gene 16S \\
& & & rDNA \\
\hline
\end{tabular}

\subsubsection{Mini-preparação}

Uma suspensão celular de cada bactéria transformada na concentração de $100 \mathrm{mg} / \mathrm{mL}$ foi inoculada em $5 \mathrm{~mL}$ de meio de cultivo LB e foi cultivado por 16 horas a $37^{\circ} \mathrm{C}$ e $180 \mathrm{RPM}$. Um volume de $2 \mathrm{~mL}$ desse cultivo foi centrifugado por 2 minutos a 8000 g. O precipitado foi ressuspendido em $300 \mu \mathrm{L}$ de solução 1 (EDTA 0,5 M pH 8.0, Tris- $\mathrm{HCl} 0,5 \mathrm{M} \mathrm{pH} 8.0$,dextrose $0,5 \mathrm{M}$ ) e em seguida $300 \mu \mathrm{L}$ de solução 2 ( $\mathrm{NaOH}$ $1,0 \mathrm{M}$, SDS $1 \%$ ) foram adicionados e a mistura foi mantida por 5 minutos a temperatura ambiente. Adicionaram-se então, $300 \mu \mathrm{L}$ de solução 3 (11,5\% de ácido 
acético glacial, $60 \%$ acetato de potássio $5 \mathrm{M}$ ), prosseguiu-se com leve agitação dentro de cuba contendo gelo por 10 minutos. $O$ material foi centrifugado por 15 minutos a $4{ }^{\circ} \mathrm{C}$ e $10000 \mathrm{~g}$. O sobrenadante foi recuperado e o precipitado descartado. Adicionaram-se $10 \mu \mathrm{L}$ de RNAse $(10 \mathrm{mg} / \mathrm{mL})$ no sobrenadadante e incubou-se por 30 minutos a $37^{\circ} \mathrm{C}$. Em seguida, adicionou-se $750 \mu \mathrm{L}$ de clorofórmio:álcool isoamílico $(24: 1, \mathrm{v} / \mathrm{v})$ e novamente centrifugou-se por 2 minutos a $4{ }^{\circ} \mathrm{C}$ e $10000 \mathrm{~g}$. A fase aquosa foi recuperada e adicionou-se $600 \mu \mathrm{L}$ de isopropanol, incubou-se por 30 minutos em temperatura ambiente, e então, centrifugou-se por 15 minutos a $4{ }^{\circ} \mathrm{C}$ e $10000 \mathrm{~g}$. O precipitado foi lavado com etanol (70\%) e em seguida ressuspendido em água ultra-pura.

\subsubsection{Sequenciamento da região $16 S$ rRNA}

Os fragmentos de DNA da região 16S rRNA foram sequenciados com $A B I$ 3730 DNA Analyser (Applied Biosystems, Foster City, EUA) no Departamento de Genoma Humano do Instituto de Biociências da USP. O resultado do sequenciamento foi analisado com o auxílio do programa computacional Codon Code para verificação da qualidade das bases. A análise de similaridade foi realizada através do programa blastn disponível na internet pelo Centro Nacional de Informação Biotecnológica (ALTSCHUL et al., 1997).

\subsection{Meios de Cultivo}

Os meios de cultivo utilizados neste trabalho foram:

- Meio LB: 10,00 g/L de hidrolisado de caseína; 5,00 g/L de extrato de levedura $5,00 \mathrm{~g}$ e $10 \mathrm{~g} / \mathrm{L}$ de cloreto de sódio.

- Meio Caldo Nutriente: 3,00 g/L de extrato de carne e 5,00 g/L peptona.

- Meio sintético TSM: 6,06 g/L de Tris; 4,68 g/L de NaCl; 1,49 g/L de $\mathrm{KCl} ; 1,07$ $\mathrm{g} / \mathrm{L}$ de $\mathrm{NH}_{4} \mathrm{Cl} ; 0,43 \mathrm{~g} / \mathrm{L}$ de $\mathrm{Na}_{2} \mathrm{SO}_{4} ; 0,2 \mathrm{~g} / \mathrm{L}$ de $\mathrm{MgCl}_{2} .6 \mathrm{H}_{2} \mathrm{O} ; 0,03 \mathrm{~g} / \mathrm{L}$ de $\mathrm{CaCl}_{2} .2 \mathrm{H}_{2} \mathrm{O}$; $0,23 \mathrm{~g} / \mathrm{L}$ de $\mathrm{Na}_{2} \mathrm{HPO}_{4} \cdot 12 \mathrm{H}_{2} 0 ; 0,005 \mathrm{~g} / \mathrm{L}$ de $\mathrm{Fe}(\mathrm{III})\left(\mathrm{NH}_{4}\right) ; 1 \mathrm{~mL}$ de solução de elementos traço SL7 (MERGEAY et al., 1985).

- Meio sintético M9: 6,78 g/L de $\mathrm{Na}_{2} \mathrm{HPO}_{4} ; 3,00 \mathrm{~g} / \mathrm{L}$ de $\mathrm{KH}_{2} \mathrm{PO}_{4} ; 0,50 \mathrm{~g} / \mathrm{L}$

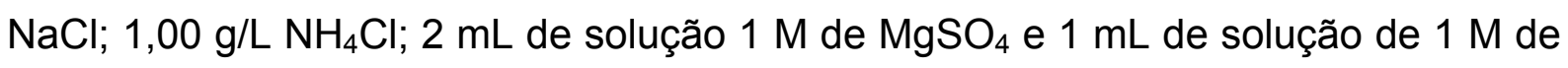
$\mathrm{CaCl}_{2}$ (SCHARFMAN et al., 1996). 
- Meio sintético M63: 13,60 g/L de $\mathrm{KH}_{2} \mathrm{PO}_{4} ; 0,50 \mathrm{mg} / \mathrm{L} \mathrm{FeSO}{ }_{4} .7 \mathrm{H}_{2} \mathrm{O}, 2,00 \mathrm{~g} / \mathrm{L}$ de $\left(\mathrm{NH}_{4}\right)_{2} \mathrm{SO}_{4}$ e $1 \mathrm{~mL}$ de solução $1 \mathrm{M}$ de $\mathrm{MgSO}_{4}$ (WOLFGANG et al., 2004 e NINGTHOUJAM; SHOVARANI, 2008).

- Meio sintético Ramsay 2006-1: 9,54 g/L de $\mathrm{Na}_{2} \mathrm{HPO}_{4} ; 4,77 \mathrm{~g} / \mathrm{L}$ de $\mathrm{KH}_{2} \mathrm{PO}_{4}$; $0,80 \mathrm{~g} / \mathrm{L}$ de $\mathrm{MgSO}_{4} .7 \mathrm{H}_{2} \mathrm{O}$ e $8 \mathrm{~mL} / \mathrm{L}$ de solução traços (SUN et al., 2006).

- Meio sintético Ramsay 2006-2: 4,77 g/L de $\mathrm{Na}_{2} \mathrm{HPO}_{4} ; 2,03 \mathrm{~g} / \mathrm{L}$ de $\mathrm{KH}_{2} \mathrm{PO}_{4}$; $0,80 \mathrm{~g} / \mathrm{L}$ de $\mathrm{MgSO}_{4} .7 \mathrm{H}_{2} \mathrm{O}$ e $10 \mathrm{~mL} / \mathrm{L}$ de solução traços (SUN et al., 2009).

- Meio Mineral MM: 1,50 g/L de $\left(\mathrm{NH}_{4}\right)_{2} \mathrm{SO}_{4} ; 3,50 \mathrm{~g} / \mathrm{L}$ de $\mathrm{Na}_{2} \mathrm{HPO}_{4} ; 1,50 \mathrm{~g} / \mathrm{L}$ de $\mathrm{KH}_{2} \mathrm{PO}_{4} ; 0,20 \mathrm{~g} / \mathrm{L}$ de $\mathrm{MgSO}_{4} .7 \mathrm{H}_{2} \mathrm{O} ; 0,01 \mathrm{~g} / \mathrm{L}$ de $\mathrm{CaCl}_{2} .2 \mathrm{H}_{2} \mathrm{O} ; 0,06 \mathrm{~g} / \mathrm{L}$ de citrato de ferro amoniacal; $0,50 \mathrm{~g} / \mathrm{L}$ de extrato de levedura e $1 \mathrm{~mL} / \mathrm{L}$ de solução traços (TACIRO, 2008)

O Meio Mineral MM foi adaptado para os cultivos de alta densidade celular em reator, passando a ser identificado por meio MM-HCD.

- Meio Mineral MM-HCD 1,50 g/L de $\left(\mathrm{NH}_{4}\right)_{2} \mathrm{SO}_{4} ; 3,50 \mathrm{~g} / \mathrm{L}$ de $\mathrm{Na}_{2} \mathrm{HPO}_{4} ; 1,50$ $\mathrm{g} / \mathrm{L}$ de $\mathrm{KH}_{2} \mathrm{PO}_{4} ; 0,20 \mathrm{~g} / \mathrm{L}$ de $\mathrm{MgSO}_{4} .7 \mathrm{H}_{2} \mathrm{O} ; 0,01 \mathrm{~g} / \mathrm{L}$ de $\mathrm{CaCl}_{2} .2 \mathrm{H}_{2} \mathrm{O} ; 0,06 \mathrm{~g} / \mathrm{L}$ de citrato de ferro amoniacal; $0,50 \mathrm{~g} / \mathrm{L}$ de extrato de levedura e $1 \mathrm{~mL} / \mathrm{L}$ de solução traços (adaptado de TACIRO, 2008)

Como fonte de carbono e energia, adicionou-se glicose $(0,50 \% \mathrm{p} / \mathrm{v})$ ou glicerol $99 \%(0,50 \% \mathrm{v} / \mathrm{v}$ ou $0,50 \% \mathrm{p} / \mathrm{v})$. Para os experimentos em reator foi utilizado apenas glicerol, no meio MM foi utilizado $0,50 \%(\mathrm{p} / \mathrm{v})$ e no meio MM-HCD 3,00\% (p/v).

Foram feitas algumas adaptações nos meios de forma a favorecer 0 crescimento, as quais estão descritas a seguir.

No meio de cultivo sintético M9, o cloreto de amônio foi substituído pela ureia, dada a sua melhor assimilação por alguns microrganismos.

No meio de cultivo sintético TSM, diferentes concentrações do tampão TRIS foram aplicadas, a saber, $0,10,0,15,0,20$ e $0,25 \mathrm{mM}$, além da utilização alternativa de ureia, como fonte de nitrogênio em concentração equivalente de nitrogênio ao $\mathrm{NH}_{4} \mathrm{Cl}$, qual seja, de $0,60 \mathrm{~g} / \mathrm{L}$.

O valor do $\mathrm{pH}$ inicial aplicado ao meio sintético TSM foi de 5, 6 e 7, no cultivo da bactéria isolada Cupriavidus metallidurans.

Nos meios Ramsay-2006-1 e 2006-2 a concentração de sulfato de amônio foi variada $(4,70 ; 2,35$ e $0,50 \mathrm{~g} / \mathrm{L})$ de forma a adequá-la ao crescimento. 


\subsection{Cultivos em Incubador Rotativo}

Cultivos em incubador rotativo foram realizados nas seguintes etapas deste trabalho: avaliação dos meios e preparo de inóculo para o reator.

Empregaram-se frascos Erlenmeyer de $250 \mathrm{~mL}$ contendo $50 \mathrm{~mL}$ de meio, nas condições de $30^{\circ} \mathrm{C}$ e 180 RPM.

A concentração inicial de células após a inoculação com a suspensão do estoque foi a mesma para todos os experimentos $(0,003 \mathrm{~g} / \mathrm{L})$.

Os cultivos foram realizados até que o valor da densidade ótica (DO) em 600 $\mathrm{nm}$ indicasse que a fase estacionária do crescimento microbiano havia sido atingida, o que correspondeu a intervalos de 24 até 48 horas.

\subsection{Cultivos em Reator}

Utilizou-se o reator modelo Labfors 5 (Infors, Basel, Suíça) de volume total de 3,6L (Figura 4). Empregaram-se as seguintes condições nos cultivos em regime de batelada simples ou batelada alimentada: 1,60 L de volume inicial, $\mathrm{pH} 7$ controlado pela adição de $\mathrm{NaOH}$ (3 M) ou $\mathrm{HCl}(1 \mathrm{M})$, agitação de $600 \mathrm{RPM}$, temperatura de 30 ${ }^{\circ} \mathrm{C}$, aeração na vazão de 1 vvm e concentração de oxigênio dissolvido mantido em $30 \%$ da concentração de saturação em relação ao ar, por meio da variação da composição da mistura dos gases ar e oxigênio. 


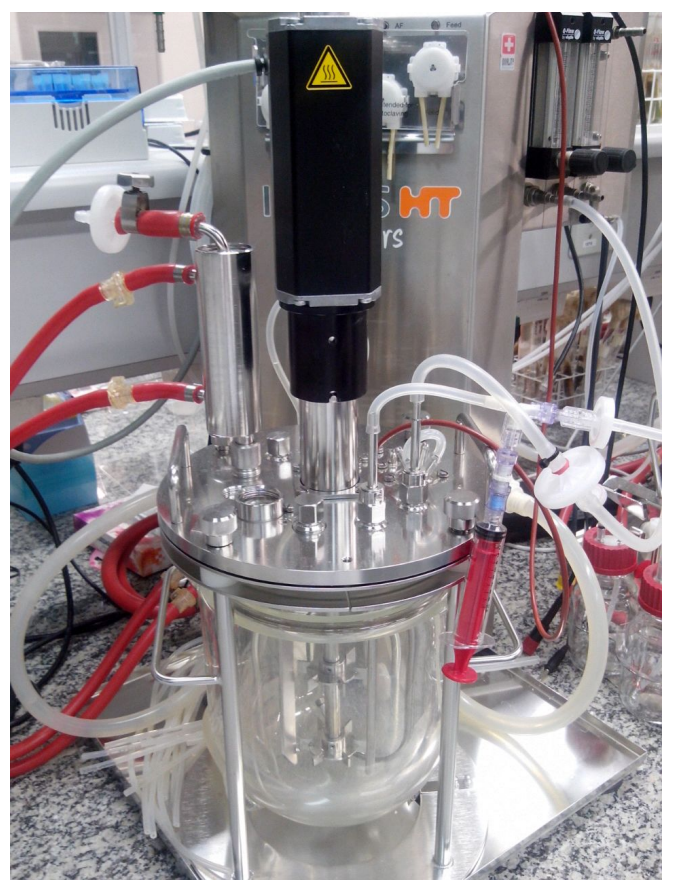

Figura 4 - Reator modelo Labfors 5 utilizado nos cultivos

$\mathrm{Na}$ configuração padrão do reator da Infors existem chicanas internas, duas turbinas modelo Rushton e aspersor em formato de "L" (Figura 5). Além do controlador de $\mathrm{pH}$ e $\mathrm{pO}_{2}$, o qual permite a mistura de gases de ar, oxigênio e nitrogênio. 


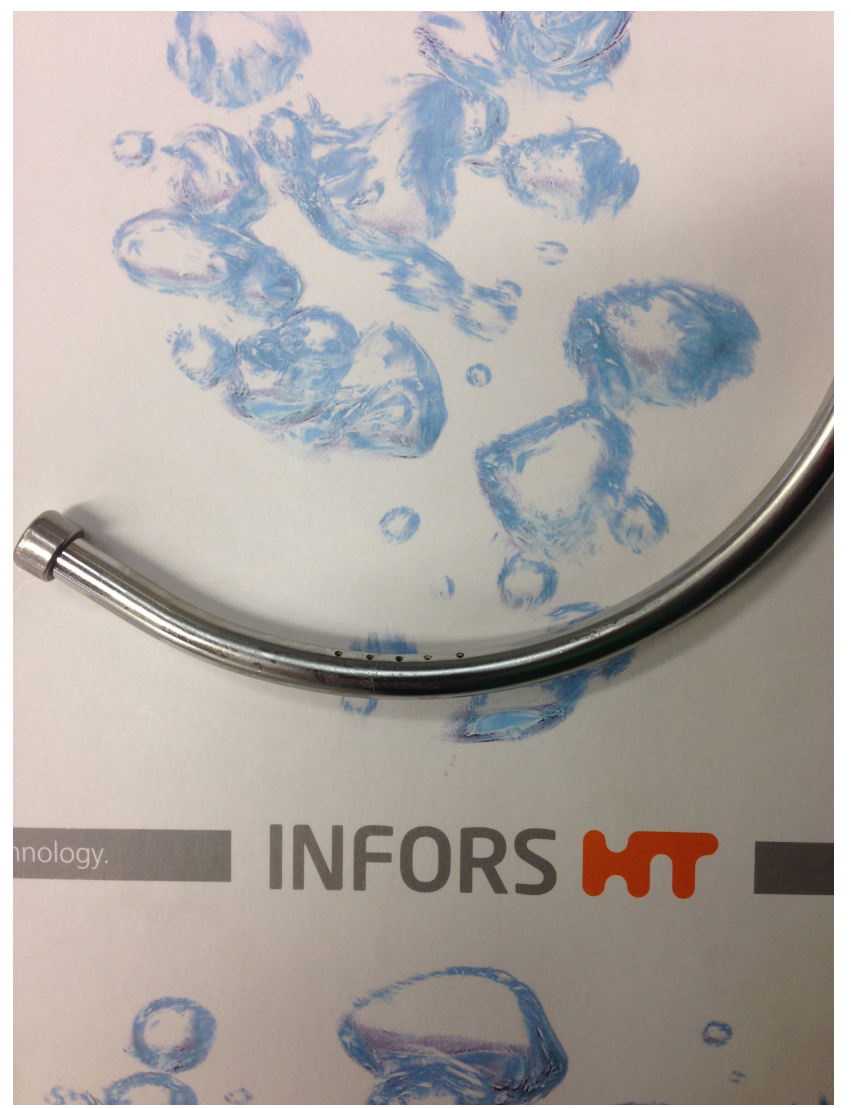

Figura 5 - Aspersor em Formato de "L"

\subsection{Preparo de Inóculo para os Cultivos em Reator}

Para cada cultivo em reator, o inóculo foi realizado da mesma forma, um tubo do tipo Eppendorf contendo o estoque da bactéria foi inoculado em frasco Erlenmeyer de $250 \mathrm{~mL}$ com $50 \mathrm{~mL}$ de meio caldo nutriente sob agitação de 180 RPM a $30{ }^{\circ} \mathrm{C}$ em estufa rotativa. Após 18 horas de cultivo, o caldo cultivado foi inoculado na proporção de $10 \%(\mathrm{v} / \mathrm{v})$ em frascos Erlenmeyer de $500 \mathrm{~mL}$ contendo $100 \mathrm{~mL}$ do meio $\mathrm{MM}$ com $0,50 \%(\mathrm{p} / \mathrm{v})$ de glicerol incubados sob agitação de 180 RPM a $30{ }^{\circ} \mathrm{C}$ em estufa rotativa por 18 até 20 horas. Posteriormente, o caldo cultivado foi centrifugado a $10000 \mathrm{~g}$ por 25 minutos em tubos do tipo Falcon de 50 $\mathrm{mL}$ e o sobrenadante foi descartado. As células foram ressuspendidas em solução salina e inoculadas no reator.

\subsection{Sistema Externo de Filtração Tangencial acoplado ao Reator}

Foi utilizado o sistema de filtração de fibra oca da marca GE (GE, Fairfield, EUA), modelo CFP-4-E-3MA com porosidade de 0,45 $\mu \mathrm{m}$ e área de filtração de 110 
$\mathrm{cm}^{2}$. Através do sistema de filtração ilustrado na Figura 6, realizaram-se cultivos microbianos seguidos de etapa para concentração das células, por meio de recirculação da suspensão celular obtida ao final do cultivo.

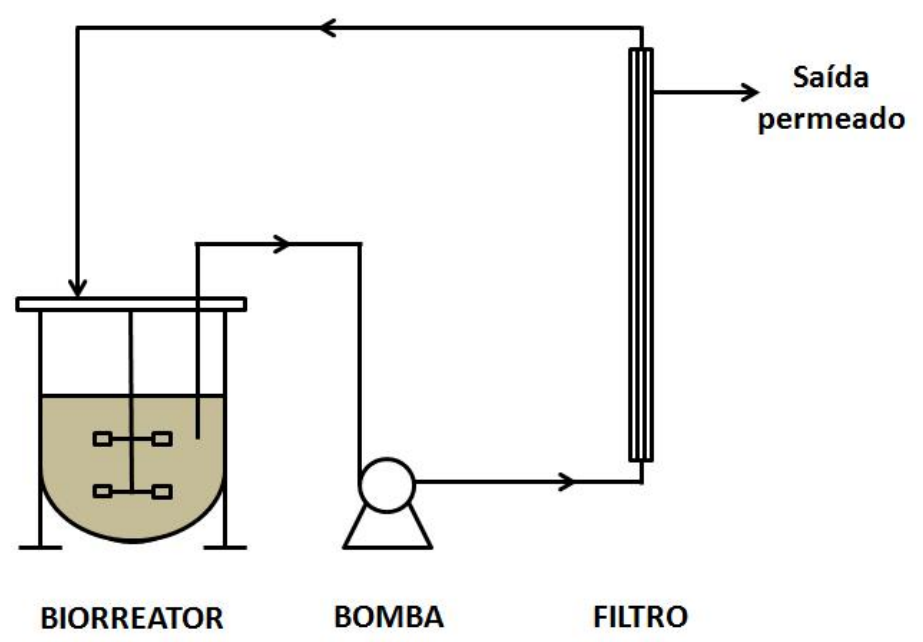

Figura 6 - Sistema externo de filtração de fibra oca acoplado ao reator

\subsection{Função de Vazão de Alimentação Exponencial do Reator}

Foi utilizada a função abaixo para alimentar o reator com glicerol e nutrientes de forma exponencial. Foram utilizadas soluções concentradas com o mesmo volume de glicerol $70 \%(\mathrm{p} / \mathrm{v})$ e demais nutrientes para minimizar o aumento de volume do reator.

$$
F(t)=\left(\frac{\mu}{Y_{X / S}}+m_{S}\right) \cdot \frac{V_{o} \cdot X_{o} \cdot e^{\mu\left(t-t_{o}\right)}}{S_{o}}
$$

onde:

$F(t)$ = Vazão de alimentação em função do tempo (L/h)

$\mathrm{m}_{\mathrm{s}}=$ Coeficiente de manutenção celular (g/g.h)

$\mathrm{V}_{0}=$ Volume inicial $(\mathrm{L})$

$\mathrm{X}_{0}=$ Concentração celular inicial $(\mathrm{g} / \mathrm{L})$

$\mathrm{t}_{0}=$ Tempo inicial da alimentação $(\mathrm{h})$

$\mathrm{S}_{0}=$ Concentração do substrato de alimentação $(\mathrm{g} / \mathrm{L})$ 
A função foi implementada em um microcontrolador modelo Arduino Uno (Arduino, Ivrea, Itália), que controlava uma bomba peristáltica, modelo Minipuls 3 da marca Gilson (Gilson, Villiers Le Bel, França).

\subsection{Sorção de Cobre pelas bactérias isoladas: Isoterma de Langmuir}

O protocolo utilizado para os ensaios de adsorção de cobre foi baseado nos autores Huang et al., 2003 e Fosso-Kankeu et al., 2011.

Foram realizados cultivos das bactérias nos meios que permitiram o melhor desempenho de crescimento para Cupriavidus metallidurans $\mathrm{sp}$ e Pseudomonas putida sp. A massa das células foi coletada na metade da fase logarítmica do crescimento e centrifugada por 45 minutos a $10.000 \mathrm{~g}$ e lavada com solução salina e novamente centrifugada nas mesmas condições. A massa sedimentada de células foi ressuspendida em água ultra-pura $(\mathrm{pH} 5,0)$ contendo as seguintes concentrações de cobre na forma de cloreto: 0,$1 ; 0,50 ; 1,0$ e 2,00 mM.

Um volume de $10 \mathrm{~mL}$ das amostras contendo células na concentração de 0,90 g/L para Cupriavidus metallidurans e de $0,75 \mathrm{~g} / \mathrm{L}$ para Pseudomonas putida, e de solução de cobre, foi transferida para tubos do tipo Falcon de $15 \mathrm{~mL}$, a seguir incubados sob agitação constante a 180 RPM, $30^{\circ} \mathrm{C}$. Foram retiradas amostras de cada concentração de cobre para cada uma das bactérias nos intervalos de 2, 4, $8 \mathrm{e}$ 12 horas. As amostras foram centrifugadas por 20 minutos a $10000 \mathrm{~g}$ e o sobrenadante foi congelado para posterior determinação da concentração de cobre através do ICP-AES (Espectrometria de emissão atômica por plasma acoplado indutivamente) na Central Analítica do Instituto de Química da USP. Todos os experimentos foram realizados em duplicata.

\subsection{Metodologias Analíticas}

A concentração celular, foi determinada em base à massa seca de células Filtrou-se um determinado volume da suspensão microbiana, através da membrana de celulose de porosidade de 0,22 $\mu \mathrm{m}$ (Millipore, Billerica, EUA). O sedimento da filtração foi submetido a secagem em forno microondas com potência de $20 \%$ até massa constante.

A concentração de glicose foi determinada através de método enzimático 
colorimétrico baseado na reação catalisada pela glicose oxidase e peroxidase (GOD-POD) (CARMINATI, 2001).

A concentração de glicerol foi determinada com base em metodologia cromatográfica, em HPLC Shimadzu (Shimadzu, Kyoto, Japão) nas seguintes condições: coluna de exclusão iônica Bio-Rad, modelo Aminex HPX-87H, temperatura da coluna de $60{ }^{\circ} \mathrm{C}$, fluxo do eluente de $\mathrm{H}_{2} \mathrm{SO}_{4}(2 \mathrm{mM}) 0,6 \mathrm{~mL} / \mathrm{min}$ e a deteç̧ão foi realizada por índice de refração a $410 \mathrm{~nm}$.

A determinação de cobre foi realizada no sobrenadante das amostras líquidas centrifugadas $(8000 \mathrm{~g})$, utilizando o Espectrofômetro de Absorção Atômica da Shimadzu modelo AA7000. 


\section{RESULTADOS E DISCUSSÃO}

\subsection{Isolamento de linhagens selvagens resistentes a cobre e níquel}

Os ensaios de isolamento e identificação foram realizados em conjunto com a equipe de pesquisa do ICB, participante do convênio estabelecido entre a VALE, USP e BNDES. As amostras coletadas na Mina de Sossego foram inoculadas nos meios e condições de cultivo conforme descrito em Materiais e Métodos (4.2), visando ao isolamento de linhagens bacterianas autóctones, isto é, linhagens adaptadas ao ambiente contaminado com cobre e níquel, portanto, microrganismos candidatos à biorremediação.

Para amostras líquidas, verificou-se crescimento nos meios MJS e Ramsay, conforme se observa na Figura 7 , enquanto que para amostras de solo houve crescimento somente no meio MJS.

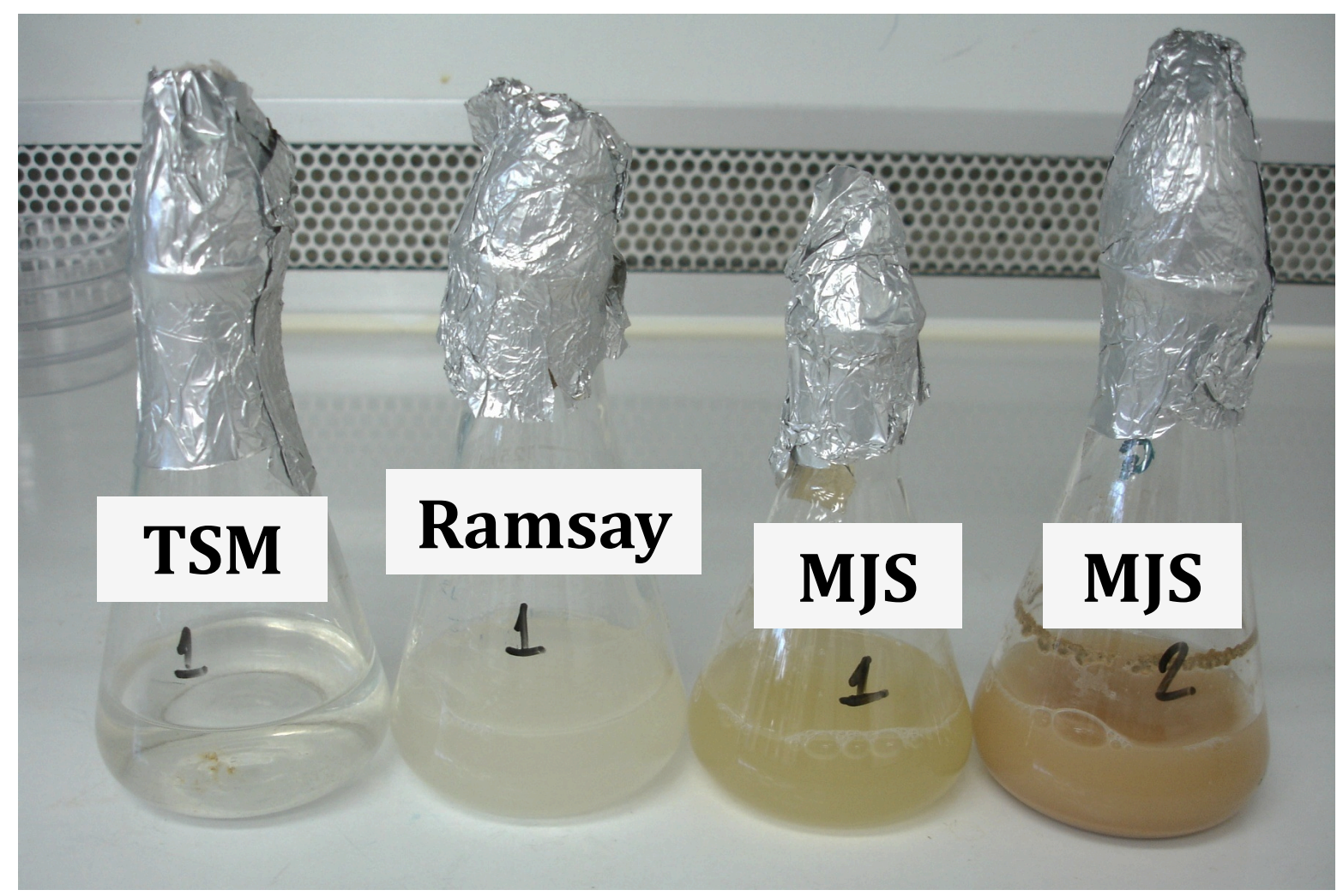

Figura 7 - Crescimento celular nos meios de cultivo TSM, Ramsay e MJS, a partir de amostras líquidas (1) e de solo (2) da região de Mina de Sossego (Carajás, PA).

Frações volumétricas de $1 \mathrm{~mL}$ das amostras que apresentaram crescimento celular foram inoculadas nos mesmos meios de cultivo nos quais apresentaram 
crescimento, acrescidos de $\mathrm{Cu}^{2+}$ ou de $\mathrm{Ni}^{2+}$ nas concentrações de 1,25, 2,50, 5,00, e $10,00 \mathrm{mM}$. A suspensão celular assim obtida foi incubada a $30^{\circ} \mathrm{C}$ por 48 horas sob agitação de 180 RPM. Verificou-se crescimento celular nos meios de cultivo que continham $\mathrm{Cu}^{2+}$ e $\mathrm{Ni}^{2+}$ nas concentrações de 1,25, 2,50 e 5,00 mM.

Posteriormente, amostras das suspensões de células que apresentaram crescimento vigoroso nos meios contendo cobre foram novamente cultivadas na presença deste metal nas concentrações de 6,0;6,5;7,0; 8,0; 8,5; 9,0 e 10,0 mM. À exceção do meio contendo $10,0 \mathrm{mM}$ de cobre, verificou-se crescimento celular para todas as demais condições.

Partindo-se dos cultivos que apresentaram crescimento em meio contendo $\mathrm{Cu}^{2+}$ ou $\mathrm{Ni}^{2+}$, foram isoladas bactérias resistentes a estes metais, por meio da técnica de semeadura por esgotamento, conforme descrito em Materiais e Métodos (4.2). Aplicaram-se aos meios solidificados, as maiores concentrações de cobre e níquel nas quais verificou-se crescimento celular vigoroso em meio líquido, a fim de promover a formação de colônias das bactérias com maior resistência a esses metais (Tabela 6).

Tabela 6 - Condições de cultivo em meio solidificado no isolamento de Bactérias de amostras da área de solo ou líquido da Mina de Sossego (Carajás, PA)

\begin{tabular}{cccc}
\hline Isolado & $\begin{array}{c}\text { Concentração do } \\
\text { metal no isolamento }\end{array}$ & $\begin{array}{c}\text { Meio de Cultivo } \\
\text { Solidificado }\end{array}$ & $\begin{array}{c}\text { Amostra de } \\
\text { origem }\end{array}$ \\
\hline $\mathrm{D}$ & $\mathrm{Ni}^{2+}-2,50 \mathrm{mM}$ & MJS & Efluente líquido \\
$\mathrm{E}$ & $\mathrm{Ni}^{2+}-5,00 \mathrm{mM}$ & MJS & Solo \\
$\mathrm{F}$ & $\mathrm{Cu}^{2+}-7,00 \mathrm{mM}$ & MJS & Efluente líquido \\
$\mathrm{G}$ & $\mathrm{Cu}^{2+}-9,00 \mathrm{mM}$ & $\mathrm{MJS}$ & Solo \\
\hline
\end{tabular}

\subsection{Identificação das linhagens por análise de 16S rRNA}

Após o isolamento de linhagens bacterianas promissoras, ou seja, resistentes a cobre e níquel, as mesmas foram submetidas à identificação por técnicas de biologia molecular na identificação das linhagens bacterianas, que foi 0 sequenciamento de regiões conservadas do $16 \mathrm{~s}$ rRNA, pois, trata-se de metodologia difundida por basear-se em amplo banco de dados para comparação de microrganismos. 
A extração do DNA genômico e amplificação do $16 \mathrm{~S}$ rDNA dos isolados de amostras ambientais (D, E, F e G) foi realizada de acordo com metodologia descrita em Materiais e Métodos (4.4). Observou-se produto de PCR para três amostras apenas $(E, F$ e $G$ ), o qual foi analisado por eletroforese em gel de agarose e apresentou um fragmento de DNA de aproximadamente $1500 \mathrm{pb}$, o qual corresponde ao tamanho do gene $16 \mathrm{~S}$ rDNA (Figura 8). Os fragmentos amplificados de DNA foram clonados no vetor clonJet (Fermentas) e os plasmídeos resultantes foram usados na transformação de células de E. coli DH5a. Para cada amostra (E, F e G), foram obtidos de 10 a 30 transformantes selecionados em meio LB contendo ampicilina. 


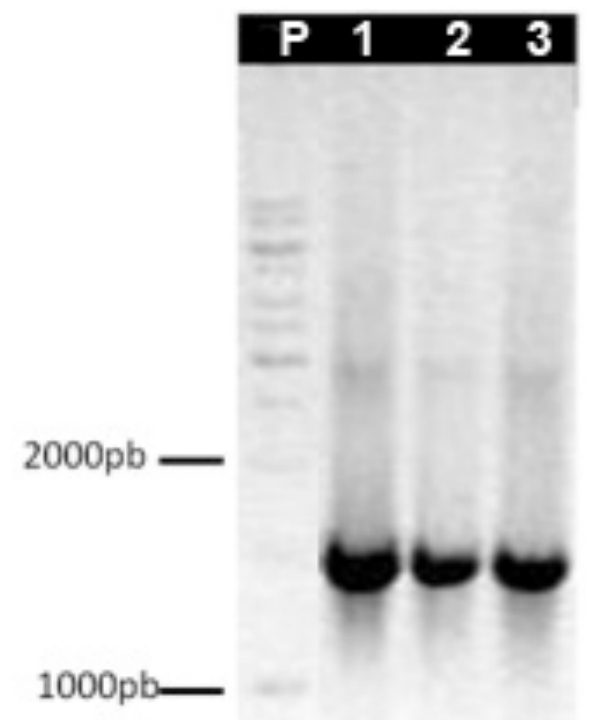

Figura 8 - Perfil de migração dos produtos de PCR da região do 165 rDNA de sete isolados de amostra ambiental (1 a 3 , correspondendo de $\mathrm{E}$ a G, respectivamente) após eletroforese em gel de agarose 0,8\% coradas com brometo de etídeo. P: padrão de peso molecular 100 pb (Fermentas).

O DNA plasmidial de seis transformantes de cada amostra foi isolado e submetido à uma nova PCR do $16 \mathrm{~s}$ rDNA para a confirmação da clonagem. Todas as três amostras apresentaram o produto de amplificação esperado de 1500 bp. Estas regiões gênicas foram sequenciadas utilizando o oligonucleotideo $27 \mathrm{~F}$ ou 1492R (Tabela 5) com ABI 3730 DNA Analyser (Applied Biosystems) no Departamento de Genoma Humano do Instituto de Biociências da USP. O resultado do sequenciamento foi analisado com o auxílio do programa Codon Code para verificação da qualidade das bases (qualidade Phred/Phrad). A análise de similaridade foi realizada através do programa blastn (ALTSCHUL et al., 1997) do Centro Nacional de Informação Biotecnológica disponíveis na internet e os resultados estão apresentados na Tabela 7. Este programa executa um alinhamento local entre uma sequência fornecida (query) contra um banco de dados (subject) que, no caso, são sequências depositadas no banco dados genéticos disponível na internet (Genbank). 
Tabela 7 - Similaridade dos clones obtidos com o banco de dados do Genbank

\begin{tabular}{ccccccc}
\hline Amostras & $\begin{array}{c}\text { Oligonucleotídeo } \\
\text { usado para o } \\
\text { sequenciamento }\end{array}$ & $\begin{array}{c}\text { Sequência } \\
\text { Selecionada } \\
\text { (bp) }\end{array}$ & $\begin{array}{c}\text { Média de } \\
\text { Qualidade } \\
\text { Phred/ } \\
\text { Phrad }\end{array}$ & Similaridade & Linhagem & $\begin{array}{c}\text { Metal e } \\
\text { concentração } \\
\text { do } \\
\text { isolamento }\end{array}$ \\
\hline Isolado E & $27 \mathrm{~F}$ & $\begin{array}{c}19-698(698 \\
\mathrm{bp})\end{array}$ & 39 & $99 \%$ & $\begin{array}{c}\text { Cupriavidus } \\
\text { metallidurans } \\
\text { C-G NA7 }\end{array}$ & $\mathrm{Ni}^{2+}-2,50 \mathrm{mM}$ \\
Isolado F & $27 \mathrm{~F}$ & $15-800(786)$ & 42 & $99 \%$ & $\begin{array}{c}\text { Pseudomonas } \\
\text { putida } \\
\text { BHUJY14 }\end{array}$ & $\mathrm{Ni}^{2+}-5,00 \mathrm{mM}$ \\
Isolado G & $27 \mathrm{~F}$ & $17-686(670)$ & 50 & & & \\
\end{tabular}

Uma boa qualidade de aproximadamente 700 pares de bases foi alcançada para todas as amostras, abrigando as regiões do V1 à V9 do $16 \mathrm{~s}$ rDNA. Com isso, foi possível obter informações significativas sobre a similaridade do $16 \mathrm{~s}$ rDNA parcial dos isolados (Tabela 6). Ambos os isolados, E e G apresentaram uma similaridade de $99 \%$ com a espécie Cupriavidus metallidurans. A amostra $\mathrm{F}$ mostrou $99 \%$ de similaridade com a linhagem BHUJY14 da espécie Pseudomonas putida. As análises para o sequenciamento a partir do oligonucleotideo 1492R também demonstraram similaridade de $99 \%$ com a espécie Cupriavidus metallidurans para os isolados E e G e $99 \%$ de similaridade para a espécie Pseudomonas putida no isolado $\mathrm{F}$.

As duas bactérias selecionadas, Pseudomonas putida BHUJY14 e Cupriavidus metallidurans BMPEZ, foram consideradas candidatas ao prosseguimento dos trabalhos. Entretanto, após a realização de cultivos das referidas bactérias nos meios descritos em Materiais e Métodos, foi detectado erro na identificação dos tubos de estoque das linhagens isoladas do projeto VALE - USP - BNDES, ocasionando a troca de uma das linhagens. A suposta linhagem de Cupriavidus metallidurans BMPEZ era, na realidade, uma Raoultella planticola. Por se tratar de bactéria possivelmente patogênica, os resultados do estudo de crescimento e sorção de cobre da mesma foram suprimidos desta tese. 


\subsection{Avaliação de meios de cultivo para crescimento do isolado bacteriano identificado como Pseudomonas putida sp.}

\subsubsection{Meio sintético TSM com glicose $(0,50 \% \mathrm{p} / \mathrm{v})$ ou glicerol $(0,50 \% \mathrm{v} / \mathrm{v})$}

Avaliou-se o crescimento de Pseudomonas putida sp. em pH 7,0, pois dados de literatura mostram que o $\mathrm{pH}$ ótimo para o crescimento de bactérias do gênero Pseudomonas é em torno de 7,0 (SUN et al., 2006; SUN et al., 2009; TACIRO, 2008).

Os cultivos realizados em meio sintético TSM com glicose $(0,50 \% \mathrm{p} / \mathrm{v})$ e glicerol $(0,50 \% \mathrm{v} / \mathrm{v})$ em pH 7,0 não apresentaram crescimento satisfatório, como se verifica na Tabela 8. As fontes de carbono (glicose ou glicerol) não foram totalmente consumidas, restando concentrações de 3,94 g/L de glicose e 5,44 g/L de glicerol. A concentração celular obtida para o meio com glicose foi de $0,23 \mathrm{~g} / \mathrm{L}$ e para o meio com glicerol foi de $0,65 \mathrm{~g} / \mathrm{L}$.

Tabela 8 - Resultados de Crescimento para Pseudomonas putida sp. em Meio Sintético TSM com Glicose ( $0,50 \%$ p/v) ou Glicerol $(0,50 \%$ p/v)

\begin{tabular}{|c|c|c|c|c|c|}
\hline $\begin{array}{c}\mathrm{pH} \\
\text { inicial }\end{array}$ & $\begin{array}{c}\text { Tempo } \\
\text { (h) }\end{array}$ & $X(g / L)$ & $\begin{array}{c}\text { Glicose } \\
\text { Residual } \\
\text { (g/L) }\end{array}$ & $\begin{array}{l}Y_{x / s} \\
(g / g)\end{array}$ & $\mathrm{pH}$ final \\
\hline \multirow[t]{2}{*}{7} & 0 & 0,003 & 5,0 & - & - \\
\hline & 27 & 0,23 & 3,9 & 0,21 & 3,7 \\
\hline $\begin{array}{c}\text { pH } \\
\text { inicial }\end{array}$ & $\begin{array}{c}\text { Tempo } \\
\text { (h) }\end{array}$ & $X(g / L)$ & $\begin{array}{c}\text { Glicerol } \\
\text { Residual } \\
\text { (g/L) }\end{array}$ & $\begin{array}{l}Y_{x / s} \\
(g / g)\end{array}$ & $\mathrm{pH}$ final \\
\hline \multirow[t]{2}{*}{7} & 0 & 0,003 & 6,24 & - & - \\
\hline & 27 & 0,65 & 5,44 & 0,8 & 5,1 \\
\hline
\end{tabular}

O valor do $\mathrm{pH}$ final no meio de cultivo contendo glicose foi de 3,7, menor do que no meio contendo glicerol, que foi de 5,1. O valor baixo do $\mathrm{pH}$ final no meio com glicose pode ter inibido o crescimento, portanto, pode ser necessária a utilização de meio com tamponamento mais forte. 
5.3.2 Meio sintético TSM com glicose a 0,50\% (p/v) e variadas concentrações de TRIS

Avaliou-se o crescimento de Pseudomonas putida sp. em meio TSM com glicose e diferentes concentrações do tampão TRIS, afim de moderar a redução do $\mathrm{pH}$ do meio ao longo do crescimento.

Estes experimentos resultaram em maior crescimento celular à medida que a concentração do tampão TRIS foi aumentada, até o valor de $X$ de 1,18 g/L no meio contendo 0,25 M de TRIS, conforme se apresenta na Tabela 9. Entretanto, deve-se salientar que nenhuma das condições de cultivo com diferentes concentrações de TRIS resultou no consumo total da glicose, ou seja, o meio de cultivo não promoveu um crescimento bacteriano satisfatório.

Tabela 9 - Crescimento celular de Pseudomonas putida sp. em Meio Sintético TSM com Glicose $(0,50 \%$ p/v) e diferentes concentrações do tampão TRIS

\begin{tabular}{ccccccc}
\hline $\begin{array}{c}\text { pH } \\
\text { inicial }\end{array}$ & Tempo (h) & Tris (M) & $\mathbf{X}(\mathbf{g} / \mathbf{L})$ & $\begin{array}{c}\text { Glicose } \\
\text { Residual } \\
(\mathbf{g} / \mathbf{L})\end{array}$ & $\begin{array}{c}\mathbf{Y}_{\mathbf{x} / \mathbf{s}} \\
\mathbf{( g / g )}\end{array}$ & $\mathbf{p H}$ final \\
\hline 7,00 & 0 & & 0,003 & 5,0 & - & - \\
- & 27 & 0,10 & 0,44 & 3,5 & 0,29 & 3,80 \\
- & 27 & 0,15 & 0,64 & 3,2 & 0,36 & 4,04 \\
- & 27 & 0,20 & 0,92 & 2,3 & 0,34 & 4,36 \\
- & 27 & 0,25 & 1,18 & 1,8 & 0,37 & 4,73 \\
\hline
\end{tabular}

5.3.3 Meio sintético TSM com ureia, glicerol $(0,50 \% \mathrm{v} / \mathrm{v})$ ou glicose $(0,50 \% \mathrm{p} / \mathrm{v})$

Foi realizado um cultivo com o meio TSM contendo ureia na concentração de $0,60 \mathrm{~g} / \mathrm{L}$ como fonte de nitrogênio ao invés de $\mathrm{NH}_{4} \mathrm{Cl}$ a fim de melhorar o controle do $\mathrm{pH}$.

Os resultados de concentração celular, $\mathrm{X}$, obtidos em meio sintético TSM contendo ureia, com glicose $(0,50 \% \mathrm{p} / \mathrm{v})$ ou glicerol $(0,50 \% \mathrm{v} / \mathrm{v})$, encontram-se na Tabela 10. $O$ crescimento não foi satisfatório para as duas fontes de carbono (glicose e glicerol), para as quais o valor de $X$ foi semelhante $0,37 \mathrm{~g} / \mathrm{L}$ com glicose e $0,38 \mathrm{~g} / \mathrm{L}$ com glicerol. Novamente, as fontes de carbono não foram totalmente consumidas, ou seja, o meio de cultivo não promoveu o adequado crescimento da Pseudomonas putida sp.. 
Tabela 10 - Crescimento celular de Pseudomonas putida sp. em Meio Sintético TSM contendo ureia, Glicose $(0,50 \% \mathrm{p} / \mathrm{v})$ ou Glicerol $(0,50 \% \mathrm{p} / \mathrm{v})$

\begin{tabular}{cccccc}
\hline pH inicial & Tempo $(\mathbf{h})$ & $\mathbf{X}(\mathbf{g} / \mathbf{L})$ & $\begin{array}{c}\text { Glicose Residual } \\
(\mathbf{g} / \mathbf{L})\end{array}$ & $\begin{array}{c}\mathbf{Y}_{\mathbf{x} / \mathbf{s}} \\
(\mathbf{g} / \mathbf{g})\end{array}$ & $\mathbf{p H}$ final \\
\hline 7,0 & 0 & 0,003 & 5,0 & - & - \\
& 27 & 0,37 & 3,2 & 0,20 & 3,7
\end{tabular}

\begin{tabular}{cccccc} 
pH inicial & Tempo $(\mathbf{h})$ & $\mathbf{X}(\mathbf{g} / \mathbf{L})$ & $\begin{array}{c}\text { Glicerol Residual } \\
(\mathbf{g} / \mathbf{L})\end{array}$ & $\begin{array}{c}\mathbf{Y}_{\mathbf{x} / \mathbf{s}} \\
(\mathbf{g} / \mathbf{g})\end{array}$ & $\mathbf{p H}$ final \\
\hline 7,0 & 0 & 0,003 & 6,2 & - & - \\
& 27 & 0,38 & 5,4 & 0,45 & 7,3 \\
\hline
\end{tabular}

5.3.4 Meio sintético M9 com ureia, glicerol $(0,50 \% \mathrm{v} / \mathrm{v})$ ou glicose $(0,50 \% \mathrm{p} / \mathrm{v})$

Os experimentos com o meio sintético M9 foram realizados com ureia na concentração de $0,60 \mathrm{~g} / \mathrm{L}$, glicose ou glicerol como fonte de carbono e energia na concentração de $0,50 \%(\mathrm{p} / \mathrm{v})$ para ambos.

Os resultados obtidos para o crescimento não foram satisfatórios, conforme se verifica na Tabela 11, pois, ainda que toda a glicose tenha sido consumida, a concentração celular foi de apenas $0,56 \mathrm{~g} / \mathrm{L}$ correspondendo a um fator de conversão de glicose a células de 0,11 . Em glicerol, não exaurido, $X$ foi de apenas $0,33 \mathrm{~g} / \mathrm{L}$.

Tabela 11 - Crescimento de Pseudomonas putida sp. em Meio Sintético M9-ureia com Glicose $(0,50 \%$ p/v) ou Glicerol $(0,50 \%$ v/v)

\begin{tabular}{cccccc}
\hline $\begin{array}{c}\mathbf{p H} \\
\text { inicial }\end{array}$ & $\begin{array}{c}\text { Tempo } \\
(\mathbf{h})\end{array}$ & $\mathbf{X}(\mathbf{g} / \mathbf{L})$ & $\begin{array}{c}\text { Glicose Residual } \\
(\mathbf{g} / \mathbf{L})\end{array}$ & $\begin{array}{c}\mathbf{Y}_{\mathbf{x} / \mathbf{s}} \\
(\mathbf{g} / \mathbf{g})\end{array}$ & pH final \\
\hline 7,0 & 0 & 0,003 & 5,0 & - & - \\
& 27 & 0,56 & 0,0 & 0,11 & 6,2
\end{tabular}

\begin{tabular}{cccccc}
$\begin{array}{c}\mathbf{p H} \\
\text { inicial }\end{array}$ & $\begin{array}{c}\text { Tempo } \\
\mathbf{( h )}\end{array}$ & $\mathbf{X}(\mathbf{g} / \mathbf{L})$ & $\begin{array}{c}\text { Glicerol Residual } \\
(\mathbf{g} / \mathbf{L})\end{array}$ & $\begin{array}{c}\mathbf{Y} \mathbf{x} / \mathbf{s} \\
(\mathbf{g} / \mathbf{g})\end{array}$ & $\mathbf{p H}$ final \\
\hline 7,0 & 0 & 0,003 & 6,2 & - & - \\
& 27 & 0,33 & 6,0 & 1,26 & 7,2 \\
\hline
\end{tabular}


5.3.5 Meio sintético M63 com glicerol $(0,50 \% \mathrm{p} / \mathrm{v})$ ou glicose $(0,50 \% \mathrm{p} / \mathrm{v})$

Foi avaliado o meio sintético M63 (WOLFGANG et al., 2004; NINGTHOUJAM et al., 2008) para as duas fontes de carbono (glicose ou glicerol) em pH 7,0.

Quando da utilização de glicose foi obtido $X$ de $0,57 \mathrm{~g} / \mathrm{L}$ e para glicerol $X$ foi de $0,36 \mathrm{~g} / \mathrm{L}$. Os resultados estão apresentados nas Tabela 12. Os valores residuais de glicose e glicerol foram elevados, e, portanto, o meio de cultivo M63 não propiciou o adequado crescimento de $P$. putida sp.

Tabela 12 - Crescimento de Pseudomonas putida sp. em Meio Sintético M63 com Glicose $(0,50 \% \mathrm{p} / \mathrm{v})$ ou Glicerol $(0,50 \% \mathrm{p} / \mathrm{v})$

\begin{tabular}{|c|c|c|c|c|c|}
\hline $\begin{array}{c}\text { pH } \\
\text { inicial }\end{array}$ & $\begin{array}{c}\text { Tempo } \\
\text { (h) }\end{array}$ & $X(g / L)$ & $\begin{array}{c}\text { Glicose } \\
\text { Residual } \\
\text { (g/L) }\end{array}$ & $\begin{array}{l}Y_{x / s} \\
(g / g)\end{array}$ & $\mathrm{pH}$ final \\
\hline 7,00 & 0 & 0,003 & 5,0 & - & - \\
\hline- & 27 & 0,57 & 4,2 & 0,76 & 6,81 \\
\hline $\begin{array}{c}\text { pH } \\
\text { inicial }\end{array}$ & $\begin{array}{c}\text { Tempo } \\
\text { (h) }\end{array}$ & $X(g / L)$ & $\begin{array}{c}\text { Glicerol } \\
\text { Residual } \\
\text { (g/L) }\end{array}$ & $\begin{array}{l}Y_{x / s} \\
(g / g)\end{array}$ & $\mathrm{pH}$ final \\
\hline - & 0 & 0,003 & 5,2 & - & - \\
\hline 7,00 & 27 & 0,36 & 4,9 & 0,66 & 6,85 \\
\hline
\end{tabular}

5.3.6 Meio sintético Ramsay 2006-1 com glicose $(0,50 \% \mathrm{p} / \mathrm{v})$

O meio Ramsay 2006-1 é descrito por diversos autores para o cultivo de bactérias do gênero Pseudomonas (SUN et al., 2006; TACIRO, 2008). Avaliou-se o meio Ramsay 2006-1 adicionado de diferentes concentrações de sulfato de amônio, a saber, $0,50,2,35$ e $4,70 \mathrm{~g} / \mathrm{L}$.

De acordo com os resultados da Tabela 13, $\mathrm{X}$ e $\mathrm{Y}_{\mathrm{X} / \mathrm{S}}$ foram praticamente os mesmos para as concentrações de sulfato de amônio de 4,70 g/L e 2,35 g/L, ou seja, a concentração de 4,70 $\mathrm{g} / \mathrm{L}$ está em excesso em relação à concentração de glicose utilizada. Apesar da glicose ter sido completamente consumida no meio com 0,50 $\mathrm{g} / \mathrm{L}$ de sulfato de amônio, o $\mathrm{Y}_{\mathrm{X} / \mathrm{S}}$ foi o menor para todas as condições. Neste meio de cultivo, em todas as condições avaliadas, a glicose foi exaurida, ou seja, o meio indica-se adequado para o crescimento da bactéria. 
Tabela 13 - Crescimento de Pseudomonas putida sp. em Meio Ramsay 2006-1 com Glicose $(0,50 \% \mathrm{p} / \mathrm{v})$

\begin{tabular}{ccccccc}
\hline $\begin{array}{c}\left(\mathbf{N H}_{\mathbf{4}} \mathbf{2}_{\mathbf{2}} \mathbf{S O}_{\mathbf{4}}\right. \\
\mathbf{( g / L )}\end{array}$ & $\begin{array}{c}\mathbf{p H} \\
\text { inicial }\end{array}$ & $\begin{array}{c}\text { Tempo } \\
\mathbf{( h )}\end{array}$ & $\begin{array}{c}\mathbf{X} \\
\mathbf{( g / L )}\end{array}$ & $\begin{array}{c}\text { Glicose } \\
(\mathbf{g} / \mathbf{L})\end{array}$ & $\begin{array}{c}\mathbf{Y}_{\mathbf{x} / \mathbf{s}} \\
\mathbf{( g / g )}\end{array}$ & pH final \\
\hline & - & 0 & 0,003 & 5,0 & - & - \\
4,70 & 7,00 & 24 & 2,0 & 0,0 & 0,40 & 6,61 \\
2,35 & 7,00 & 24 & 2,1 & 0,0 & 0,41 & 6,62 \\
0,50 & 7,00 & 24 & 1,0 & 0,0 & 0,20 & 6,58 \\
\hline
\end{tabular}

A concentração de $2,35 \mathrm{~g} / \mathrm{L}$ de sulfato de amônio foi aplicada no item seguinte, utilizando-se glicerol como fonte de carbono.

5.3.7 Meio sintético Ramsay 2006-2 contendo glicose $(0,50 \%$ p/v) e glicerol $(0,50 \%$ $p / v)$

No meio sintético Ramsay 2006-1 há uma alta concentração de fosfatos, 9,54 $\mathrm{g} / \mathrm{L}$ de $\mathrm{Na}_{2} \mathrm{HPO}_{4}$ e 4,05 de $\mathrm{KH}_{2} \mathrm{PO}_{4}$. Avaliou-se então outro meio sintético, Ramsay 2006-2, o qual contêm concentrações menores dos fosfatos, a saber, 4,77 g/L de $\mathrm{Na}_{2} \mathrm{HPO}_{4}$ e 2,03 de $\mathrm{KH}_{2} \mathrm{PO}_{4}$. A fonte de nitrogênio foi sulfato de amônio a 2,35 g/L conforme definido no item anterior.

Os resultados obtidos para o meio sintético Ramsay 2006-2 contendo glicose foram bastante semelhantes àqueles obtidos no experimento anterior, no qual a concentração celular atingiu o valor de 1,99 g/L para o meio Ramsay 2006-2 e 1,95 g/L para o meio Ramsay 2006-1. Os valores de $Y_{X / S}$ foram praticamente iguais, uma vez que a de glicose foi completamente consumida, conforme se verifica na Tabela 13.

O resultado do crescimento utilizando glicerol, em 24 horas, foi menor, quando comparado com os meios que continham glicose, pois $X$ foi de $0,66 \mathrm{~g} / \mathrm{L}$ no meio Ramsay 2006-2. Em ambos os meios de cultivo a concentração residual de glicerol foi elevada conforme se verifica na Tabela 14. 
Tabela 14 - Crescimento de Pseudomonas putida sp. em Meio Ramsay 2006-1 e Ramsay 2006-2 com Glicose (0,50\% p/v) e Glicerol (0,50\% p/v) - 24 horas

\begin{tabular}{|c|c|c|c|c|c|}
\hline Meio & $\begin{array}{c}\mathrm{pH} \\
\text { inicial }\end{array}$ & $X(g / L)$ & $\begin{array}{c}\text { Glicose } \\
\text { Residual (g/L) }\end{array}$ & $Y_{x / s}(g / g)$ & $\mathrm{pH}$ final \\
\hline & - & 0,003 & 5,00 & - & - \\
\hline Ramsay 2006 - 1 & 7,00 & 2,0 & 0 & 0,39 & 6,64 \\
\hline Ramsay $2006-2$ & 7,00 & 2,0 & 0 & 0,40 & 6,28 \\
\hline Meio & $\begin{array}{c}\text { pH } \\
\text { inicial }\end{array}$ & $X(g / L)$ & $\begin{array}{c}\text { Glicerol } \\
\text { Residual (g/L) }\end{array}$ & $Y_{x / s}(g / g)$ & $\mathrm{pH}$ final \\
\hline & - & 0,003 & 5,2 & - & - \\
\hline Ramsay 2006 - 1 & 7,00 & 0,4 & 4,6 & 0,62 & 6,71 \\
\hline Ramsay 2006 -2 & 7,00 & 0,7 & 4,2 & 0,66 & 6,61 \\
\hline
\end{tabular}

Já os cultivos contendo glicerol foram estendidos até 48 e apresentaram bons resultados, pois se atingiu $X$ de 2,60 g/L para o meio Ramsay 2006-1 e 2,70 g/L para o meio Ramsay 2006-2, propiciando valores de $Y_{x / S}$ de ordem de 0,50 g/g de glicerol conforme verifica-se na Tabela 15. Deve-se salientar a fonte de carbono, glicerol, foi totalmente consumida, ou seja, o meio de cultivo mostrou-se adequado para o crescimento bacteriano.

Tabela 15 - Crescimento de Pseudomonas putida sp. em Meio Ramsay 2006-1 e Ramsay $2006-2$ com Glicerol $(0,50 \%$ p/v $)-48$ horas

\begin{tabular}{cccccc}
\hline Meio & $\begin{array}{c}\text { pH } \\
\text { inicial }\end{array}$ & $\mathbf{X}(\mathbf{g} / \mathbf{L})$ & $\begin{array}{c}\text { Glicerol } \\
\text { Residual }(\mathbf{g} / \mathbf{L})\end{array}$ & Yx/s & pH final \\
\hline Ramsay 2006-1 & - & 0,003 & 5,2 & - & - \\
Ramsay 2006-2 & 7,00 & 2,6 & 0,0 & 0,50 & 5,65 \\
\hline
\end{tabular}

O crescimento celular lento na presença de glicerol pode ser atribuído à necessidade da produção de enzimas necessárias para a degradação do glicerol, tais como a glicerol quinase e glicerol-3-fosfato dehidrogenase conforme descrito na Revisão Bibliográfica. Estas enzimas são necessárias para a conversão de glicerol em dihidroxiacetona fosfato, que posteriormente pode ser metabolizada pela via glicolítica, diferentemente da glicose, que é facilmente metabolizada pela via 
glicolítica.

5.3.8 Resumo dos resultados dos cultivos de P. putida sp nos meios Ramsay, M63, M9 e TSM

Na Figura 9 apresentam-se os resultados de concentração celular para todos os meios de cultivo nos quais a bactéria $P$. putida sp. foi cultivada. Para o meio de cultivo no qual se obteve a maior concentração celular, meio Ramsay 2006-2 com 2,35 $\mathrm{g}$ de $\left(\mathrm{NH}_{4}\right)_{2} \mathrm{SO}_{4}$ contendo glicose ou glicerol, determinou-se a cinética de crescimento (5.3.9).

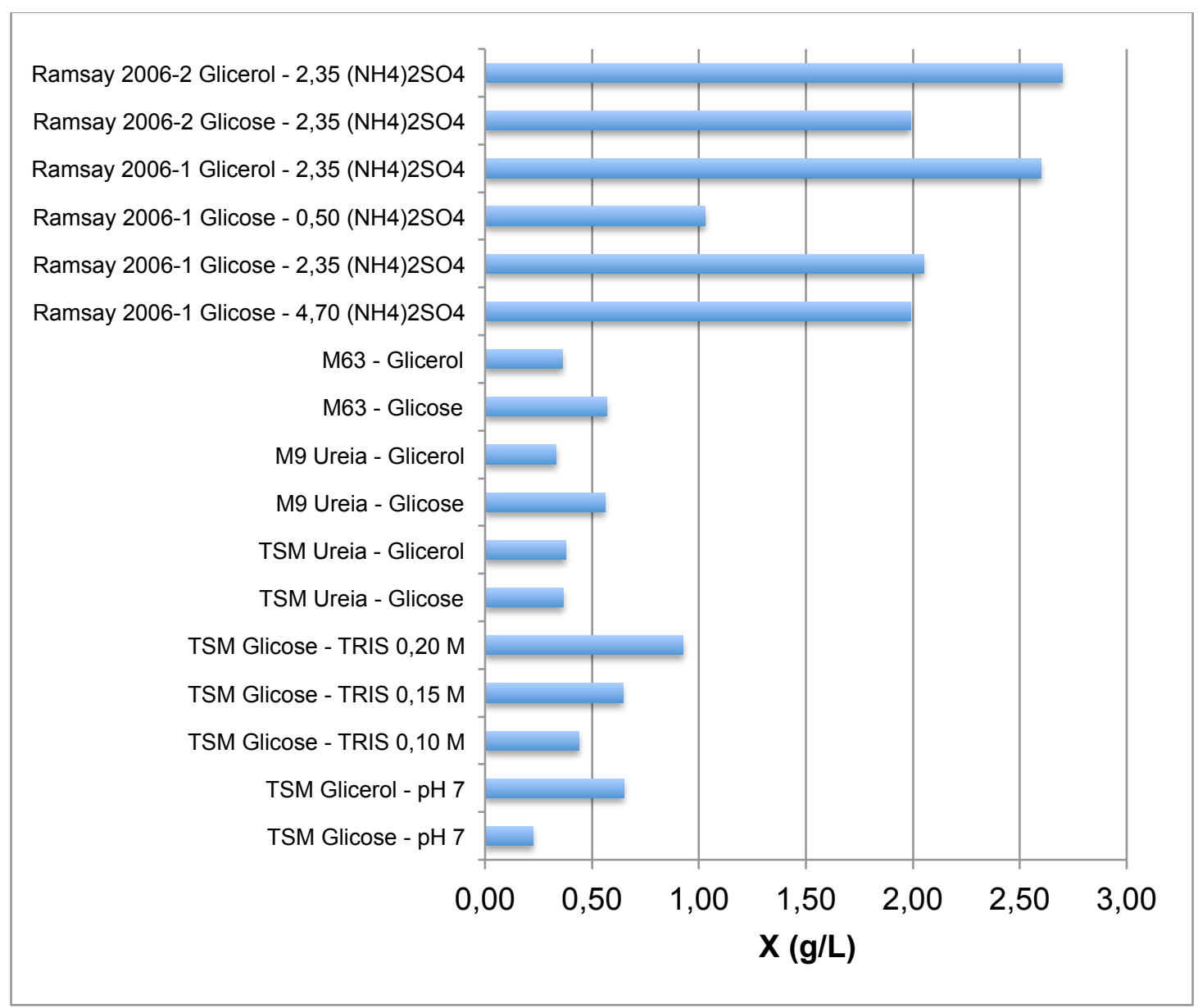

Figura 9 - Crescimento celular de Pseudomonas putida sp nos meios de cultivo Ramsay 2006-2, 2006-1, M63, M9 e TSM 
5.3.9 Cinética do Crescimento em meio sintético Ramsay 2006-2 com glicose $(0,50 \% \mathrm{p} / \mathrm{v})$

A cinética de crescimento em meio sintético Ramsay 2006-2 com glicose apresentou uma fase de crescimento, lento até 8 horas de cultivo, e fase exponencial no intervalo de 9 a 13 horas. O maior valor de concentração celular, $X$, foi de $2,025 \pm 0,018 \mathrm{~g} / \mathrm{L}$, atingido em 22 horas de cultivo, conforme se verifica na Figura 10.

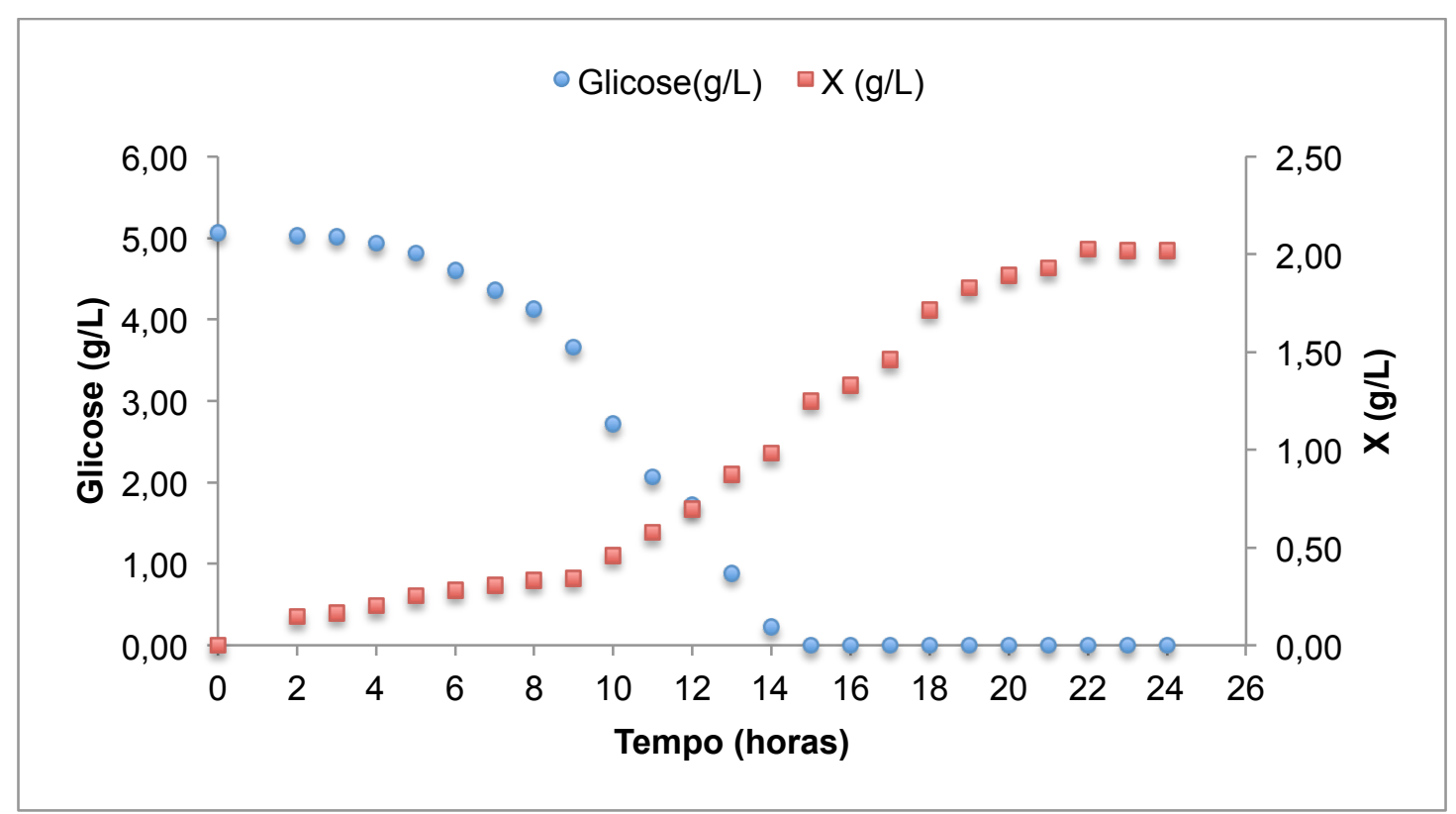

Figura 10 - Concentração de células e de glicose no cultivo da Pseudomonas putida em meio sintético Ramsay 2006-2

O valor do $\mu_{\text {máx }}$ de $0,23 \mathrm{~h}^{-1}$ foi calculado através da regressão linear de $\ln \left(X / X_{0}\right)$ em função do tempo, Figuras 11 e 12, e o valor de $Y_{X / S}$ foi de 0,245 $\pm 0,005$ em 15 horas, instante no qual se verifica exaustão da glicose. 


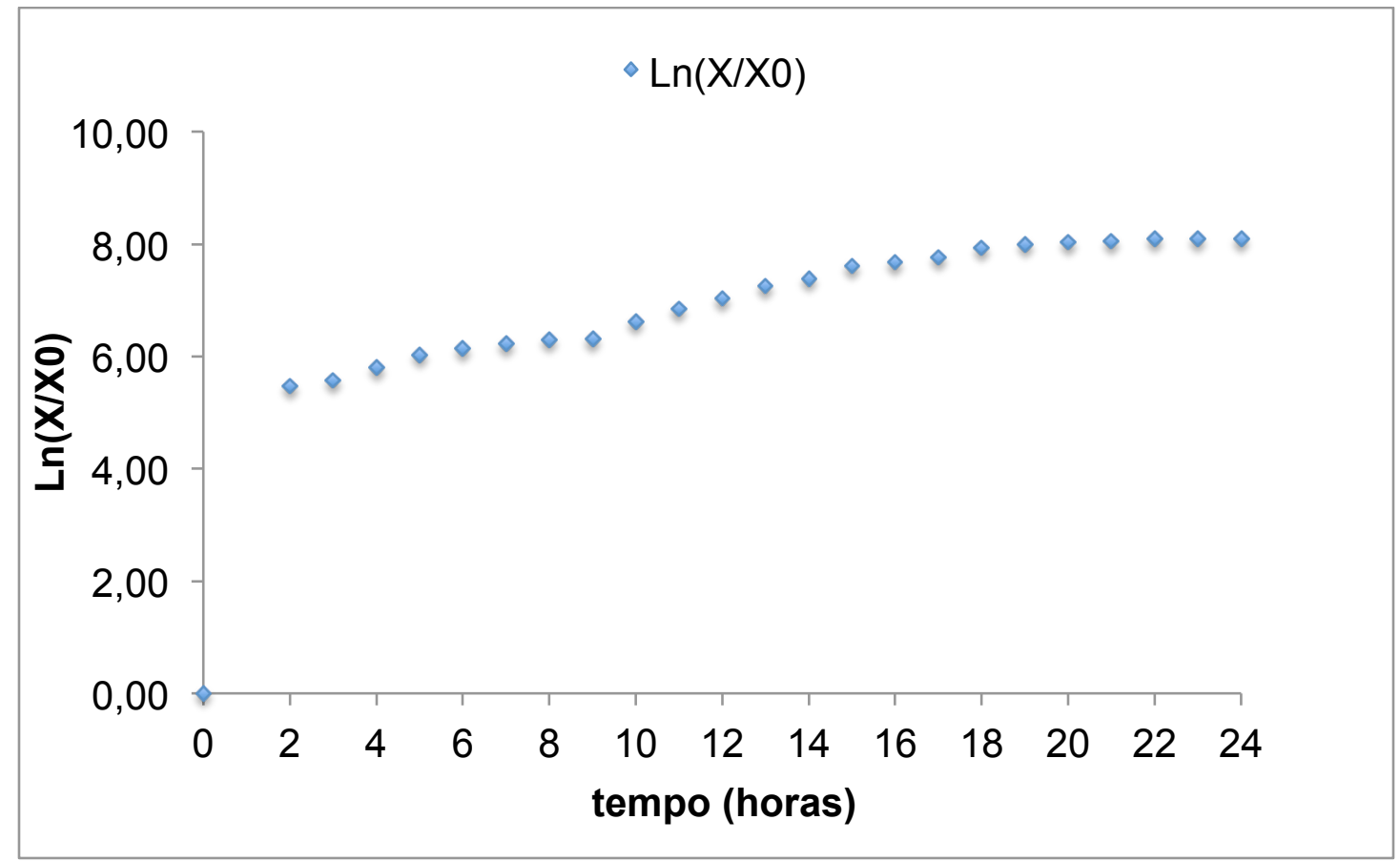

Figura 11 - $\operatorname{Ln}\left(\mathrm{X} / \mathrm{X}_{0}\right)$ em função do tempo, no cultivo de Pseudomonas putida sp. em meio Ramsay 2006-2 acrescido de glicose

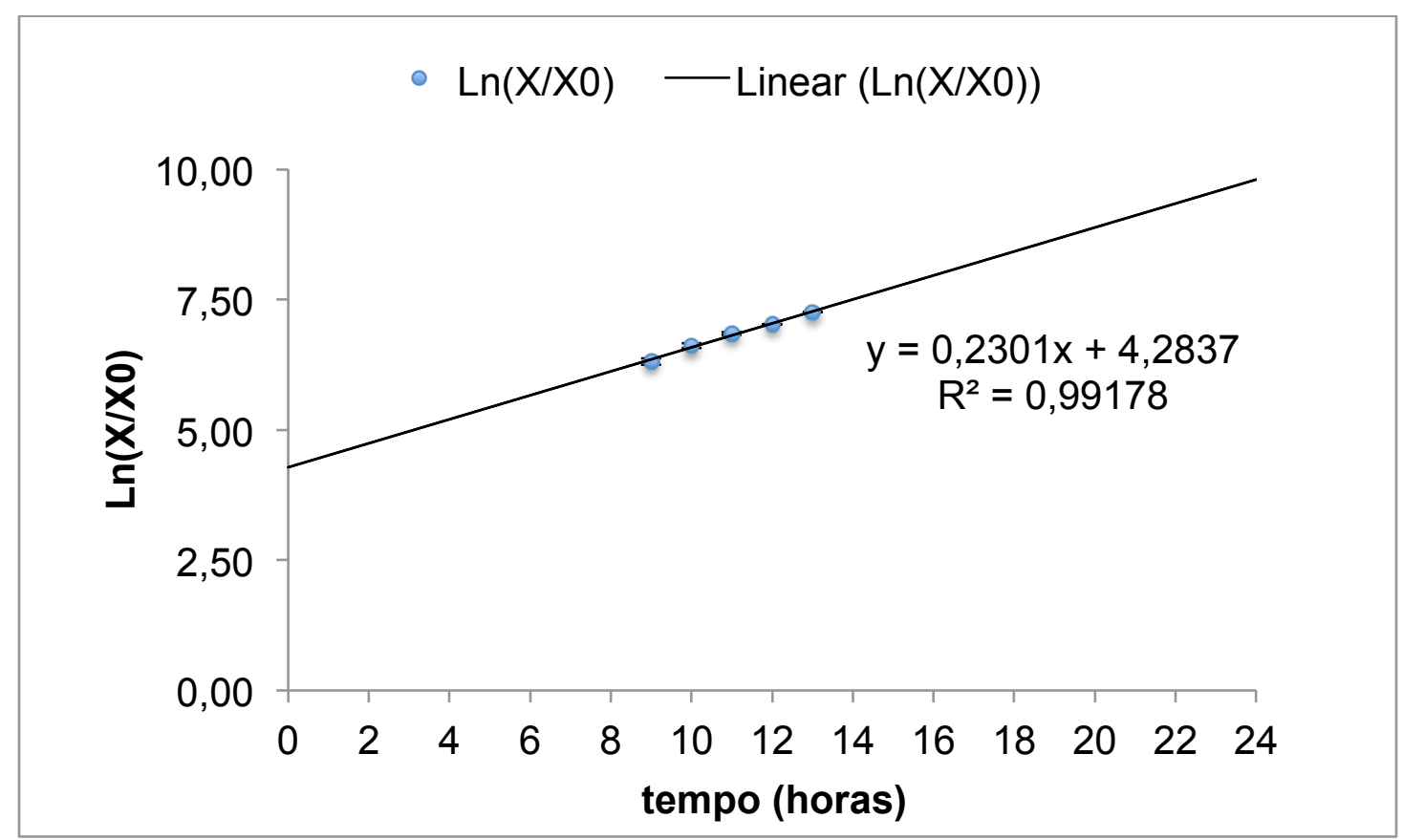

Figura 12 - Regressão linear de $\operatorname{Ln}\left(X / X_{0}\right)$ em função do tempo, no intervalo entre 9 e 15h, no cultivo de Pseudomonas putida sp. em meio Ramsay 2006-2

Deve-se salientar que o crescimento se estendeu até 21 horas, apesar da fonte de carbono ter sido exaurida em 15 horas. Uma hipótese para este crescimento é consumo de metabólitos ácidos gerados e/ou outros produtos altamente energético que pode ser produzidos por bactérias do gênero 
Pseudomonas.

5.3.10 Cinética do Crescimento em meio sintético Ramsay 2006-2 com glicerol $(0,50 \% \mathrm{p} / \mathrm{v})$

A cinética de crescimento em meio sintético Ramsay 2006-2 com glicerol apresentou uma fase de crescimento lenta até 24 horas de cultivo e a fase exponencial ocorreu de 27 a 33 horas do cultivo. O máximo valor de concentração celular, $\mathrm{X}$, foi de $2,775 \pm 0,018 \mathrm{~g} / \mathrm{L}$ em 42 horas de cultivo, conforme se verifica na Figura 13.

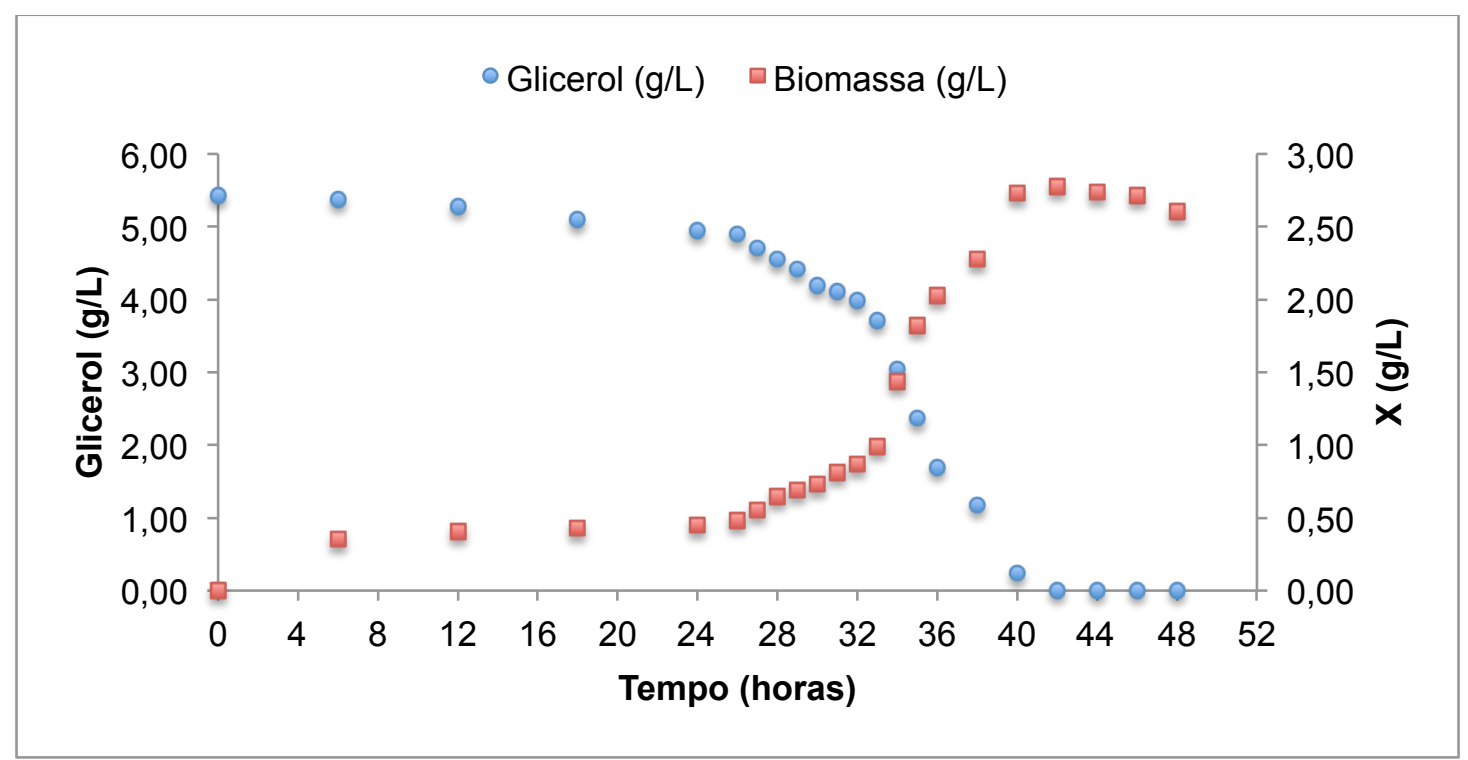

Figura 13 - Concentração de células e de glicerol no cultivo de Pseudomonas putida sp em meio sintético Ramsay 2006-2

$\mathrm{O}$ valor do $\mu_{\text {máx }}$ de $0,10 \mathrm{~h}^{-1}$ foi calculado através da regressão linear de $\ln (X / X 0)$ em função do tempo (Figura 14 e 15). Apesar do baixo valor de $\mu_{\max }$, o fator de conversão de glicerol em células $\left(Y_{\mathrm{X} / \mathrm{S}}\right)$ foi elevado, 0,511 \pm 0,005 g/g em 42 horas. 


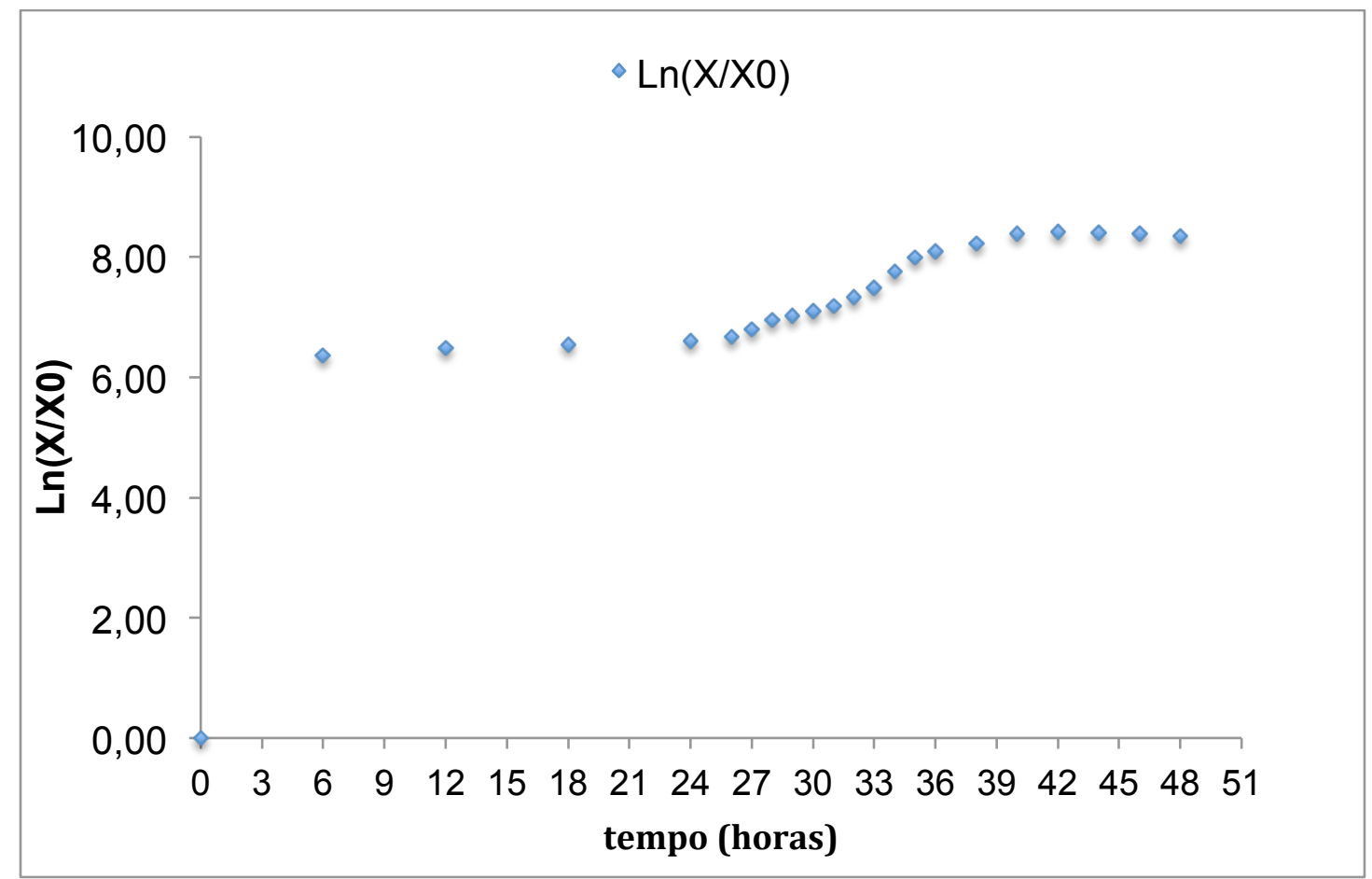

Figura 14 - $\operatorname{Ln}\left(X / X_{0}\right)$ em função do tempo, no cultivo de Pseudomonas putida sp. em meio Ramsay 2006-2 acrescido de glicerol

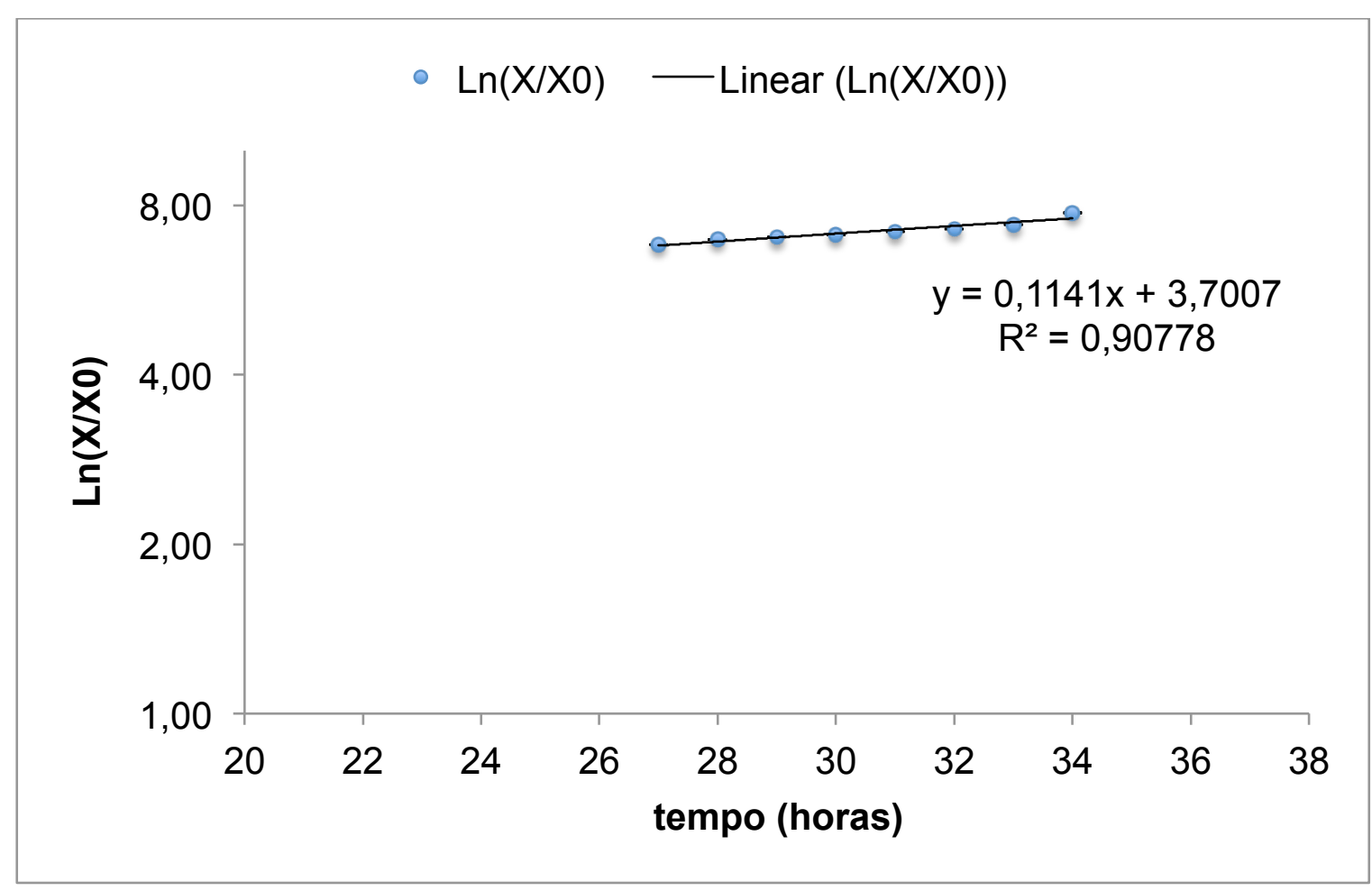

Figura 15 - Regressão linear de $\operatorname{Ln}\left(X / X_{0}\right)$ em função do tempo, no intervalo entre 27 e 33h, no cultivo de Pseudomonas putida sp. em meio Ramsay 2006-2 acrescido de glicerol 


\subsubsection{Cinética do Crescimento em meio sintético MM com glicerol (0,50\% p/v)}

Foram realizados testes de adição de solução de cobre no meio de cultivo Ramsay-2 e foi verificada a precipitação de cobre. Foi necessário realizar cultivo no meio mineral MM, o qual não apresentou precipitação de cobre.

A cinética de crescimento para o meio mineral $\mathrm{MM}$ com a bactéria Pseudomonas putida sp. apresentou fase lag de menor duração na comparação com o meio Ramsay 2006-2. Este resultado não pode ser atribuído somente ao meio, uma vez que a concentração do inóculo foi dez vezes maior, como se verifica na Figura 16. A concentração celular máxima, X, foi de $2,51 \mathrm{~g} / \mathrm{L}$ em 19 horas de cultivo.

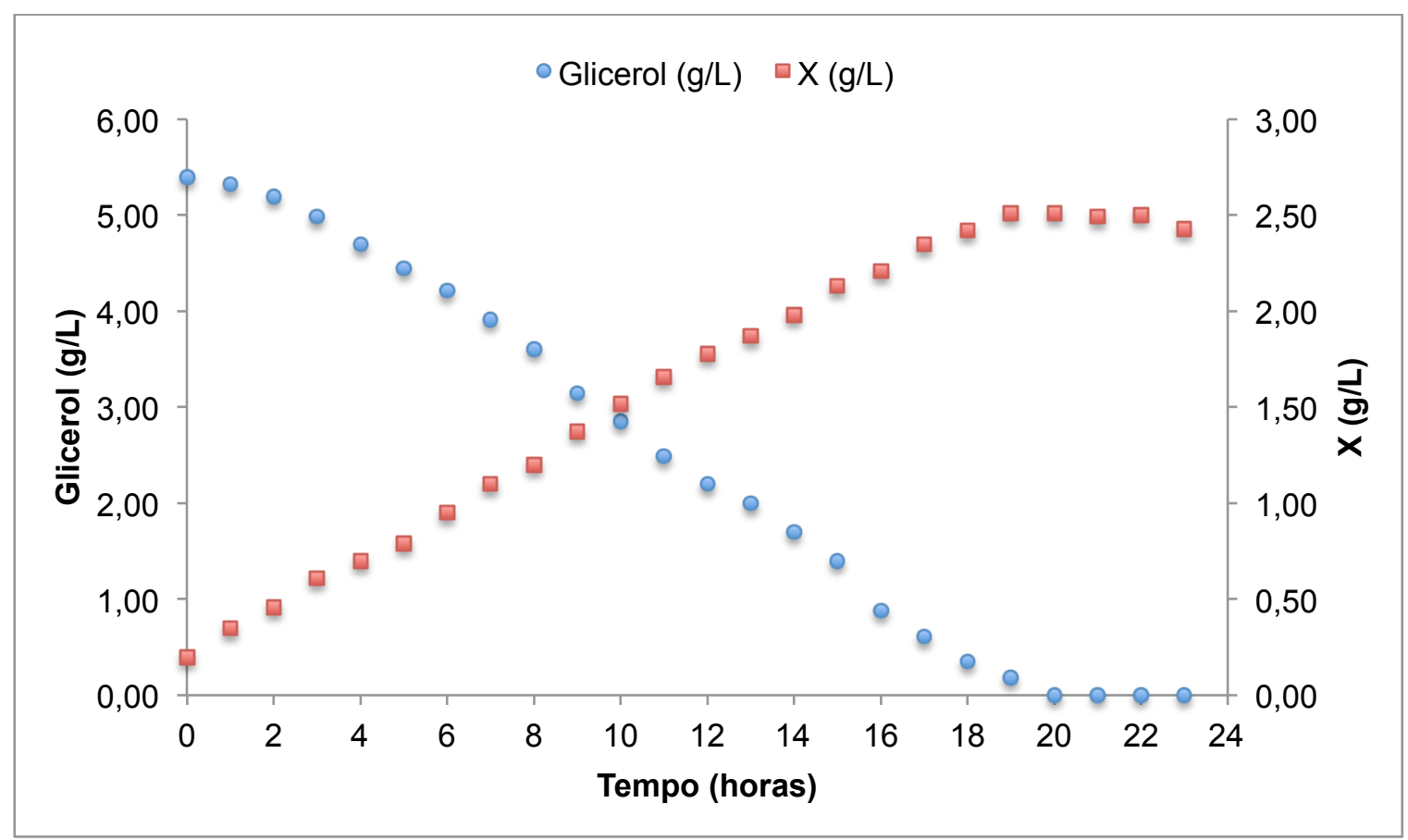

Figura 16 - Concentração de células e glicerol no cultivo de Pseudomonas putida sp. em meio sintético MM acrescido de glicerol

O valor do $\mu_{\text {máx }}$ de $0,11 \mathrm{~h}^{-1}$ que foi calculado através da regressão linear de In(X/X0) em função do tempo (Figura 17 e 18). O fator de conversão de glicerol em células $\left(Y_{X / S}\right)$ foi de $0,46 \mathrm{~g} / \mathrm{g}$ em $12 \mathrm{~h}$. 


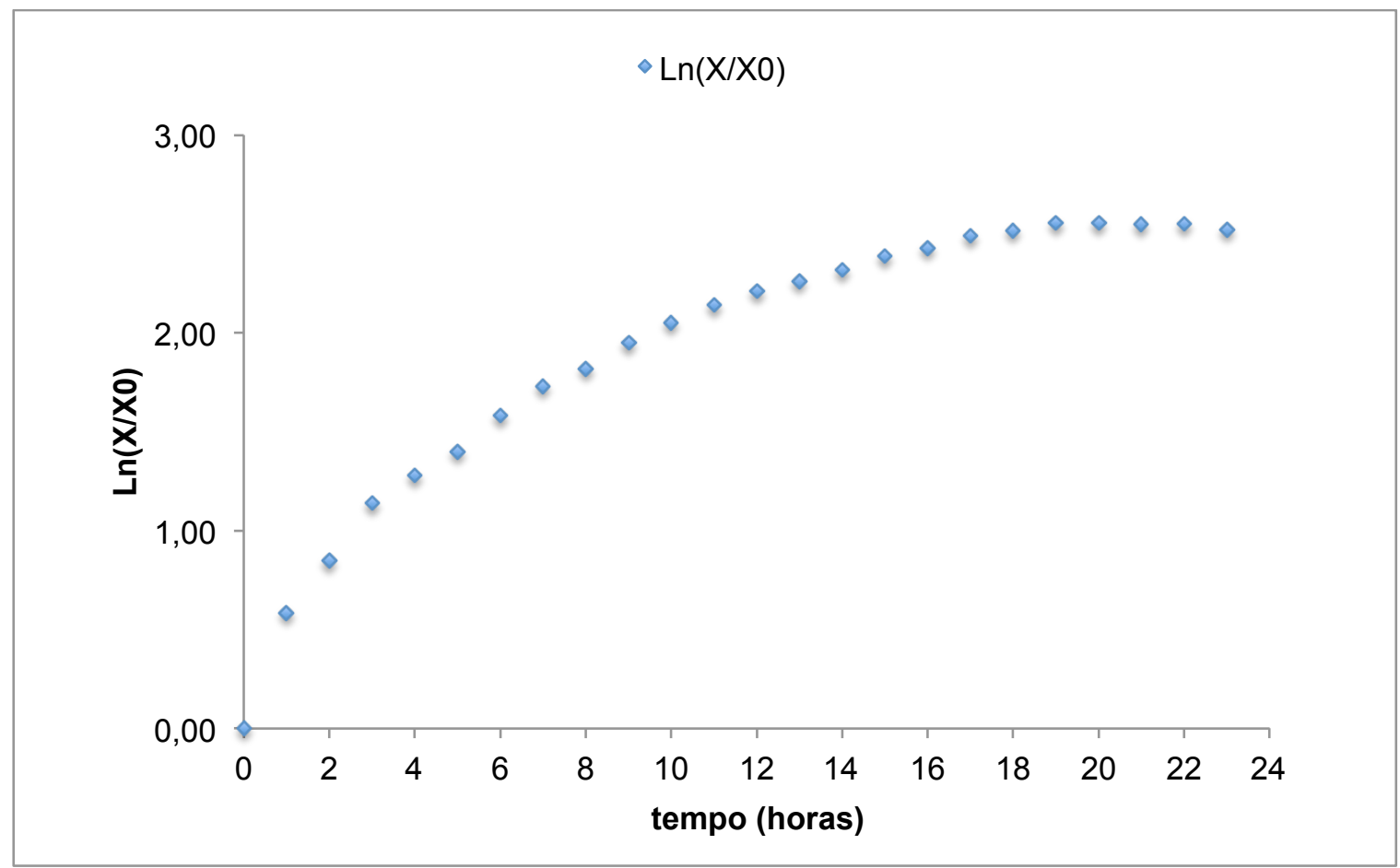

Figura 17 - $\operatorname{Ln}\left(X / X_{0}\right)$ em função do tempo, no cultivo de Pseudomonas putida sp. em meio MM acrescido de glicerol

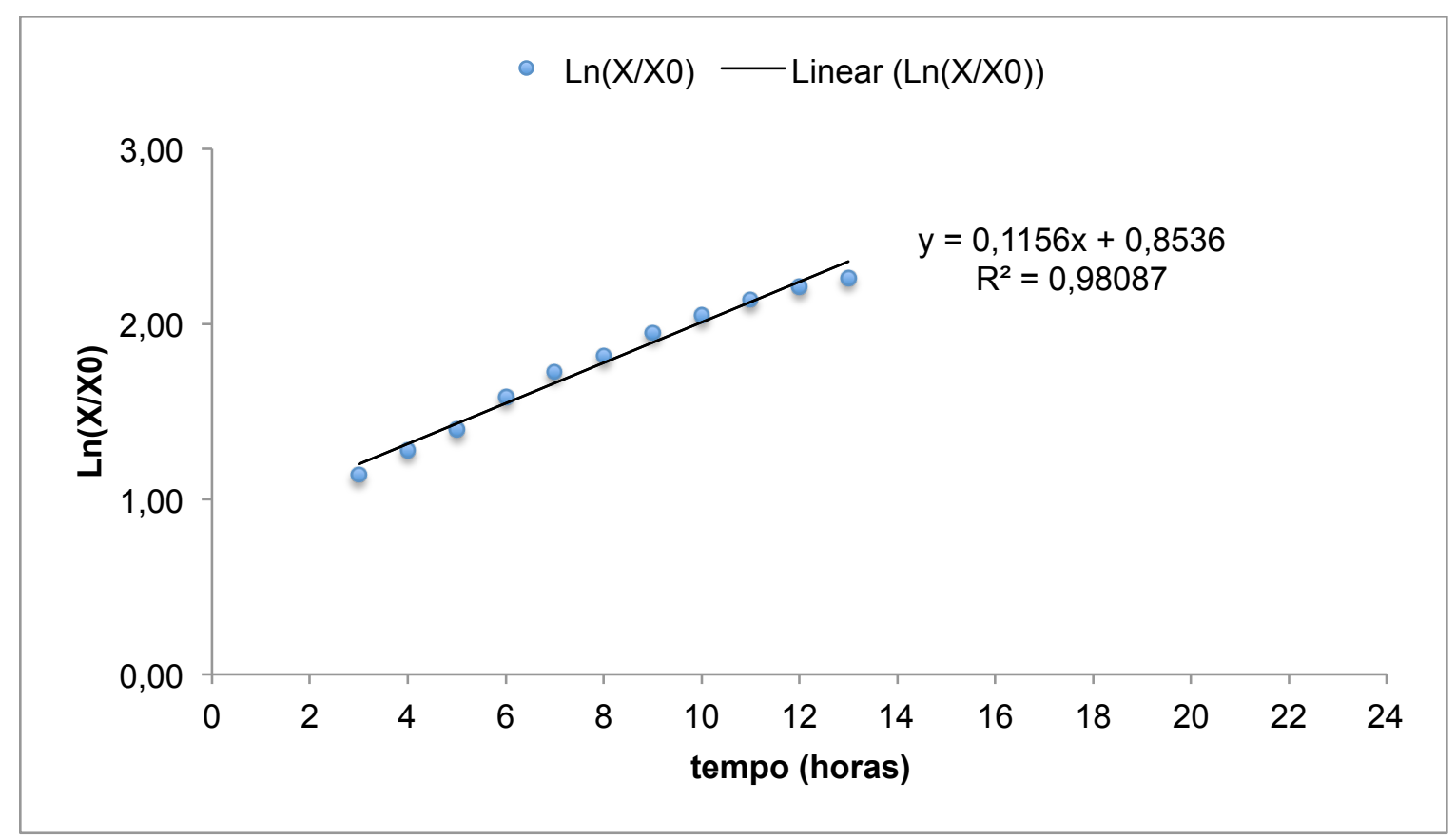

Figura 18 - Regressão linear de $\operatorname{Ln}\left(X / X_{0}\right)$ em função do tempo, no intervalo entre 3 e 13h, no cultivo de Pseudomonas putida sp. em meio MM acrescido de glicerol

O meio MM passou a ser utilizado nos experimentos em reator, pois apresentou crescimento satisfatório e não ocorreu a precipitação de cobre. 


\subsection{Sorção de Cobre e Isoterma de Langmuir}

Foi realizado cultivo com o melhor meio de cultivo para a Pseudomonas putida sp, ou seja, o meio sintético Ramsay - 2006-2, utilizando glicerol como fonte de carbono.

A bactéria foi cultivada até a metade da fase log de crescimento e, então, as células foram coletadas para os experimentos de sorção de cobre (FOSSOKANKEU et al., 2011; HUANG et al., 2003).

\subsubsection{Pseudomonas putida sp.}

São apresentadas na Figura 19 as curvas de massa de cobre sorvida por massa seca de células, $\mathrm{Q}$, em Pseudomonas putida sp., em função do tempo e das quatro concentrações iniciais de cobre aplicadas $(0,119 ; 0,584 ; 1,161$ e 2,06 mM). A máxima sorção de cobre pela bactéria foi de $57,78 \pm 0,10 \mathrm{mg}$ de cobre/g massa seca de células para a condição inicial de 1,161 mM de cobre. Nas curvas de sorção para as concentrações iniciais de 0,$119 ; 0,584 ; 1,161 \mathrm{mM}$ de cobre verificou-se equilíbrio após duas horas de exposição e, para a concentração inicial de 2,060 mM de cobre não foi observado equilíbrio.

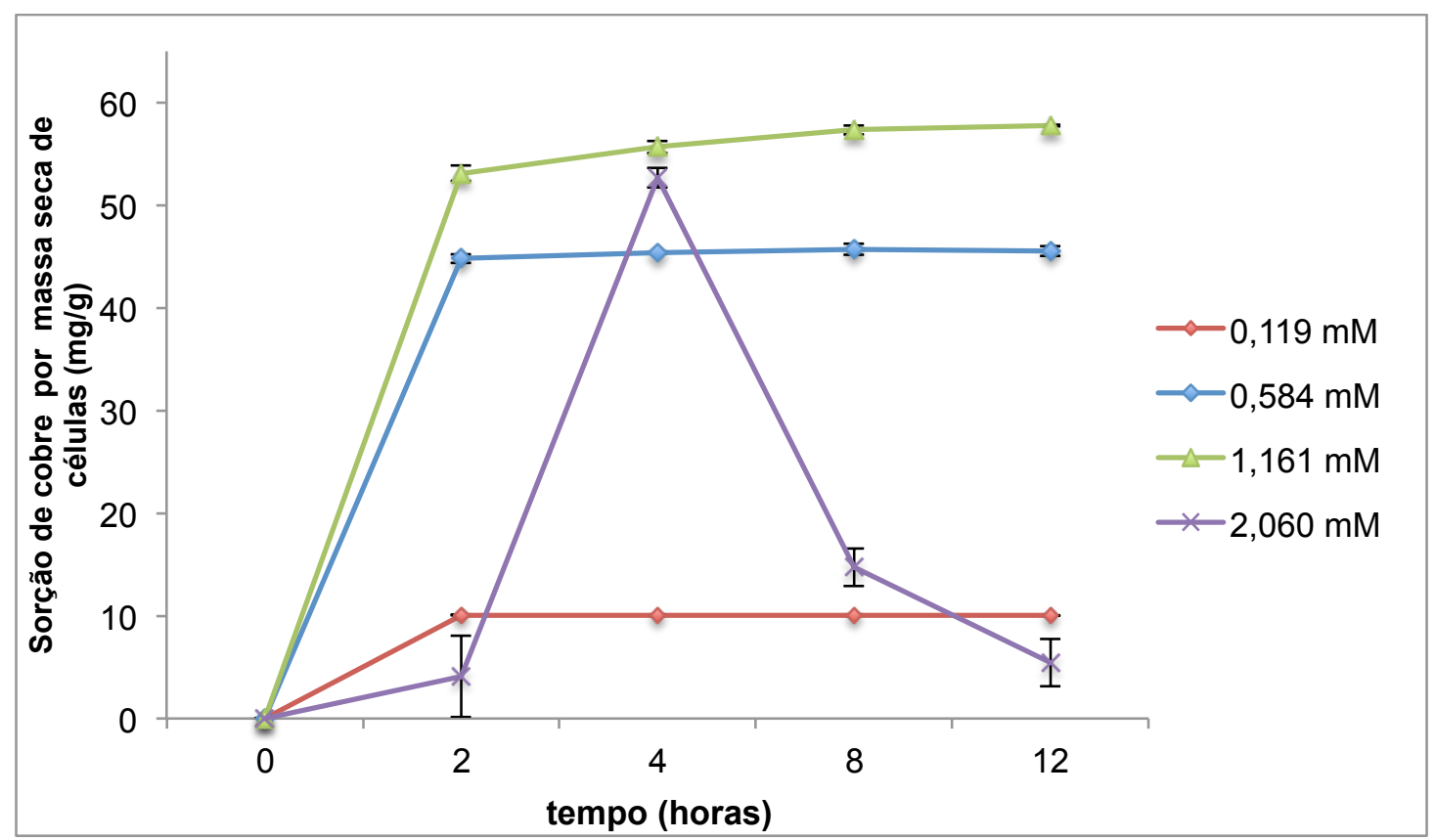

Figura 19 - Sorção de cobre em Pseudomonas putida sp. em função do tempo, a 30 ${ }^{\circ} \mathrm{C}$, em água ultra-pura em $\mathrm{pH} 5$ 
A partir dos resultados de adsorção de cobre por massa seca de células para as diferentes concentrações iniciais de cobre foi possível traçar a isoterma de Langmuir para Pseudomonas putida sp. conforme se verifica na Figura 20.

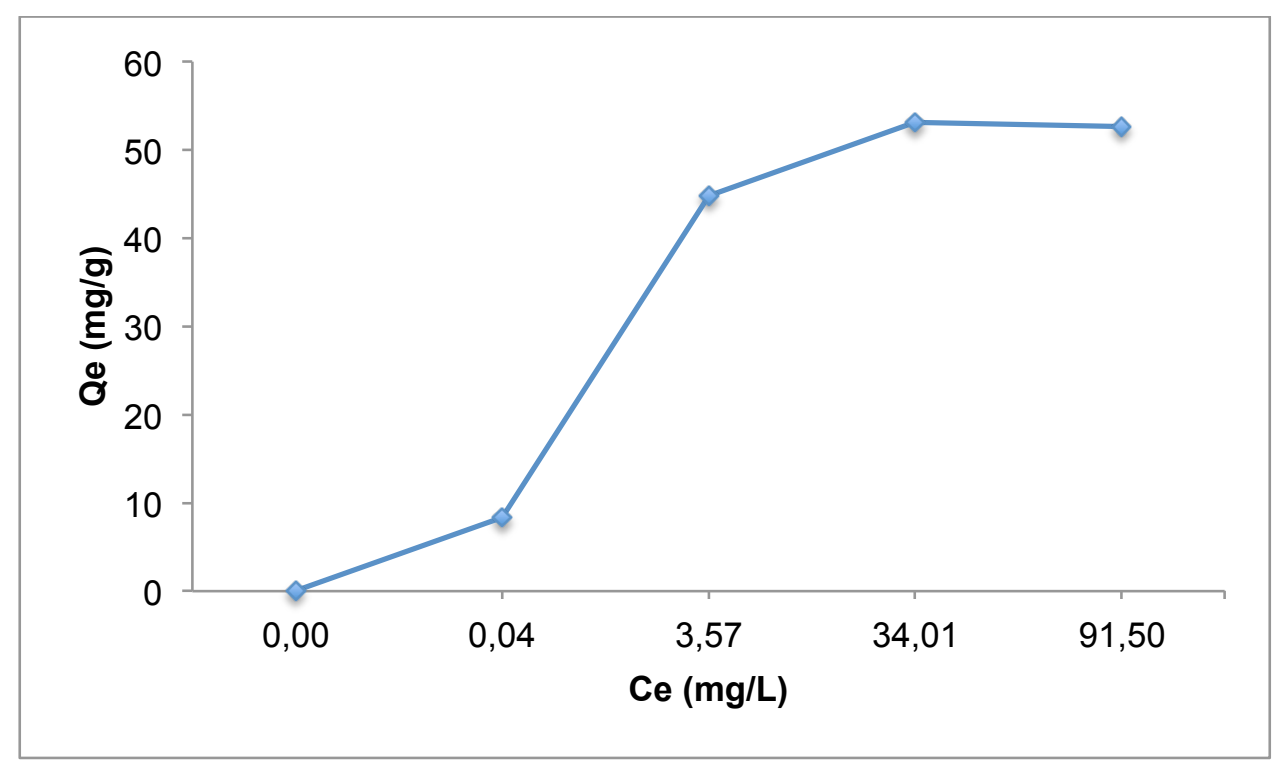

Figura 20 - Sorção de cobre para Pseudomonas putida sp. em diferentes concentrações de cobre. Ce: concentração de metal em equilíbrio na solução; Qe: massa de metal adsorvida por massa de células seca.

Através da regressão linear $\left(R^{2}\right.$ de 0,999$)$ da isoterma de Langmuir foi possível determinar os parâmetros de isoterma, $\mathrm{q}_{\mathrm{m}}$ de $52,91 \mathrm{mg} / \mathrm{g}$ e $\mathrm{k}$ de $2,78 \mathrm{~L} / \mathrm{mg}$.

5.4.2 Resultados de sorção de Pseudomonas putida sp. e dados de literatura

Na Tabela 16 verificam-se os resultados para sorção máxima de cobre por grama de massa seca de células. 
Tabela 16 - Resultados de Sorção de cobre pela Pseudomonas putida sp utilizada neste trabalho e dados de literatura

\begin{tabular}{|c|c|c|}
\hline Bactéria & $\begin{array}{c}\mathrm{Cu}^{+2} \text { Sorvido } \\
\text { (mg/g de } \\
\text { biomassa } \\
\text { seca) }\end{array}$ & Referência \\
\hline Bacillus subtilis & 11,00 & Mayers; Beveridge (1989) \\
\hline Brevibacterium sp. & 34,34 & Vecchio (1998) \\
\hline Bacillus sp. (esporos) & 52,40 & He; Tebo (1998) \\
\hline Pseudomonas aeruginosa & 14,12 & Langley; Beveridge (1999) \\
\hline $\begin{array}{l}\text { Enterobacter aerogenes } \\
\text { NTG-01 }\end{array}$ & 25,12 & Huang; Chen; Xu (2005) \\
\hline Pseudomonas putida CZ1 & 27,20 & Chen et al. (2005) \\
\hline $\begin{array}{l}\text { Cupriavidus taiwanensis } \\
\text { TJ208 }\end{array}$ & 19,00 & Chen et al. (2008) \\
\hline $\begin{array}{l}\text { Pseudomonas putida } \\
\text { (NRRL B-255) }\end{array}$ & 49,50 & Uslu; Tanylol (2006) \\
\hline Bacillus sp. & 16,25 & Tunali; Çabuk; Akar (2006) \\
\hline $\begin{array}{l}\text { Cupriavidus metallidurans } \\
\mathrm{CH} 34\end{array}$ & 38,72 & $\begin{array}{l}\text { Fan; Okayak; Rodrigues, } \\
\text { (2014) }\end{array}$ \\
\hline Pseudomonas putida sp. & 57,78 & Este trabalho \\
\hline
\end{tabular}

\subsection{Cultivo em Regime de Batelada - Ensaio B1}

No Ensaio B1 cultivou-se a bactéria Pseudomonas putida sp. com o objetivo de conhecer a cinética do seu crescimento em reator, meio mineral MM-HCD com 5 g/L de glicerol, no reator Labfors 5, conforme descrito em Materiais e Métodos (4.7).

A Figura 21 apresenta as curvas de concentração celular e glicerol residual ao longo do tempo do cultivo. Glicerol, com concentração inicial de $5,00 \mathrm{~g} / \mathrm{L}$, foi consumido em 16 horas resultando $X$ de $2,90 \mathrm{~g} / \mathrm{L}$. $O$ fator de conversão de glicerol a células, $Y_{x / s}$, foi de $0,49 \mathrm{~g} / \mathrm{g}$, valor próximo ao obtido quando comparado com o valores obtidos por Verhoef et al. (2014), entre 0,43 e 0,54 g/g, para outras linhagens do gênero Pseudomonas. 


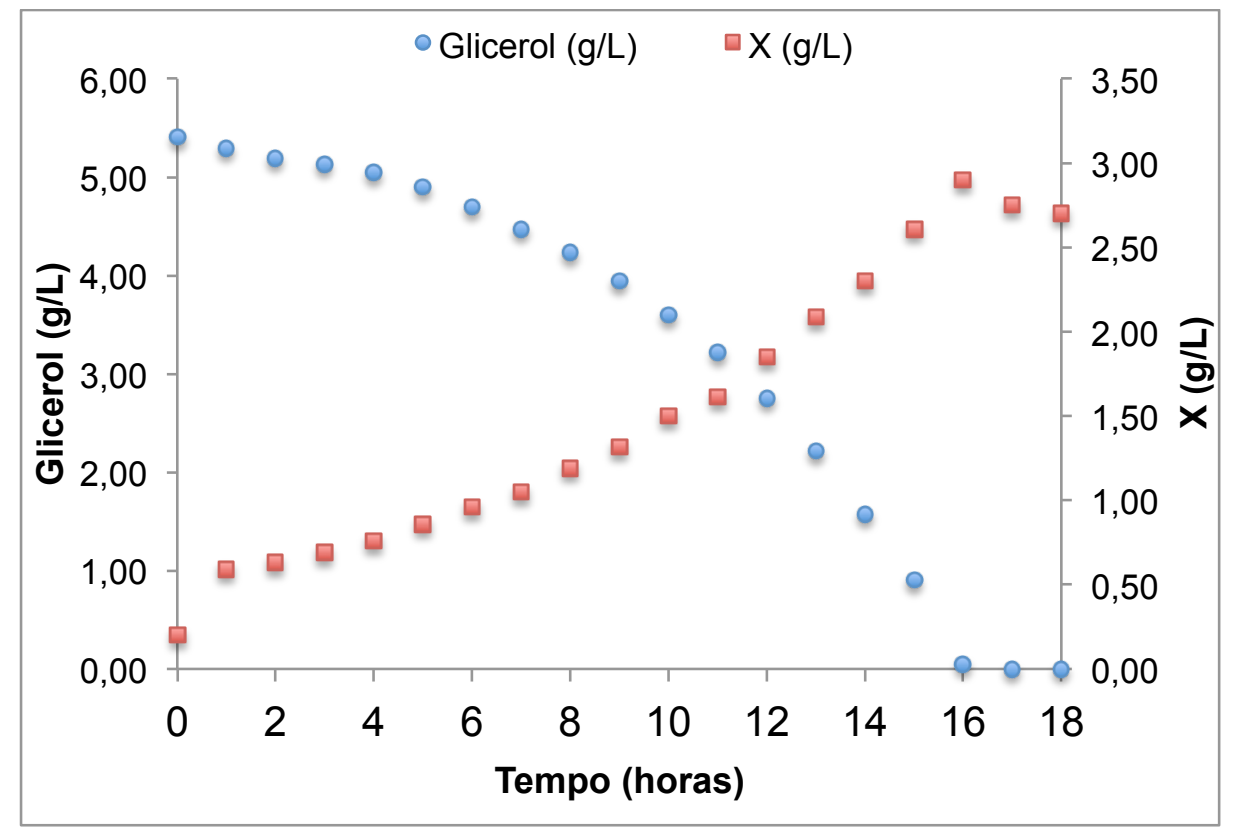

Figura 21 - Concentração de células e glicerol em função do tempo de cultivo de Pseudomonas putida sp. em meio MM-HCD com glicerol, regime de batelada - Ensaio B1.

Determinou-se o valor de $\mu_{\max }$ de $0,11 \mathrm{~h}^{-1}$ através de regressão linear aplicada aos valores de $\ln \left(\mathrm{X} / \mathrm{X}_{0}\right)$, onde $\mathrm{X}_{0}$ refere-se ao valor de $\mathrm{X}$ no instante inicial da fase logarítmica, em função do tempo de cultivo, conforme se apresenta na Figura 22.

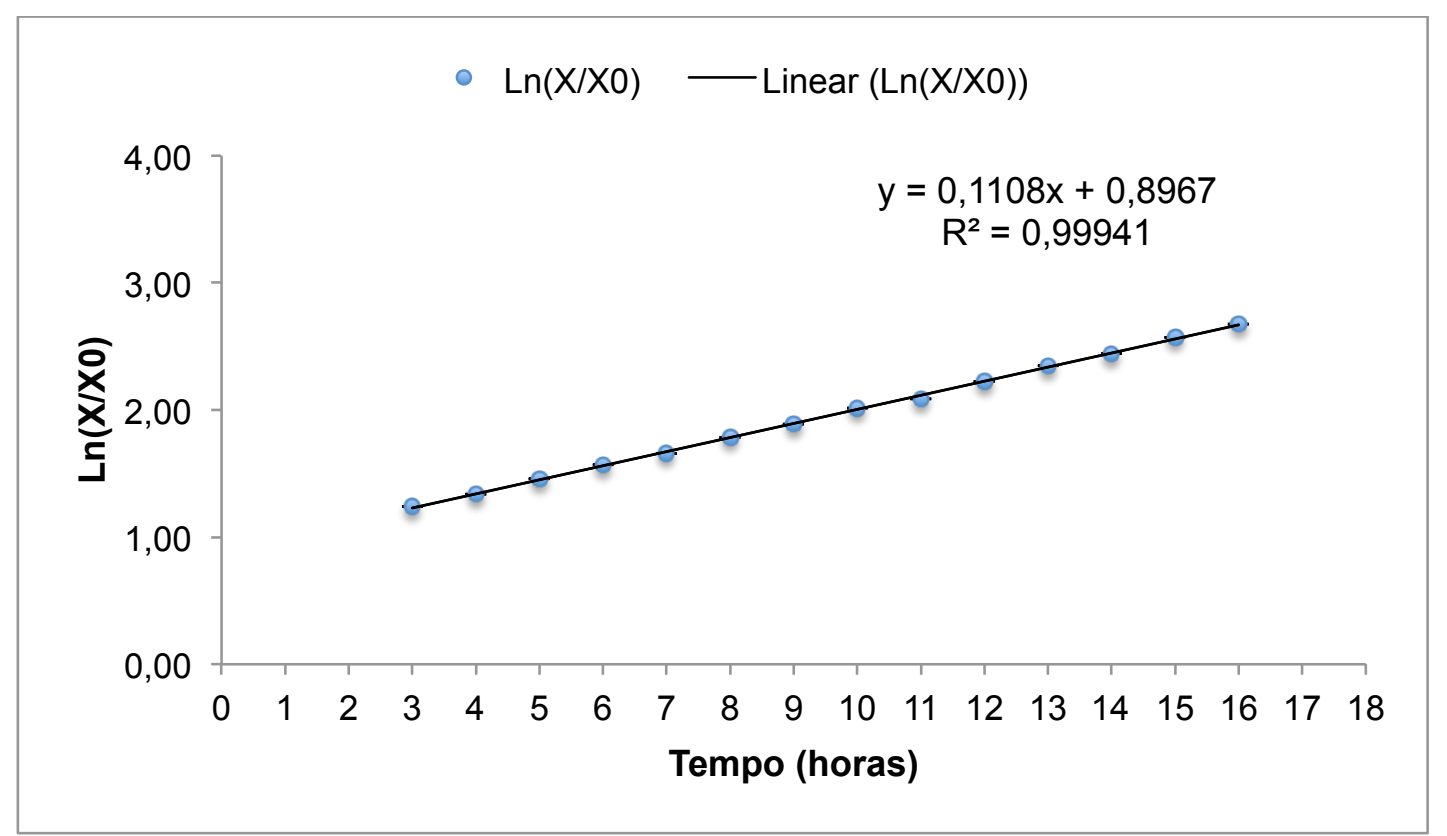

Figura 22 - Regressão linear de $\operatorname{Ln}\left(X / X_{0}\right)$ em função do tempo no intervalo entre 3 e $16 \mathrm{~h}$, no cultivo de Pseudomonas putida sp. em meio MM-HCD com glicerol - Ensaio B1 
O valor de $0,11 \mathrm{~h}^{-1}$ para $\mu_{\max }$ é baixo se comparado a outras linhagens de Pseudomonas putida cultivadas em glicose, como por exemplo a linhagem KT2440 e suas modificações genéticas, que apresentaram valores de $\mu_{\max }$ entre 0,21 - 0,56 $\mathrm{h}^{-1}$ no trabalho de Borrero-De Acuna et al. (2014). No trabalho de Annuar et al. (2006), o valor de $\mu_{\max }$ para Pseudomonas putida PGA1 utilizando glicose foi de 0,17 $\mathrm{h}^{-1}$. Diniz et al. (2004), obtiveram o valor de $0,65 \mathrm{~h}^{-1}$ de $\mu_{\max }$ cultivando a linhagem Pseudomonas putida IPT 046 em frutose e glicose conjuntamente.

A diferença entre $o$ valor de $\mu_{\max }$ em meio a glicose ou glicerol pode ser consequência da rota metabólica adicional necessária ao consumo de glicerol, para subsequente inserção na via glicolítica ou à uma via de gluconeogênese, conforme apresentado na Figura 23.

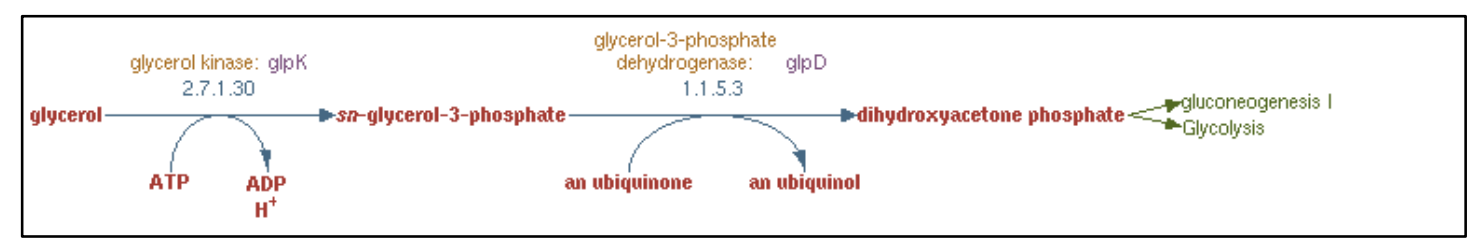

Figura 23 - Rota Metabólica do consumo de glicerol (Fonte: Sítio Keeg Pathway)

\subsection{Cultivos de Pseudomonas putida sp. em Regime de Batelada Alimentada por Pulsos para Alta Densidade Celular}

\subsubsection{Ensaio FB1}

O ensaio FB1 contou com uma primeira etapa em regime de batelada simples, na qual a fonte de carbono e energia, glicerol, na concentração inicial, $S_{0}$, de $30 \mathrm{~g} / \mathrm{L}$, foi consumida em 39 horas de cultivo no meio mineral MM-HCD. A Figura 24 apresenta as curvas de concentração de células e glicerol ao longo do tempo do cultivo. O pulso de alimentação de glicerol e demais nutrientes foi realizado às $39 \mathrm{~h}$ de cultivo, totalizando um aporte de glicerol de $32 \mathrm{~g} / \mathrm{L}$, e subsequente aumento discreto na concentração celular, a qual se estabilizou em torno de $13 \mathrm{~g} / \mathrm{L}$ em 46 horas de cultivo e manteve-se estável até o final do cultivo, em 54 horas. 


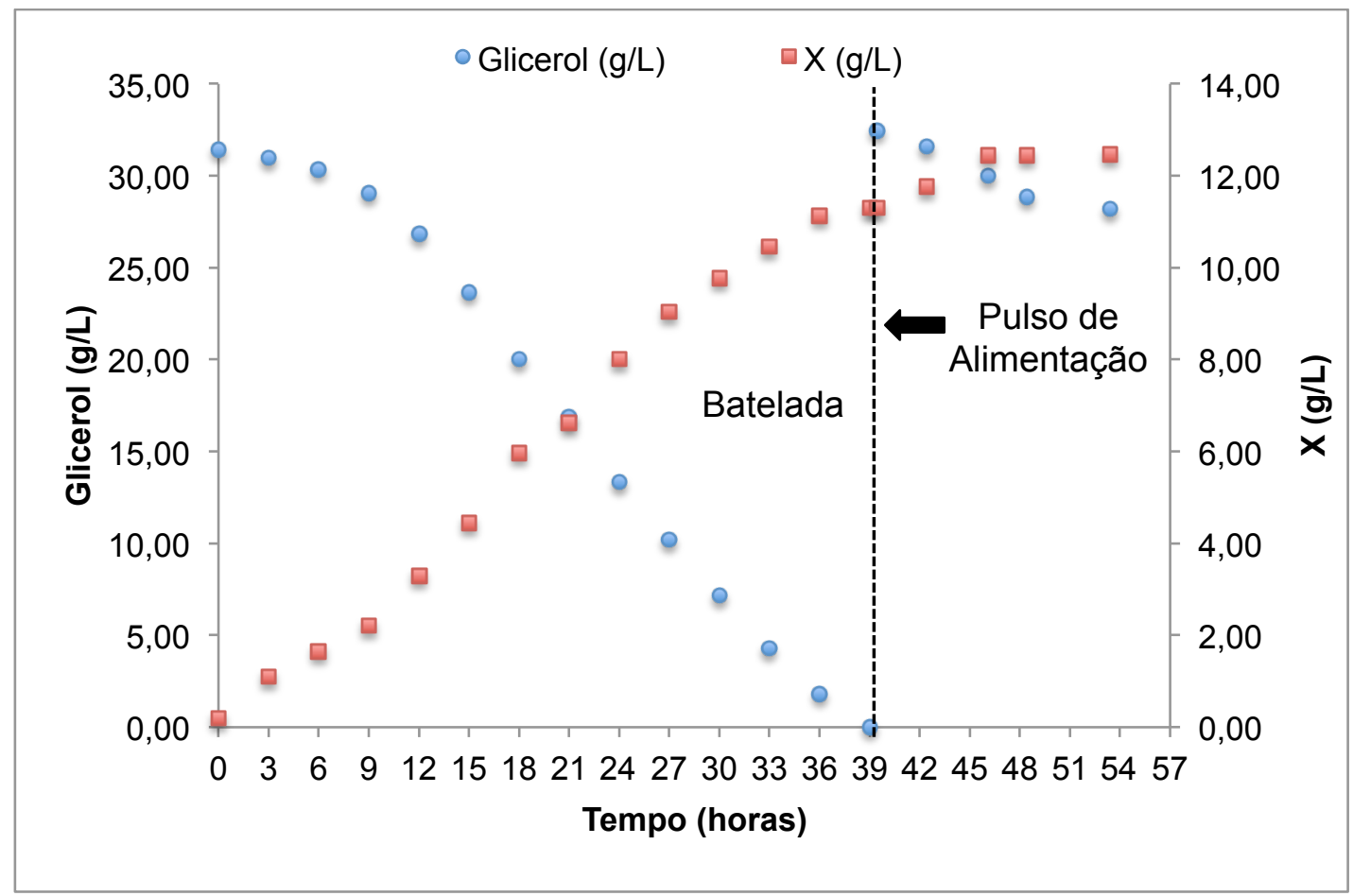

Figura 24 - Concentração de células e glicerol em função do tempo de cultivo de Pseudomonas putida sp. em meio MM-HCD com glicerol, regime de batelada alimentada - Ensaio FB1

A Figura 25 apresenta a regressão linear de $\operatorname{Ln}\left(X / X_{0}\right)$ em função do tempo de cultivo, na qual verifica-se fase de crescimento exponencial para o intervalo entre 3 e 18 horas e nulidade da velocidade de crescimento bacteriano por volta de 36 horas de cultivo. 


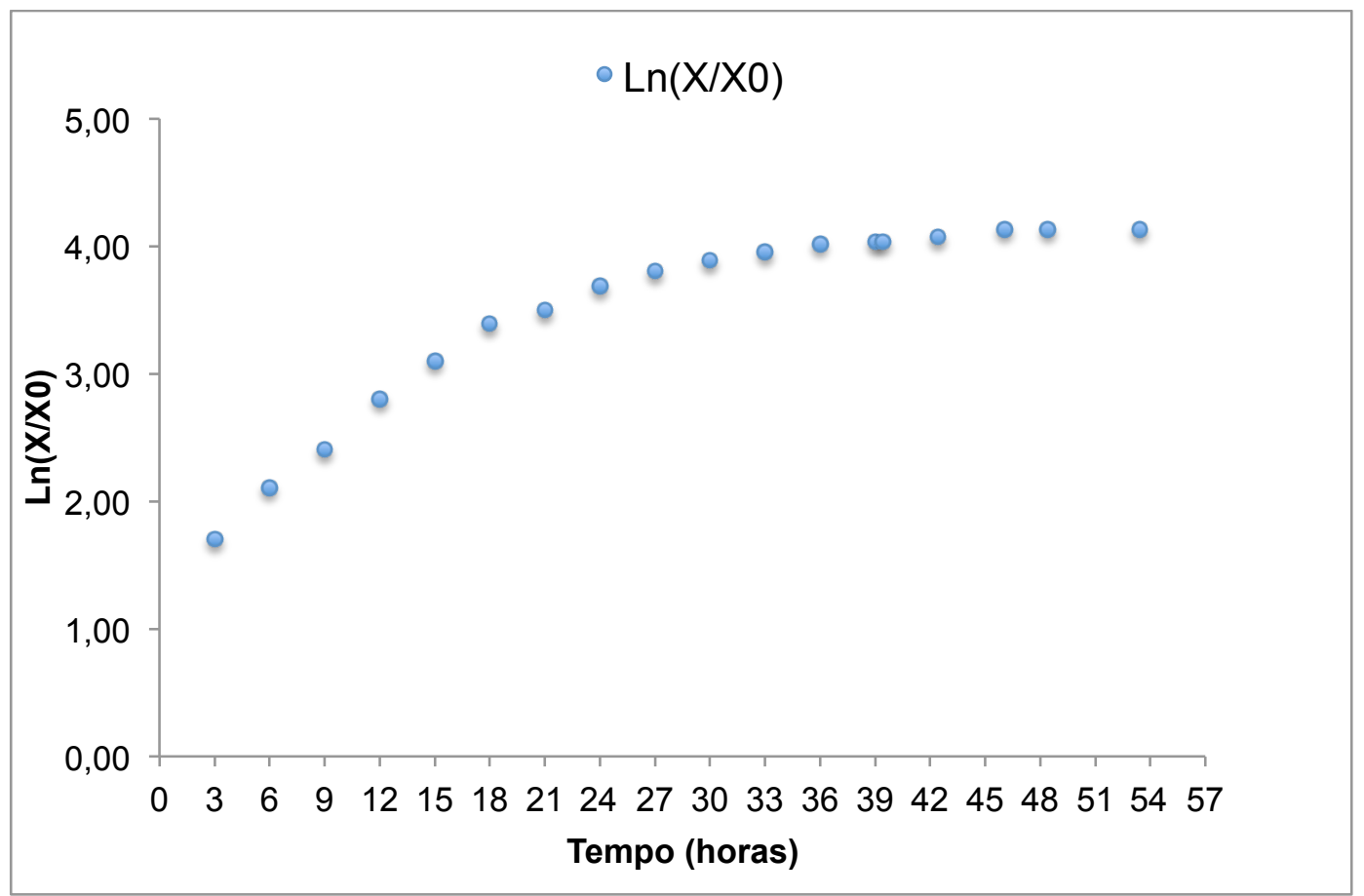

Figura 25 - Regressão linear de $\operatorname{Ln}\left(X / X_{0}\right)$ em função do tempo de cultivo para a Pseudomonas putida sp. no cultivo em batelada alimentada por pulsos - Ensaio FB1

Na regressão linear de $\operatorname{Ln}\left(X / X_{0}\right)$ da Figura 26 determinou-se o valor de $\mu_{\max }$ de $0,11 \mathrm{~h}^{-1}$, ou seja, o mesmo valor obtido no experimento em regime de batelada (item anterior). 


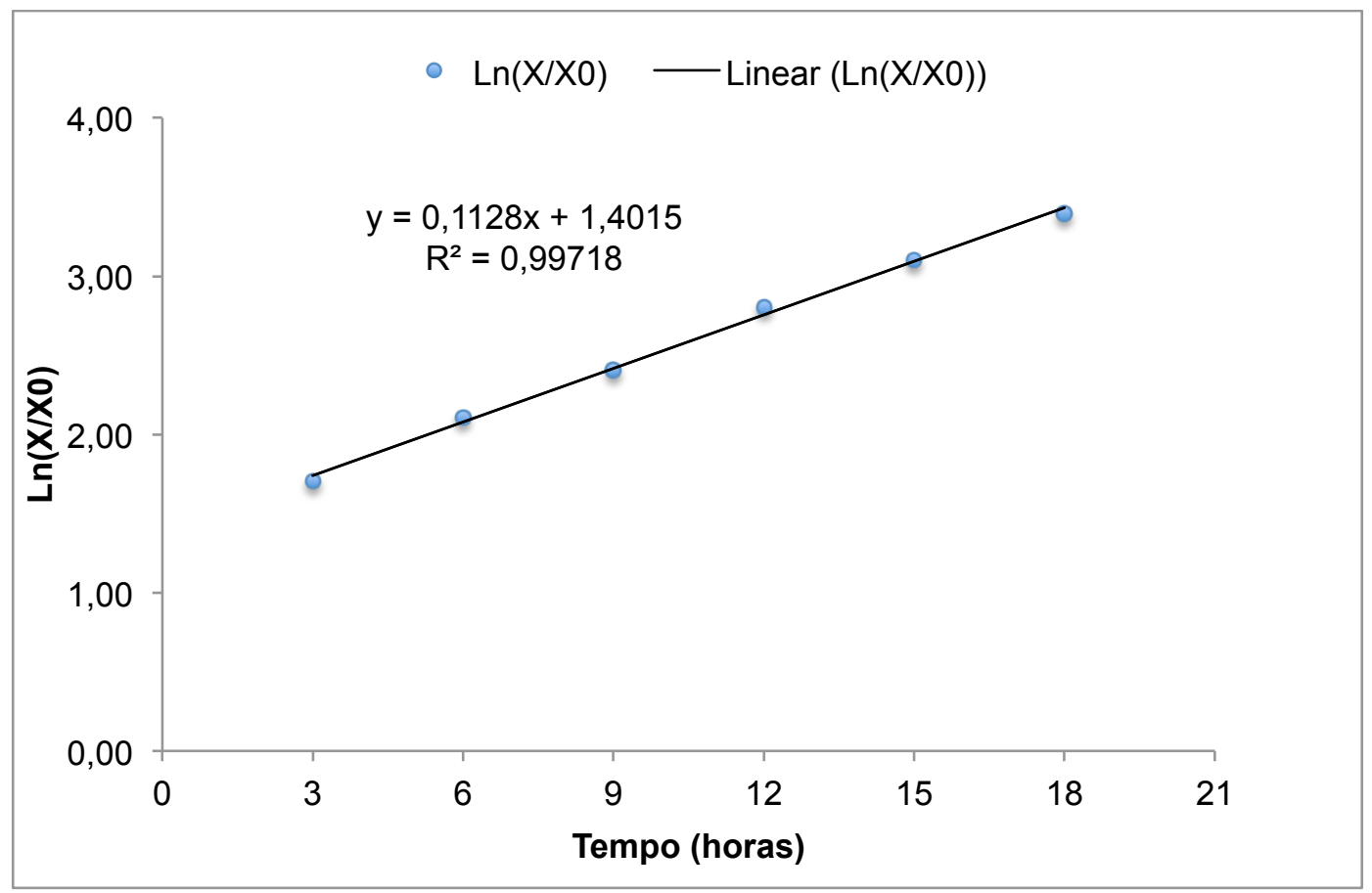

Figura 26 - Regressão linear com a linha de tendência de $\operatorname{Ln}\left(X / X_{0}\right)$ para a Pseudomonas putida sp. no cultivo em batelada alimentada utilizando glicerol - Ensaio FB1

Uma possível explicação para a estabilização do crescimento bacteriano em $13 \mathrm{~g} / \mathrm{L}$ às 46 horas de cultivo com correspondente fator de conversão de glicerol a células, $Y_{x / S}$, de $0,38 \mathrm{~g} / \mathrm{g}$, é a limitação da respiração microbiana pois, não foi possível manter o oxigênio dissolvido na fase líquida, acima de $30 \%$ da saturação de oxigênio em relação ao ar no meio de cultivo, conforme pré-estabelecido. A hipótese de limitação da respiração de oxigênio é reforçada pelo acúmulo de lactato a partir de 24 horas, conforme se apresenta na Figura 27. O lactato é um dos produtos de fermentação possíveis em Pseudomonas putida, pois, esta bactéria é anaeróbia facultativa, ou seja, é capaz de utilizar outros aceptores finais de elétrons do que apenas oxigênio.

Considerando-se os baixos valores de velocidade específica de crescimento, $\mu$, e concentração celular, $\mathrm{X}$, de Pseudomonas putida sp. no cultivo, supôs-se a possibilidade de ineficiência na transferência de oxigênio da fase gasosa para a fase líquida, no reator da Infors. 


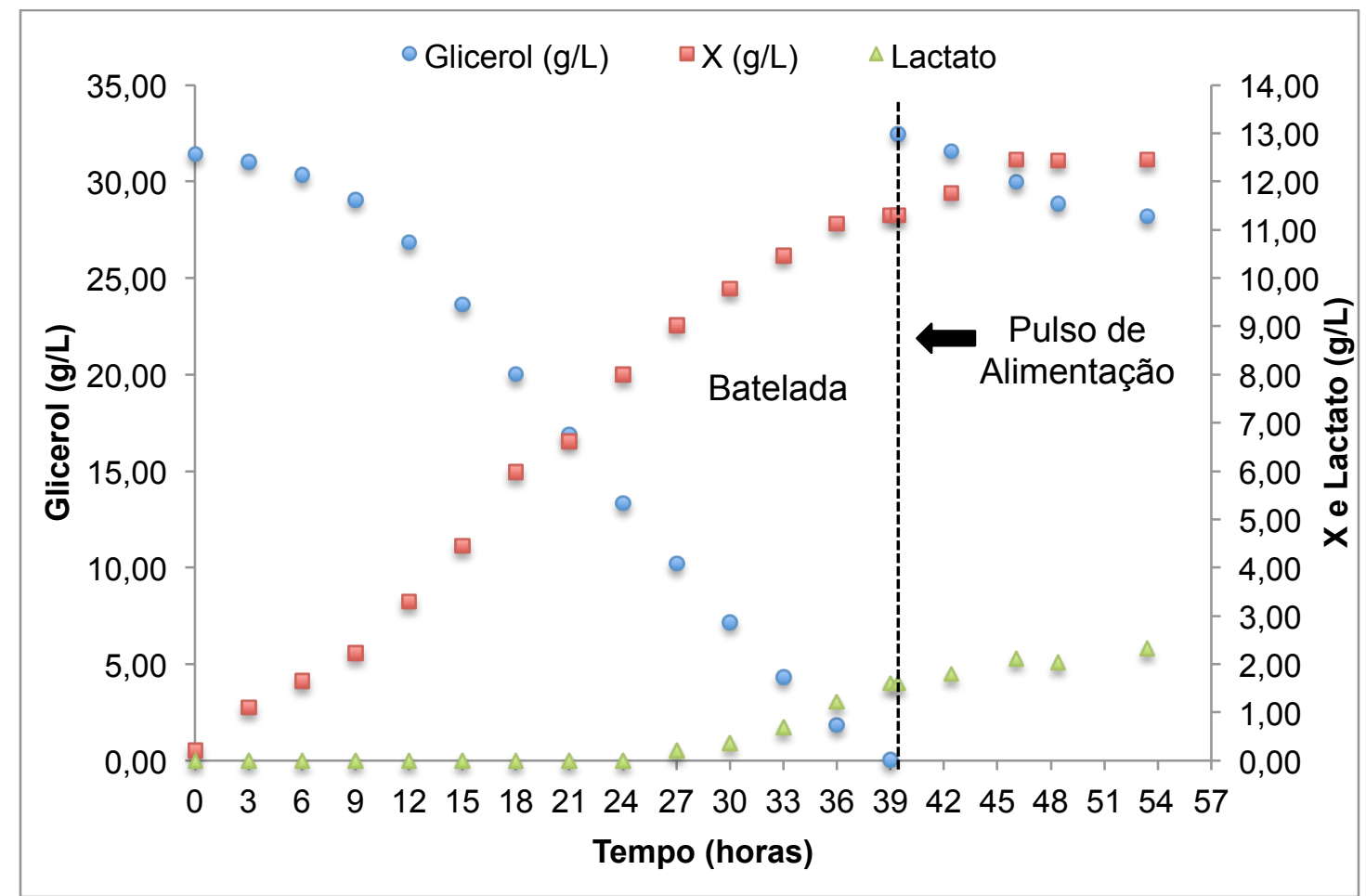

Figura 27 - Concentração de lactato, células e glicerol em função do tempo de cultivo de Pseudomonas putida sp. em meio MM-HCD com glicerol, no cultivo em regime de batelada alimentada por pulsos - Ensaio FB1

\subsubsection{Ensaio FB2}

O Ensaio FB2 foi realizado no reator modelo Labfors 5 (Infors) modificado quanto ao sistema de transferência de oxigênio pela introdução de um aspersor sinterizado e turbina Rushton modificada, modificações essas que resultaram aumento do valor de $\mathrm{k}_{\mathrm{L}} \mathrm{a}$, conforme descrito no Apêndice.

$\mathrm{O}$ cultivo foi realizado com o mesmo meio mineral MM-HCD acrescido de glicerol, pulsos de glicerol e demais nutrientes. A Figura 28 apresenta as curvas de concentração celular e glicerol em função do tempo para a primeira etapa do cultivo em regime de batelada. Pode-se verificar que na nova configuração do reator, o crescimento da bactéria foi mais rápido, pois, $36 \mathrm{~g} / \mathrm{L}$ de glicerol foram consumidos em pouco mais de 24 horas de cultivo, enquanto no ensaio FB1 foram necessárias 39 horas para o consumo de $30 \mathrm{~g} / \mathrm{L}$ de glicerol. 


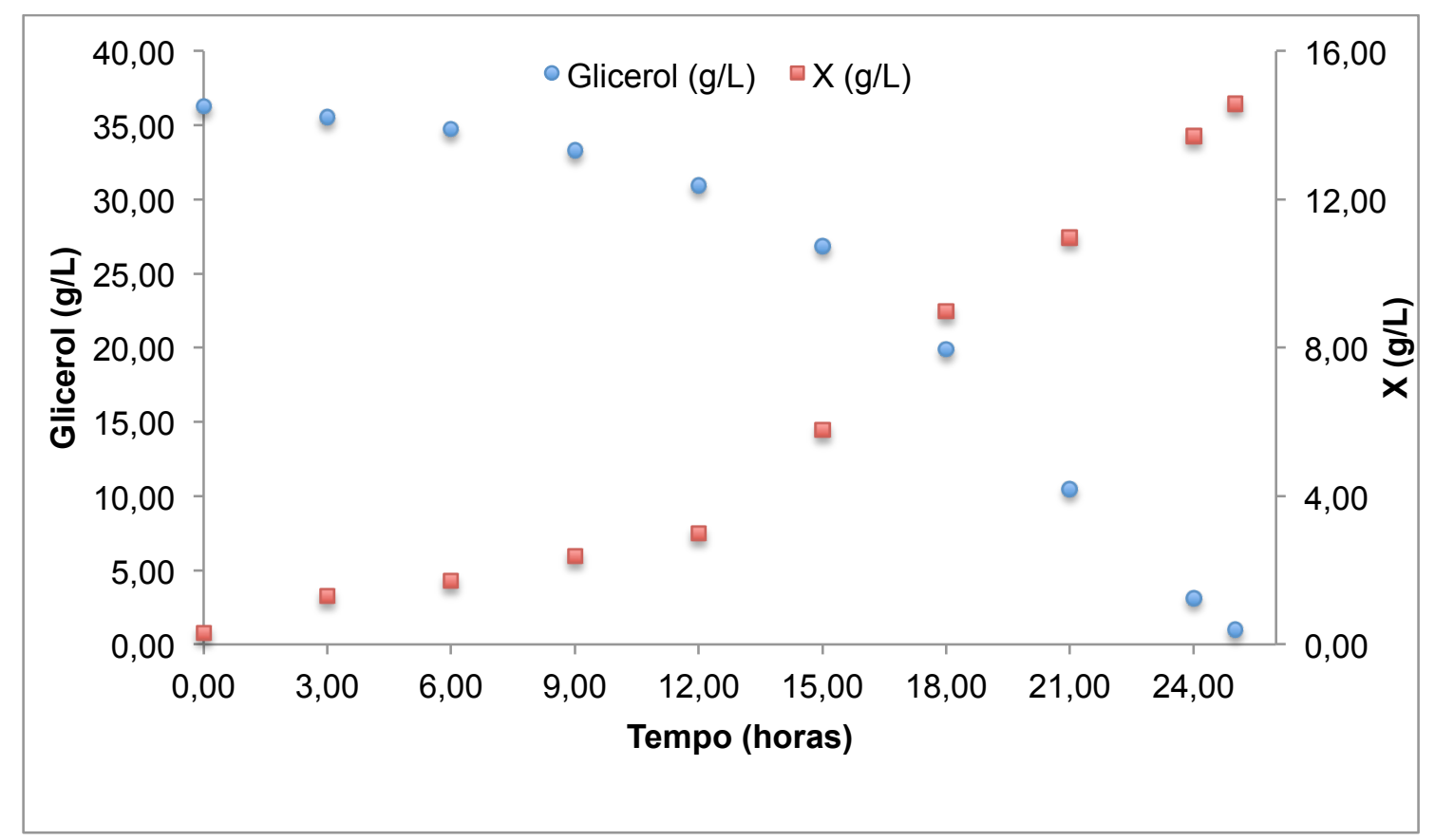

Figura 28 - Concentração de células e glicerol em função do tempo de cultivo de Pseudomonas putida sp. em meio MM-HCD com glicerol, na etapa inicial em regime de batelada simples do Ensaio FB2

Foram realizados 7 pulsos, à medida que a concentração de glicerol era exaurida, cada um contendo 48 gramas de glicerol e quantidade equivalente dos demais nutrientes, resultando na concentração de aproximadamente $30 \mathrm{~g} / \mathrm{L}$ no meio de cultura após cada pulso, conforme se apresenta na Figura 29. A variação da concentração de glicerol no meio após cada pulso é consequência da variação do volume de meio, e esta, por sua vez, é consequência dos pulsos de alimentação e retirada de amostras. O intervalo entre os pulsos diminuiu ao longo do tempo, pois, com o aumento da concentração de células, o tempo para consumo de glicerol diminuiu. 


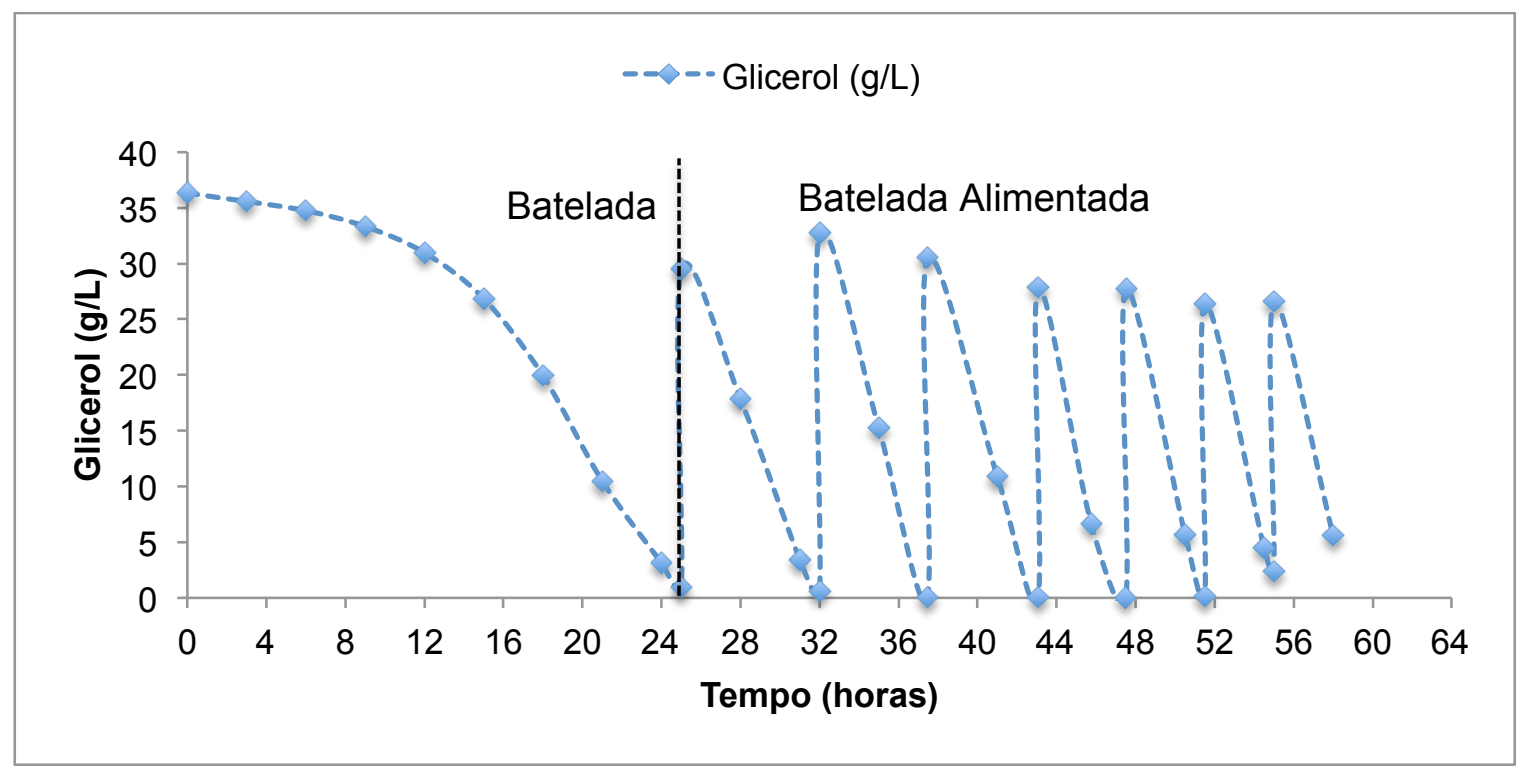

Figura 29 - Concentração de glicerol em função do tempo de cultivo de Pseudomonas putida sp. em meio MM-HCD com glicerol, no regime de batelada alimentada por pulsos - Ensaio FB2

A variação da massa de células, $\mathrm{x}$, em função do tempo de cultivo é apresentada na Figura 30 . Às 58 horas de cultivo e 7 pulsos de alimentação $o$ ensaio foi encerrado tendo-se atingido concentração de células, $X$, de $96 \mathrm{~g} / \mathrm{L}$ e fator de conversão de glicerol a células, $Y_{x / s}$, de $0,42 \mathrm{~g} / \mathrm{g}$.

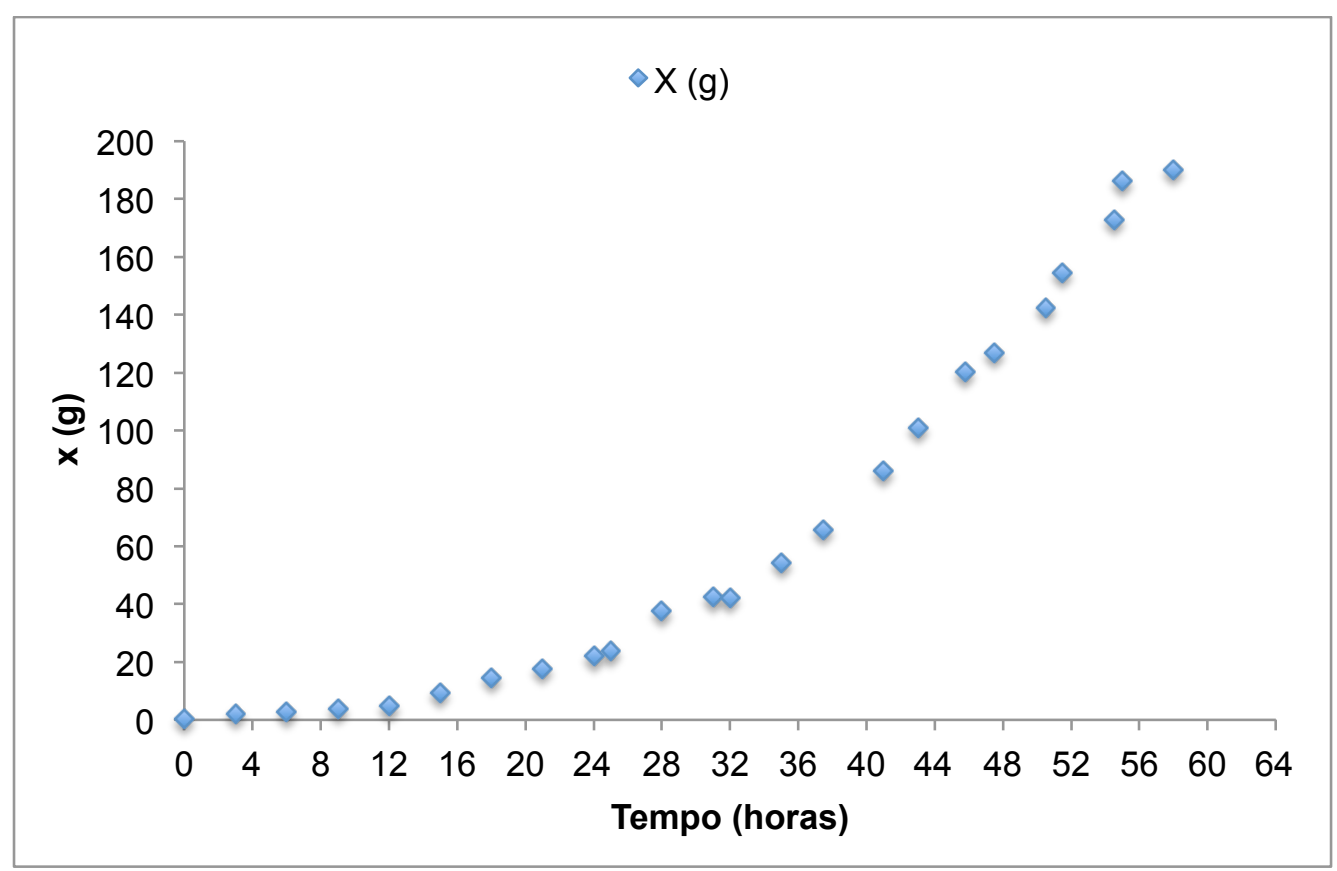

Figura 30 - Massa de células, $x$, em função do tempo de cultivo de Pseudomonas putida sp. em meio MM-HCD com glicerol, regime de batelada alimentada - Ensaio FB2 
Com a nova configuração do reator, isto é, com o aspersor sinterizado e a turbina de Rushton modificada, alta densidade celular foi alcançada, $96 \mathrm{~g} / \mathrm{L}$ de massa seca de células, valor superior àqueles obtidos por diversos autores.

\subsection{Cultivos em Regime de Batelada com Sistema de Filtração e Adição Contínua de Cobre}

\subsubsection{Ensaio BFA1}

Foi realizado cultivo de Pseudomonas putida sp. em meio mineral MM-HCD com concentração inicial de glicerol de $30 \mathrm{~g} / \mathrm{L}$, em regime de batelada, cujos valores de $X$ e concentração de glicerol são apresentados na Figura 31. A exemplo do cultivo anterior, FB2, não houve limitação do crescimento, pois, glicerol foi exaurido em 24 horas e obteve-se $\mu_{\max }$ de $0,11 \mathrm{~h}^{-1}$.

Concluído o cultivo, promoveu-se a filtração da suspensão celular através do sistema de filtração do tipo fibra oca (GE) descrito no item 4.7.3 de Materiais e Métodos. A suspensão celular concentrada foi mantida dentro do reator para a etapa de sorção do cobre continuamente alimentado na forma de uma solução de sulfato de cobre.

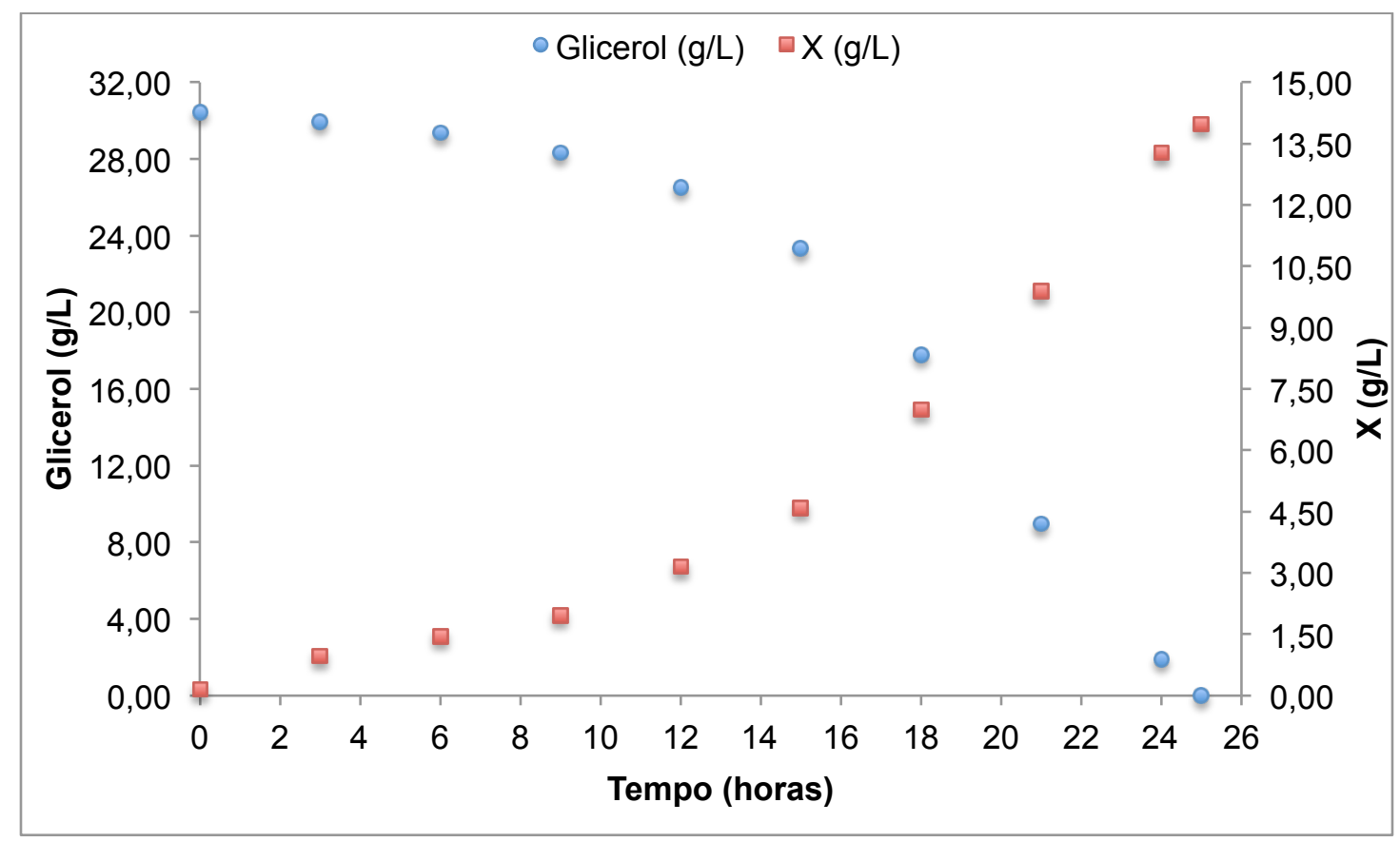

Figura 31 - Concentração de células e glicerol em função do tempo de cultivo de Pseudomonas putida sp. em meio MM-HCD com glicerol, regime de batelada - Ensaio BFA1 
O processo de filtração foi realizado em duas etapas, a saber: na primeira etapa o objetivo foi trocar o meio de cultivo por uma solução tampão de citrato pH 5 e lavar as células, eliminando a possibilidade de influência de metabólitos gerados pela bactéria no processo de sorção de cobre; na segunda etapa o objetivo foi reduzir o volume do meio a fim de aumentar a concentração celular

A primeira etapa de filtração, por sua vez teve também foi realizada por etapas: após 5 horas de funcionamento do sistema de filtração, foi retirado 1,10 $\mathrm{L}$ de permeado (meio livre de bactérias) e foi adicionado ao reator $1,10 \mathrm{~L}$ de solução tampão de citrato em pH 5; após outras 5 horas de filtração, foi retirado 1,10 L de permeado e foi adicionado $0,50 \mathrm{~L}$ de solução tampão de citrato em pH 5 .

A segunda etapa do processo de filtração foi conduzida por 8 horas, até 0 volume do reator ser reduzido a $0,30 \mathrm{~L}$, resultando concentração celular de $54 \mathrm{~g} / \mathrm{L}$. A velocidade de filtração diminuiu à medida que o volume no reator diminuiu, pois o aumento da concentração da celular afetou eficiência do filtro.

Finalmente, ao volume de $0,30 \mathrm{~L}$ de meio tamponado com células foi iniciada a alimentação de solução de sulfato de cobre a 1111 ppm de $\mathrm{Cu}^{2+}$ na vazão de 2,75 $\mathrm{mL} / \mathrm{min}$ em regime contínuo. Com esta vazão de alimentação, em aproximadamente 2 horas o reator foi alimentado com $330 \mathrm{mg}$ de $\mathrm{Cu}^{2+}$ e o volume foi mantido constante em $0,30 \mathrm{~L}$ através do "pescador" do reator.

Após duas horas de alimentação o experimento foi encerrado, pois não foi possível manter o volume no reator, o qual variou de 20 a 30\%. Esta variação se deve ao sistema montado, que envolveu uma bomba para alimentar o sistema de filtração, que por sua vez, realimentava o reator, entretanto, a vazão do reciclo de células para o reator não era constante devido à variação do sistema de filtração utilizado. Além disso, como o reator era alimentado com concentração de cobre aquém da capacidade adsortiva celular para concentração celular presente no reator, o resultado esperado era que na saída do permeado não fosse observado cobre até a saturação das células, entretanto logo no ínicio da alimentação do cobre, já observa-se a coloração azul na saída do permeado, o que indica cobre.

Do processo acima resultou $Q$ de cerca de $1 \mathrm{mg}$ de $\mathrm{Cu}^{2+}$ por grama de célula, valor extremamente baixo se comparado aos valores citados na Revisão Bibliográfica. Uma possível hipótese para esta reduzida sorção é o longo período de filtração, o qual submeteu as células a um elevado estresse, tornando-as inativas para a adsorção. 
O sistema de adsorção contínua utilizado neste experimento não se mostrou adequado, pois, o objetivo era realizar a adsorção de cobre de maneira contínua e que, o permeado (solução livre de células), apresentasse quantidade baixa ou nula de cobre, diferentemente do ocorrido. Os resultados estão descritos na Tabela 17.

Tabela 17 - Resultados de Adsorção - Ensaio BFA1

\begin{tabular}{cccc}
\hline Tempo $(\mathbf{h})$ & $\begin{array}{c}\text { Massa de } \mathrm{Cu}^{2+} \\
\text { adicionada no } \\
\text { reator }(\mathbf{m g})\end{array}$ & $\begin{array}{c}\text { Massa de } \mathrm{Cu}^{2+} \text { na } \\
\text { Saída do Reator } \\
(\mathbf{m g})\end{array}$ & $\begin{array}{c}\text { Percentual de } \\
\text { Cu2+ Removido } \\
\text { do Sistema (\%) }\end{array}$ \\
\hline 2 & 330 & 276 & 16,36 \\
\hline
\end{tabular}

Ao final da etapa de cultivo para crescimento celular, retirou-se uma amostra do reator cujas células foram submetidas a ensaios de adsorção de cobre em diferentes meios: água ultra-pura, tampão citrato $\mathrm{pH} 5$ e meio livre de células (permeado). Foi adicionada a solução de cobre de 1,05 mM (67,3 $\left.\mathrm{mg} \mathrm{de} \mathrm{Cu}^{2+} / \mathrm{L}\right)$ na forma sulfato de cobre em tubos do tipo Falcon contendo concentração celular de $0,75 \mathrm{~g} / \mathrm{L}$, a seguir incubados em estufa rotativa, $180 \mathrm{RPM}$, a $30^{\circ} \mathrm{C}$. Os resultados, Tabela 18, mostram a maior sorção de cobre para as amostras na condição com o meio fermentado, cujo valor de $Q$ foi de aproximadamente de $20 \mathrm{mg} / \mathrm{g}$.

Tabela 18 - Massa de cobre sorvida por massa de células, Q, em função do meio líquido da suspensão de Pseudomonas putida sp.

\begin{tabular}{|c|c|}
\hline Meio de Sorção & $\begin{array}{c}Q \text { (Cu }^{2+} \mathrm{mg} / \mathrm{g} \text { de células } \\
\text { secas })\end{array}$ \\
\hline Água Ultra Pura (pH 6,5) & 0,96 \\
\hline Água Ultra Pura (pH 6,5) & 0,44 \\
\hline Solução Tampão citrato (pH 5) & 3,14 \\
\hline Solução Tampão citrato (pH 5) & 2,05 \\
\hline Permeado (pH 7) & 20,68 \\
\hline Permeado (pH 7) & 21,50 \\
\hline
\end{tabular}

Estes resultados corroboram a hipótese de que o tempo prolongado da filtração pode ter gerado um estresse fisiológico nas células, reduzindo a capacidade de sorção. Outra hipótese é que a lavagem das células com solução tampão de 
citrato em pH 5 também contribuiu com a redução da capacidade de sorção de cobre.

\subsubsection{Ensaio BFA2}

Devido à baixa adsorção de cobre $(Q=1 \mathrm{mg} / \mathrm{g})$ verificada no ensaio BFA1 foi realizado outro experimento em regime de batelada com o meio mineral MM-HCD com concentração inicial de $30 \mathrm{~g} / \mathrm{L}$ de glicerol, no qual a adição de cobre foi realizada por pulsos. Foram realizados alguns ajustes no sistema de filtração como a troca de mangueiras, ajuste de pressão no sistema e processo de retrolavagem a cada 2 horas para melhorar a eficiência do filtro e diminuir o tempo necessário para a filtração reduzindo o estresse celular pelo processo. A concentração celular e o glicerol residual são apresentados na Figura 32 e foi obtido o mesmo valor de $\mu_{\max }$ de $0,11 \mathrm{~h}^{-1}$ dos ensaios FB2, BFA1. Entretanto, o glicerol foi consumido mais rapidamente, com diferença de 3 a 4 horas, e isto pode ser justificado pelo fato que a partir deste experimento, foi utilizada uma concentração inicial de inóculo 2 vezes maior aos ensaios anteriores (FB2 e BFA1).

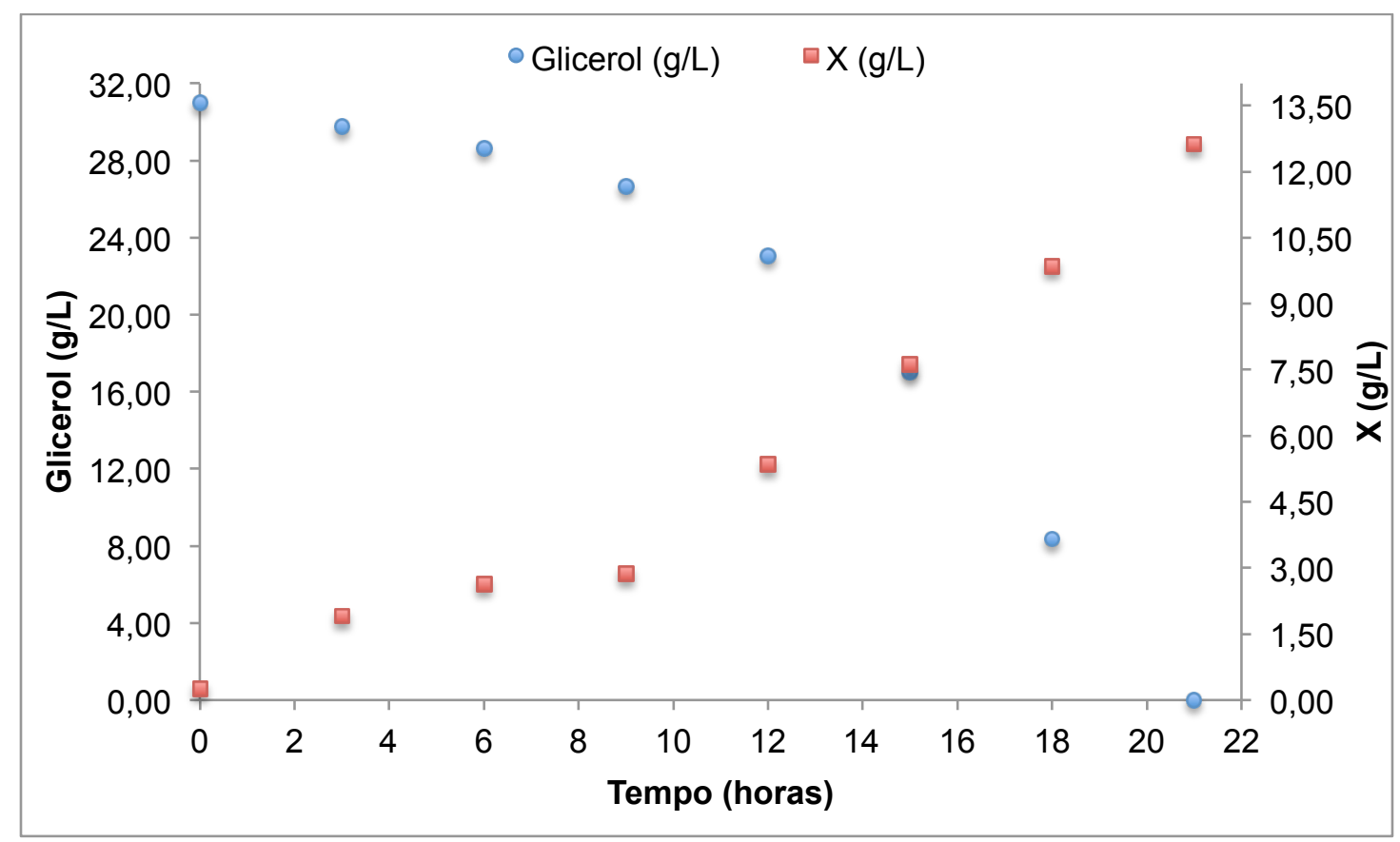

Figura 32 - Concentração de células e glicerol em função do tempo de cultivo de Pseudomonas putida sp. em meio MM-HCD com glicerol, regime de batelada - Ensaio BFA2 
Após a exaustão do glicerol, o sistema de filtração tangencial por meio de fibras ocas da GE foi ligado e, com a melhora na eficiência do sistema de filtração, o volume do reator foi reduzido de $1,60 \mathrm{~L}$ para $0,30 \mathrm{~L}$ em 12 horas e a concentração de células secas obtida foi de $58 \mathrm{~g} / \mathrm{L}$.

No total, foram adicionados 6 pulsos de $2 \mathrm{~mL}$, sendo um pulso a cada 2 horas, de uma solução contendo sulfato de cobre na concentração de 4594 ppm de cobre, ou seja, 9,19 mg de cobre por pulso. Resulta que o aporte específico de cobre foi de $3,23 \mathrm{mg}$ de cobre/g de célula, valor muito aquém da capacidade determinada em 5.4 .3 a qual foi da ordem de $58 \mathrm{mg} / \mathrm{g}$.

A despeito do baixo aporte de cobre face à capacidade de sorção da célula, não foi verificada remoção total do metal do meio, conforme resultados apresentados na Tabela 19. Na falta de melhor explicação para o ocorrido, pode-se cogitar o estresse às células, em resultado às $12 \mathrm{~h}$ de filtração.

Tabela 19 - Massa de cobre sorvida por massa de células, Q, por Pseudomonas putida sp. previamente cultivada em regime de batelada e submetida a filtração tangencial - Ensaio BFA2

\begin{tabular}{cccc}
\hline $\begin{array}{c}\text { Número de } \\
\text { Pulsos }\end{array}$ & $\begin{array}{c}\text { Tempo após a adição } \\
\text { da solução de } \\
\mathrm{Cu}_{2} \mathbf{S O}_{4 \cdot 7 \mathrm{H}_{2} \mathbf{O}(\mathrm{h})}\end{array}$ & $\begin{array}{c}\mathbf{Q}\left(\mathrm{Cu}^{2+} \mathbf{m g} / \mathbf{g}\right. \\
\text { de células } \\
\text { secas) }\end{array}$ & $\begin{array}{c}\text { Percentual de } \mathrm{Cu}^{2+} \\
\text { Removido (\%) }\end{array}$ \\
\hline 1 & 2 & 0,14 & 91,1 \\
2 & 4 & 0,29 & 90,5 \\
3 & 6 & 0,43 & 90,2 \\
4 & 8 & 0,58 & 91,6 \\
5 & 10 & 0,72 & 90,3 \\
6 & 12 & 0,87 & 91,9 \\
\hline
\end{tabular}

Deve-se ressaltar que estes resultados levantam uma questão a ser avaliada, que é o motivo pelo qual uma grande quantidade de células na presença de uma baixa concentração de cobre não é capaz de remover todo o cobre do sistema. 


\subsection{Cultivos de Pseudomonas putida sp. em Regime de Batelada e Sorção de Cobre em Diferentes Estágios do Crescimento - Ensaios BA1 e BA2}

Avaliou-se a influência do estado fisiológico de Pseudomonas putida sp. na sorção de cobre, em dois cultivos realizados em regime de batelada simples e meio mineral MM acrescido de glicerol na concentração de 5,0 g/L: no ensaio BA1 cobre foi adicionado uma única vez ao final da fase logarítmica do crescimento, instante no qual todo glicerol havia sido consumido; no ensaio BA2, cobre também foi adicionado uma única vez, porém, na metade da fase logarítmica do crescimento (Figuras 33 e 34).

A concentração de solução de sulfato de cobre adicionada no ensaio BA1 foi de $74,16 \mathrm{mg} / \mathrm{L}$ ou $1,17 \mathrm{mM}$ de $\mathrm{Cu}^{2+}$ e no ensaio BA2 foi $76,54 \mathrm{mg} / \mathrm{L}$ ou $1,20 \mathrm{mM}$ de $\mathrm{Cu}^{2+}$, portanto, praticamente a mesma nos dois ensaios. Foram utilizadas as concentrações de $\mathrm{Cu}^{2+}$ entre 1,17 mM e 1,20 mM, pois este valor seria equivalente a um dos valores utilizados nos ensaios de determinação da isoterma de Langmuir.

Verifica-se na Figura 34 que o crescimento bacteriano no ensaio BA2 foi temporariamente limitado a partir do instante da adição do cobre, o que sugere inibição parcial do crescimento pelo cobre, pois, glicerol continuou sendo consumido. Os fatores de conversão de glicerol a células $\left(Y_{x / s}\right)$ nos ensaios 1 e 2 que foram respectivamente, 0,53 e 0,43 g/g. O valor menor de $Y_{x / s}$ para o ensaio 2 pode sugerir a hipótese que a célula utilizou o glicerol para produzir energia para o processo de bioacumulação de cobre, o qual necessita de energia conforme descrito por Gravilescu (2004), Lemos et al. (2008) e Volesky (2007). 


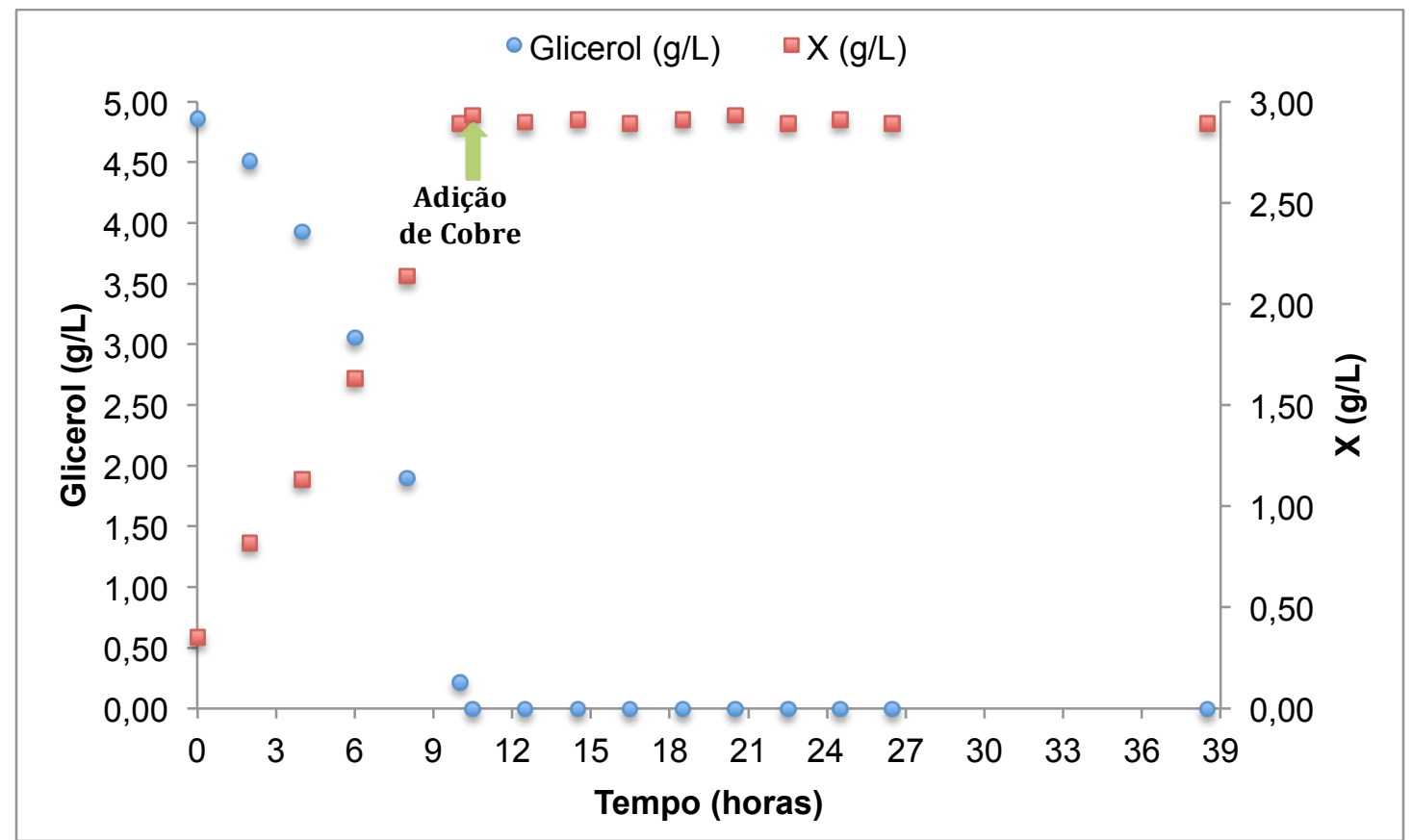

Figura 33 - Concentração de células e glicerol em função do tempo de cultivo de Pseudomonas putida sp. em meio MM, regime de batelada simples, com adição de solução de sulfato de cobre, $74,16 \mathrm{mg} / \mathrm{L}$ de $\mathrm{Cu}^{2+}$, ao final da fase logarítmica - Ensaio BA1

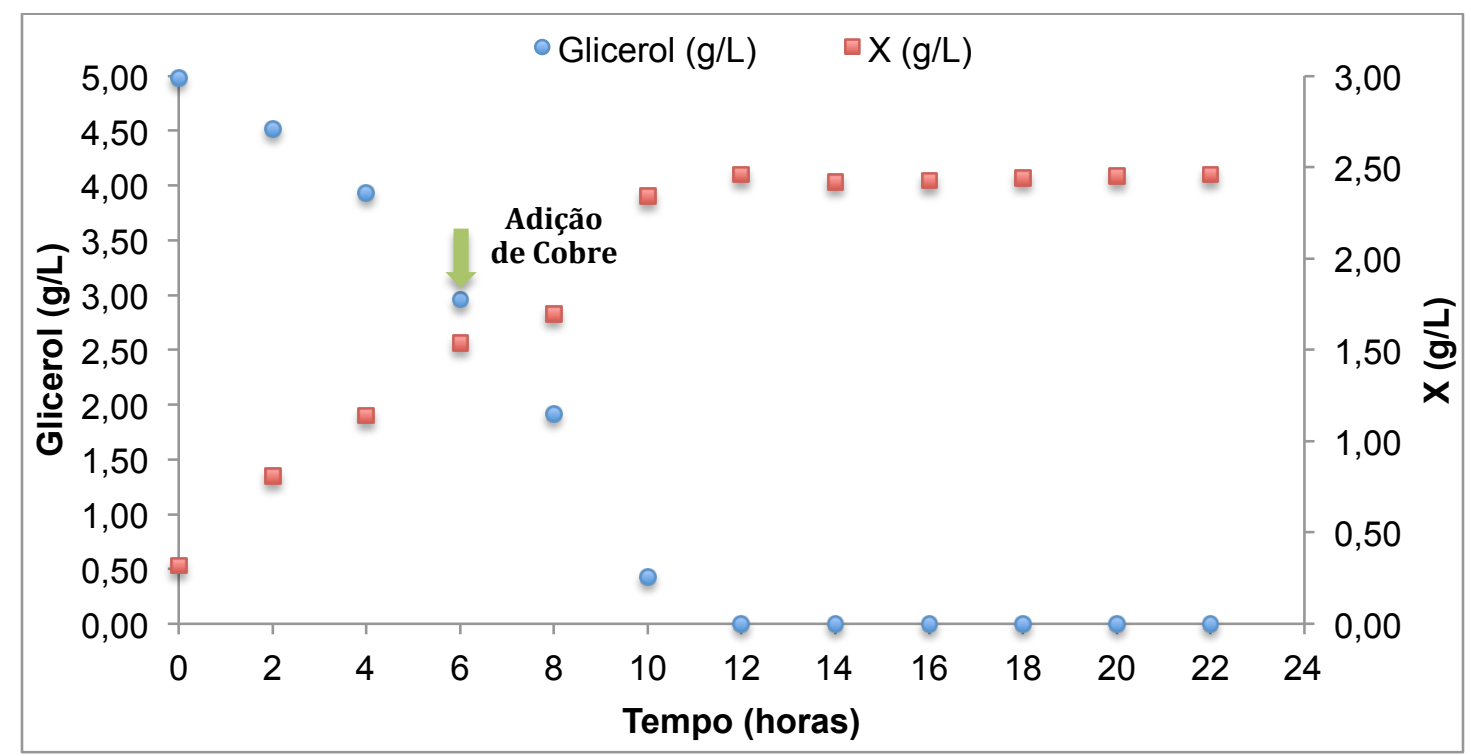

Figura 34 - Concentração de células e glicerol em função do tempo de cultivo de Pseudomonas putida sp. em meio MM, regime de batelada simples, com adição de solução de sulfato de cobre, $76,54 \mathrm{mg} / \mathrm{L}$ de $\mathrm{Cu}^{2+}$, na metade da fase logarítimica - Ensaio BA2

Os resultados de $Q$ para os ensaios BA1 e BA2 encontram-se nas Tabelas 20 e 21, respectivamente. Os resultados de adsorção de cobre para o ensaio BA1 praticamente não sofreram alteração para os intervalos de contato da célula com o 
cobre e foram da ordem de $21 \mathrm{mg}$ de $\mathrm{Cu}^{2+}$ por grama de células secas. Já os resultados de sorção de cobre para o ensaio BA2 sofreram diminuição com o tempo até o intervalo de 4 horas na presença de cobre devido à continuação do crescimento bacteriano, pois este crescimento foi proporcionalmente maior que a sorção de cobre, até que o glicerol fosse completamente exaurido. Depois deste intervalo, os valores de sorção estabilizaram-se na faixa de $26 \mathrm{mg}$ de cobre por grama de células secas, entretanto, o maior valor de sorção de cobre para o ensaio BA2 foi da ordem de $36 \mathrm{mg}$ de cobre por grama de células secas para o intervalo de 2 horas de incubação.

Tabela 20 - Resultados de Sorção de Cobre para Pseudomonas putida sp. em crescimento em meio mineral, regime de batelada simples, adição de solução de sulfato de cobre, $74,16 \mathrm{mg} / \mathrm{L}$ de $\mathrm{Cu}^{2+}$, ao final da fase logarítmica - Ensaio BA1

\begin{tabular}{ccc}
\hline $\begin{array}{c}\text { Tempo após a adição da } \\
\text { solução CuSO }\end{array} \mathbf{A H}_{\mathbf{2}} \mathbf{O} \mathbf{~ ( h )}$ & $\begin{array}{c}\mathbf{Q}\left(\mathbf{m g ~ d e ~ C u}^{2+} \mathbf{g} \text { de }\right. \\
\text { células secas) }\end{array}$ & $\mathbf{X}(\mathbf{g} / \mathbf{L})$ \\
\hline 2,0 & 21,0 & 2,90 \\
4,0 & 20,9 & 2,91 \\
6,0 & 20,9 & 2,89 \\
8,0 & 21,0 & 2,91 \\
10,0 & 21,0 & 2,93 \\
12,0 & 20,9 & 2,89 \\
14,0 & 21,0 & 2,91 \\
16,0 & 21,3 & 2,89 \\
26,5 & 21,2 & 2,89 \\
\hline
\end{tabular}


Tabela 21 - Resultados de Sorção de Cobre para Pseudomonas putida sp. em crescimento em meio mineral, regime de batelada simples, com única adição de solução de sulfato de cobre, $76,54 \mathrm{mg} / \mathrm{L}$ de $\mathrm{Cu}^{2+}$, na metade da fase logarítmica - Ensaio BA2

\begin{tabular}{|c|c|c|c|}
\hline $\begin{array}{c}\text { Tempo de Cultivo } \\
\text { (h) }\end{array}$ & $\begin{array}{c}\text { Tempo após a adição } \\
\text { da solução } \mathrm{CuSO}_{4.7 \mathrm{H}_{2} \mathrm{O}} \\
\text { (h) }\end{array}$ & $\begin{array}{c}Q\left(\mathrm{mg} \text { de } \mathrm{Cu}^{2+} / \mathrm{g} \text { de }\right. \\
\text { células secas) }\end{array}$ & $X(g / L)$ \\
\hline 8 & 2 & 36,7 & 1,70 \\
\hline 10 & 4 & 26,8 & 2,34 \\
\hline 12 & 6 & 26,0 & 2,46 \\
\hline 14 & 8 & 26,6 & 2,42 \\
\hline 16 & 10 & 26,6 & 2,43 \\
\hline 18 & 12 & 26,5 & 2,44 \\
\hline 20 & 14 & 26,4 & 2,45 \\
\hline 22 & 16 & 26,2 & 2,46 \\
\hline
\end{tabular}

Com os resultados dos ensaios BA1 e BA2, pode-se sugerir que a sorção de cobre é maior quando este é adicionado fase logarítmica e a adição de cobre na presença de glicerol sugere a hipótese da ocorrência da bioacumulação de cobre, que requer metabolismo catabólico, conforme mencionado anteriormente.

\subsection{Cultivos de Pseudomonas putida sp. em Regime de Batelada Alimentada sob Vazão Exponencial, seguidos de Sorção de Cobre}

\subsubsection{Ensaio 1}

Este ensaio foi realizado com o objetivo de promover a sorção de cobre em células de Pseudomonas putida sp. crescendo sob valor máximo da velocidade específica de crescimento, isto é, $\mu_{\max }$, tendo em vista os resultados apresentados no ensaio $B A 1$, segundo os quais houve maior sorção no ensaio $B A 2, Q$ da ordem de $26 \mathrm{mg} / \mathrm{g}$, em comparação ao ensaio $B A 1, Q$ da ordem de $21 \mathrm{mg} / \mathrm{g}$, resultados que podem ser atribuídos ao estado fisiológico das células.

O ensaio 1 foi alimentado com vazão exponencialmente crescente da solução de nutrientes, segundo uma função sob valor de $\mu$ da ordem de grandeza de $\mu_{\max }$ definida em Material e Métodos (4.10), considerando-se os valores $Y_{X / S}=0,45 \mathrm{~g} / \mathrm{g}, \mu$ $=0,11 \mathrm{~h}^{-1}, \mathrm{~S}_{0}=700 \mathrm{~g} / \mathrm{L}$ (glicerol), $\mathrm{V}_{0}=1,60 \mathrm{~L}$ e $\mathrm{m}_{\mathrm{s}}=0 \mathrm{~g} / \mathrm{g} \cdot \mathrm{h}$. 
Para manter o crescimento celular sob valor de $\mu$ da ordem de grandeza de $\mu_{\max }$, foi escolhida a faixa de valores de concentração de glicerol de 12 a $14 \mathrm{~g} / \mathrm{L}$, o que representa a concentração de glicerol na metade da fase logarítmica de de crescimento conforme definido no ensaio FB2.

O cultivo foi iniciado em regime de batelada com $30 \mathrm{~g} / \mathrm{L}$ de glicerol e concentração equivalente dos demais nutrientes conforme o meio mineral MM-HCD definido em Materiais e Metódos, a alimentação foi iniciada às 18 horas do cultivo. A Figura 35 apresenta a curva da massa celular e glicerol residual. $O$ crescimento atingiu valor de $52 \mathrm{~g}$ em um volume final no reator de 1,47 L, portanto, uma concentração celular, $X$, de $35,4 \mathrm{~g} / \mathrm{L}$. Devido a uma falha no microcontrolador modelo Arduino Uno que comanda a bomba de alimentação, a faixa de valores de concentração de glicerol desejada (12 a $14 \mathrm{~g} / \mathrm{L}$ ) não foi mantida. Além disso, não foi possível determinar a concentração de glicerol após 22 horas de cultivo, pois o equipamento de HPLC apresentou excesso de pressão e, sem os dados de concentração de glicerol, não foi possível corrigir a falha do microprocessador microcontrolador modelo Arduino Uno.

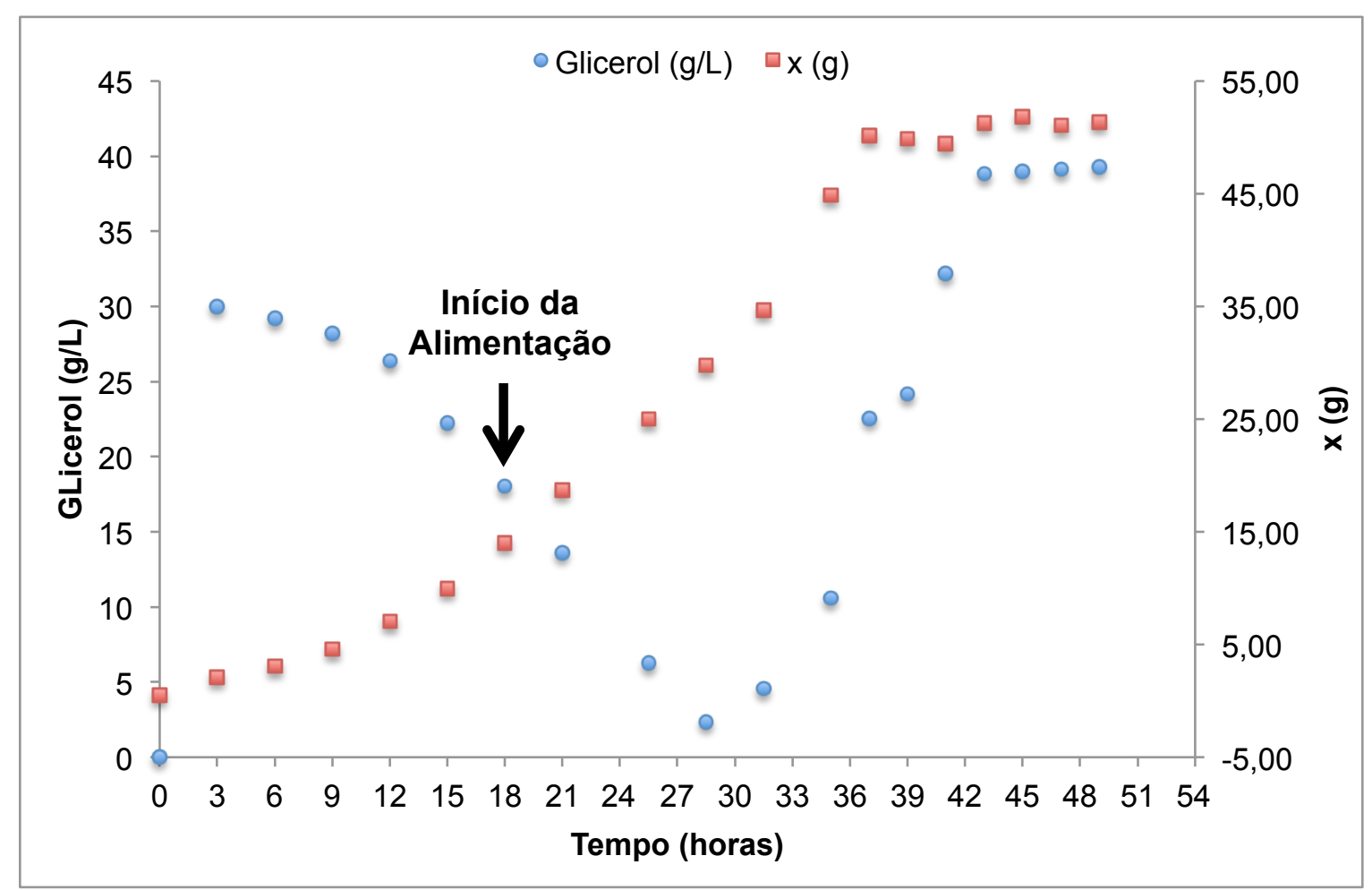

Figura 35 - Ensaio 1: Massa de células, $x$, e glicerol em função do tempo de cultivo de Pseudomonas putida sp. em regime de batelada alimentada sob vazão exponencial seguido de sorção de cobre 
Devido à falha do microcontrolador modelo Arduino Uno em conjunto com a ausência da determinação do glicerol durante o ensaio a partir de 22 horas de cultivo, foi utilizado o monitoramento do percentual da fração molar de $\mathrm{CO}_{2}$ da saída do reator para controlar a alimentação. A bomba de alimentação foi mantida ligada e quando os valores de percentual de fração molar de $\mathrm{CO}_{2}$, que são apresentados na Figura 36, começavam a diminuir, a vazão de alimentação da bomba era aumentada.

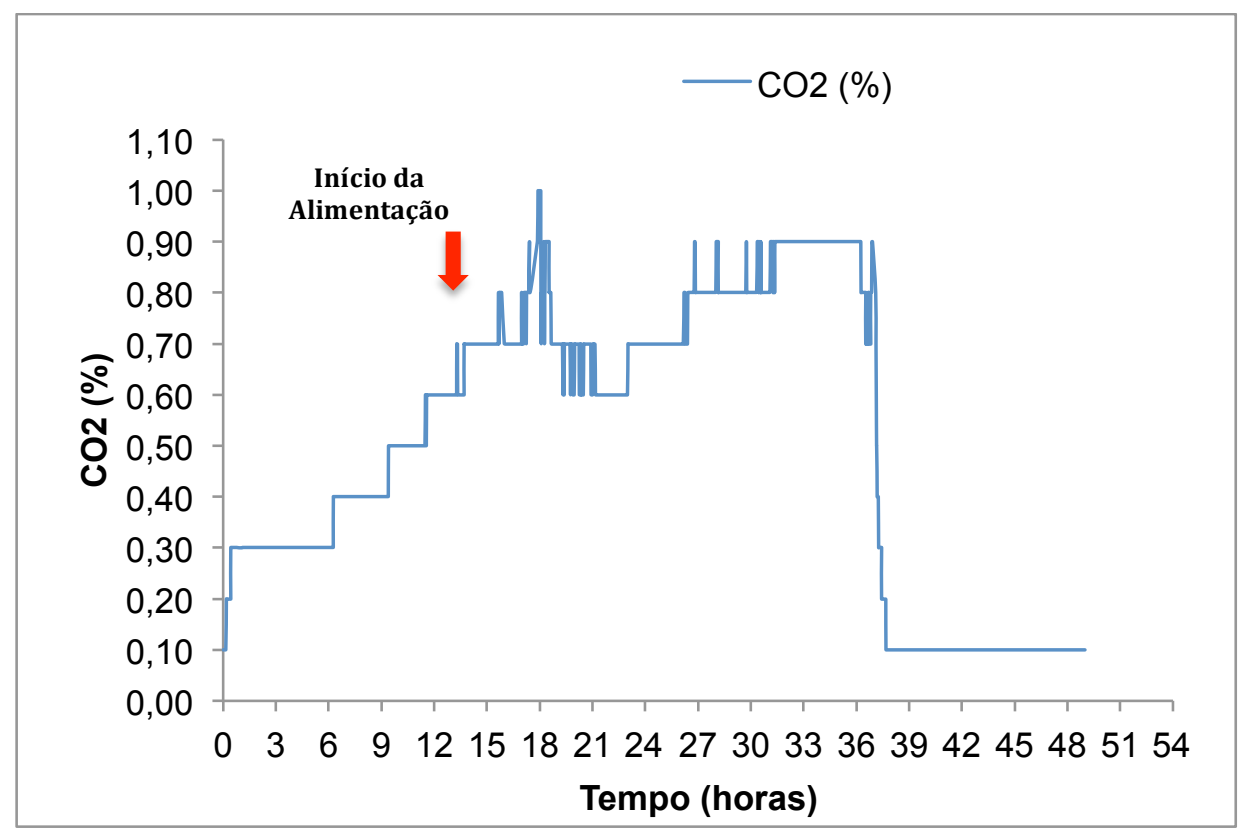

Figura 36 - Ensaio 1: Percentual de $\mathrm{CO}_{2}$ no gás de saída do reator em função do tempo de cultivo de Pseudomonas putida sp. em regime de batelada alimentada sob vazão exponencial seguido de sorção de cobre

Foi possível manter o crescimento sob valor de $\mu_{\max }$ de $0,11 \mathrm{~h}^{-1}$ por 28,5 horas de cultivos. Nas Figuras 37 e 38 pode-se verificar, respectivamente, a regressão linear de $\operatorname{Ln}\left(X / X_{0}\right)$ em função do tempo para todo o cultivo e a linha de tendência para o intervalo entre 3 e 28,5 horas, no qual o valor de $\mu$ foi máximo. 


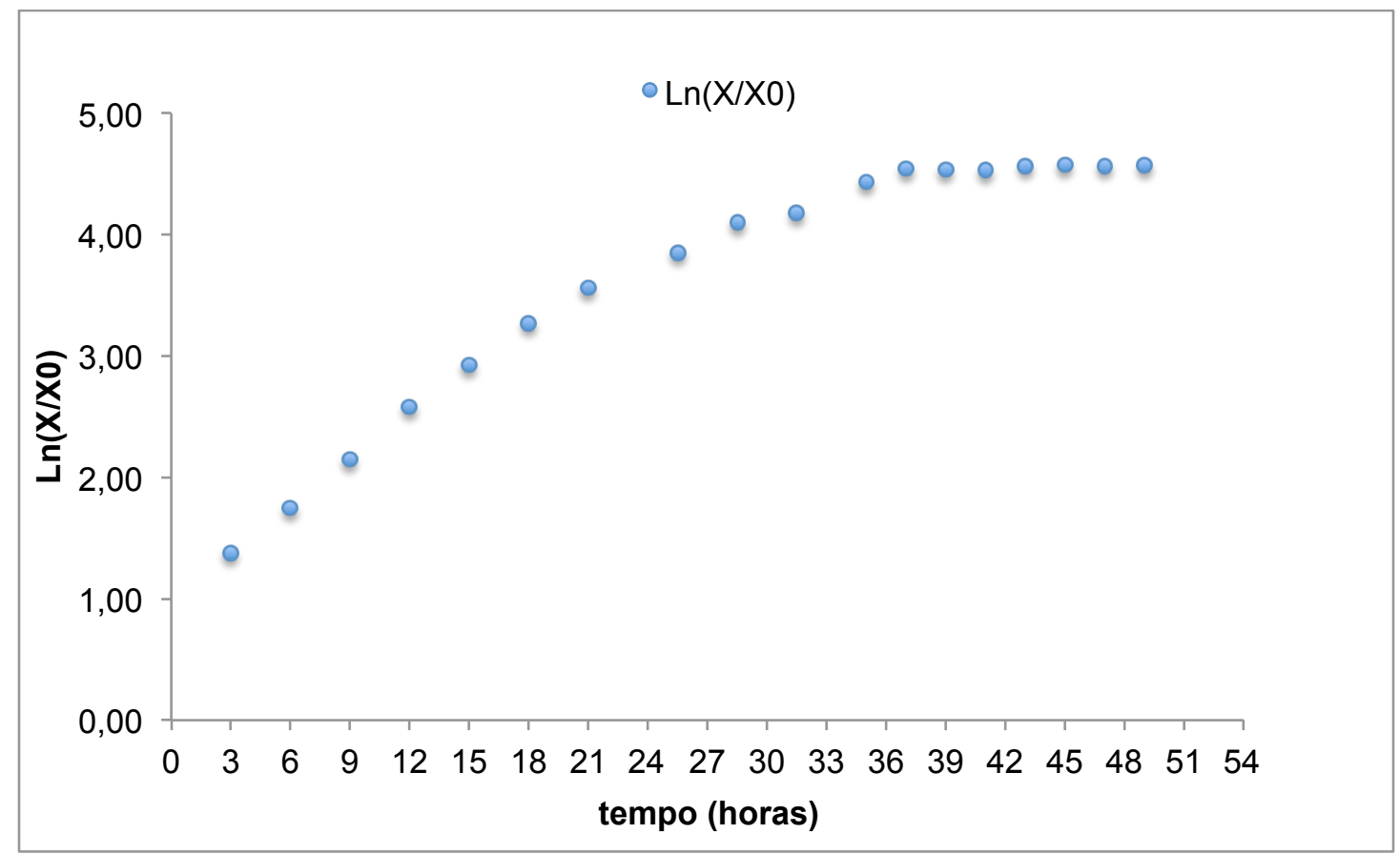

Figura 37 - Ensaio 1: Regressão linear de $\operatorname{Ln}\left(X / X_{0}\right)$ em função do tempo de cultivo de Pseudomonas putida sp. em regime de batelada alimentada sob vazão exponencial seguido de sorção de cobre

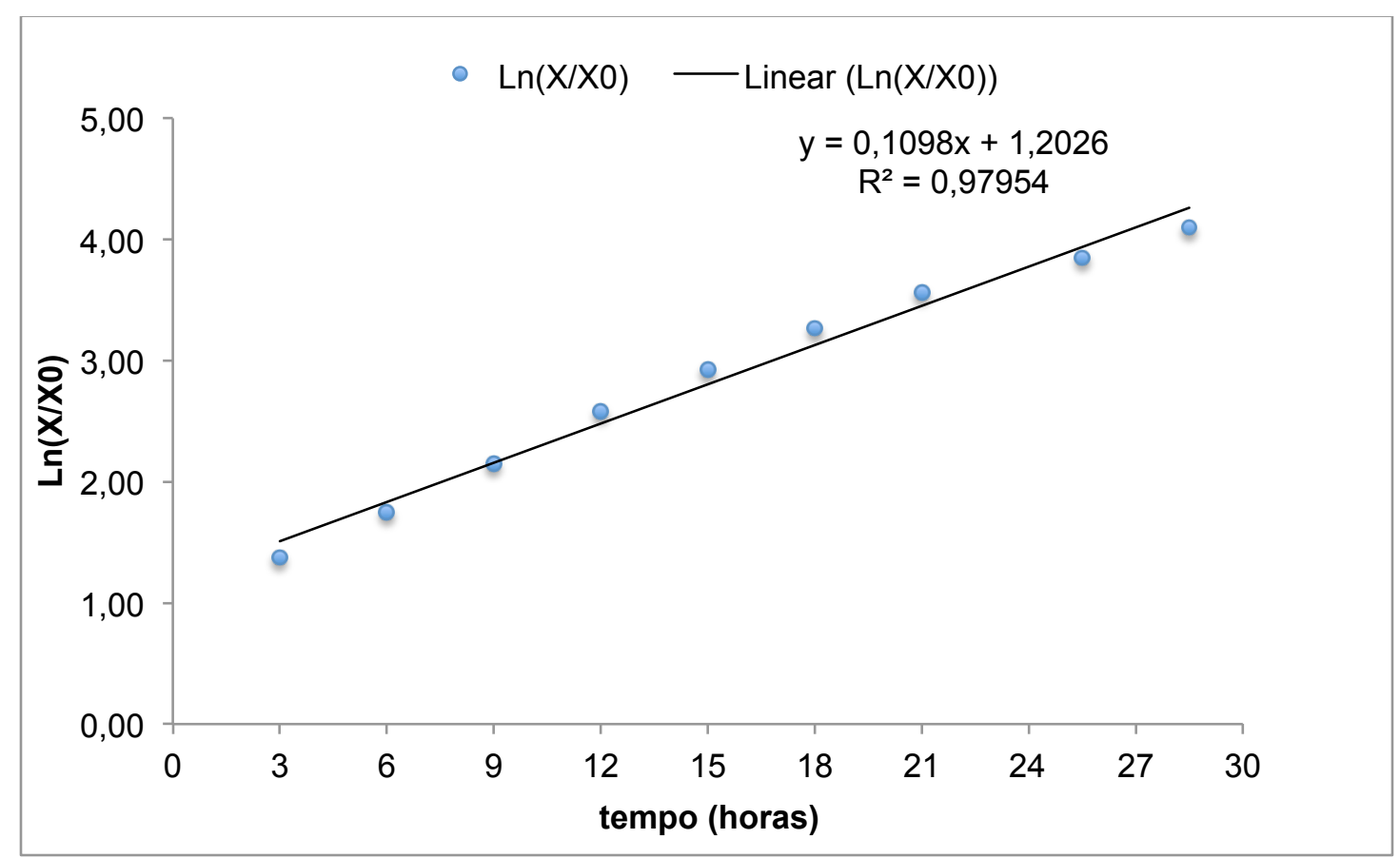

Figura 38 - Ensaio 1: Regressão linear com a linha de tendência de $\operatorname{Ln}\left(X / X_{0}\right)$ no cultivo com alimentação exponencial de glicerol e nutrientes para o intervalo de $3-28,5$ horas no ensaio de Pseudomonas putida sp. em regime de batelada alimentada sob vazão exponencial seguido de sorção de cobre 
No intervalo entre 32 e 36 horas, não foi verificado aumento nos valores percentuais de $\mathrm{CO}_{2}$, que é uma possível indição da redução da velocidade de crescimento. Portanto, em 37 horas de cultivo, optou-se por adicionar único pulso da solução de sulfato de cobre, totalizando $1037 \mathrm{mg}$ de cobre ou 10,25 mM (652 ppm) no reator. Pode-se verificar que imediatamente após a adição do cobre, houve inibição do crescimento das células, pois os valores percentuais de $\mathrm{CO}_{2}$ sofreram redução de 0,9 para 0,1, o valor da massa seca de células manteve-se constante.

Os valores de $\mathrm{Q}$ foram da ordem de $15 \mathrm{mg} \mathrm{de} \mathrm{Cu}^{2+} / \mathrm{grama}$ de células secas, como pode ser verificado na Tabela 22.

Tabela 22 - Valores de $Q(\mathrm{mg} / \mathrm{g})$ no cultivo do Ensaio 1 com alimentação exponencial de glicerol e nutrientes

\begin{tabular}{cccc}
\hline $\begin{array}{c}\text { Tempo de } \\
\text { Cultivo (h) }\end{array}$ & $\begin{array}{c}\text { Tempo após a adição da } \\
\text { solução de CuSO } \mathbf{~}_{\mathbf{4} \cdot \mathbf{7}} \mathbf{O} \mathbf{O}(\mathbf{h})\end{array}$ & $\begin{array}{c}\mathbf{Q}\left(\mathbf{m g ~ d e ~} \mathrm{Cu}^{2+} / \mathbf{g} \text { de }\right. \\
\text { células secas) }\end{array}$ & $\mathbf{X}(\mathbf{g} / \mathbf{L})$ \\
\hline 39 & 2 & 15,59 & 49,93 \\
41 & 4 & 15,64 & 49,45 \\
43 & 6 & 14,73 & 51,26 \\
45 & 8 & 16,59 & 51,79 \\
47 & 10 & 14,54 & 51,11 \\
49 & 12 & 15,89 & 51,38 \\
\hline
\end{tabular}

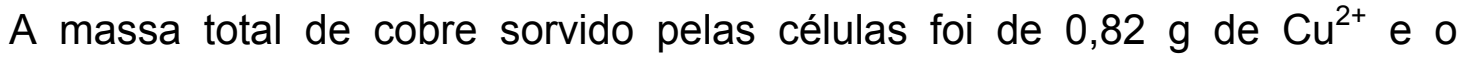
percentual total de cobre sorvido foi de $79 \%$.

\subsubsection{Ensaio 2}

Neste segundo cultivo para sorção de cobre por células crescendo sob valor máximo de $\mu, \mu_{\max }$, em regime de batelada alimentada, o programa de alimentação do microcontrolador modelo Arduino Uno foi alterado para o controle de vazão de alimentação pela bomba.

$\mathrm{O}$ cultivo foi iniciado com $30 \mathrm{~g} / \mathrm{L}$ de glicerol no meio mineral MM-HCD, portanto, semelhante ao experimento apresentado no item 5.9.1. A alimentação também foi iniciada as 18 horas de cultivo, o que corresponde à metade da fase logarítmica do crescimento conforme foi verificado nos ensaio do capítulo anterior. 
As curvas de massa celular e glicerol residual estão apresentadas na Figura 39. Este cultivo resultou em $60 \mathrm{~g}$ de massa seca de células em um volume final de $1,45 \mathrm{~L}$, portanto, uma concentração de células secas de $41,4 \mathrm{~g} / \mathrm{L}$, a qual é maior em relação ao experimento anterior, no qual a concentração celular final foi de foi atingida $35,4 \mathrm{~g} / \mathrm{L}$. Devido ao excesso de alimentação dos nutrientes realizado pelo erro no programa de alimentação do microcontrolador modelo Arduino Uno, o qual não permitiu controlar a vazão da bomba de acordo com a função determinada, o valor de $\mu_{\max }$ foi mantido em $0,11 \mathrm{~h}^{-1}$ até o tempo de cultivo de 33 horas.

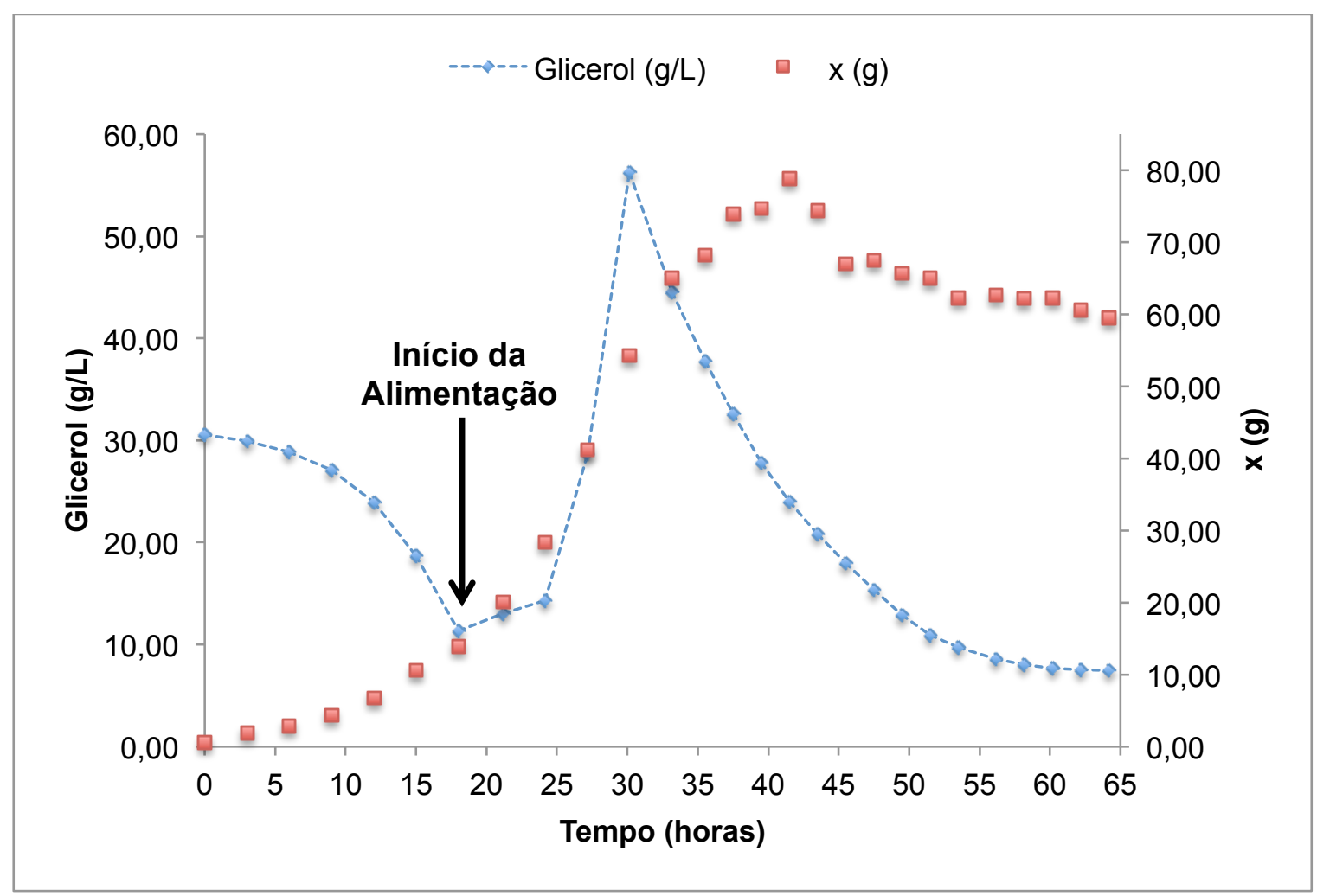

Figura 39 - Ensaio 2: Massa de células, x, e glicerol em função do tempo de cultivo de Pseudomonas putida sp. em regime de batelada alimentada sob vazão exponencial seguido de sorção de cobre

Nas Figuras 40 e 41 são apresentadas, respectivamente, a regressão linear de $\operatorname{Ln}\left(X / X_{0}\right)$ em função do tempo para todo o cultivo e a regressão linear de $\operatorname{Ln}\left(X / X_{0}\right)$ com a linha de tendência para o intervalo de 3 até 33 horas, no qual o valor de $\mu$ foi máximo. 


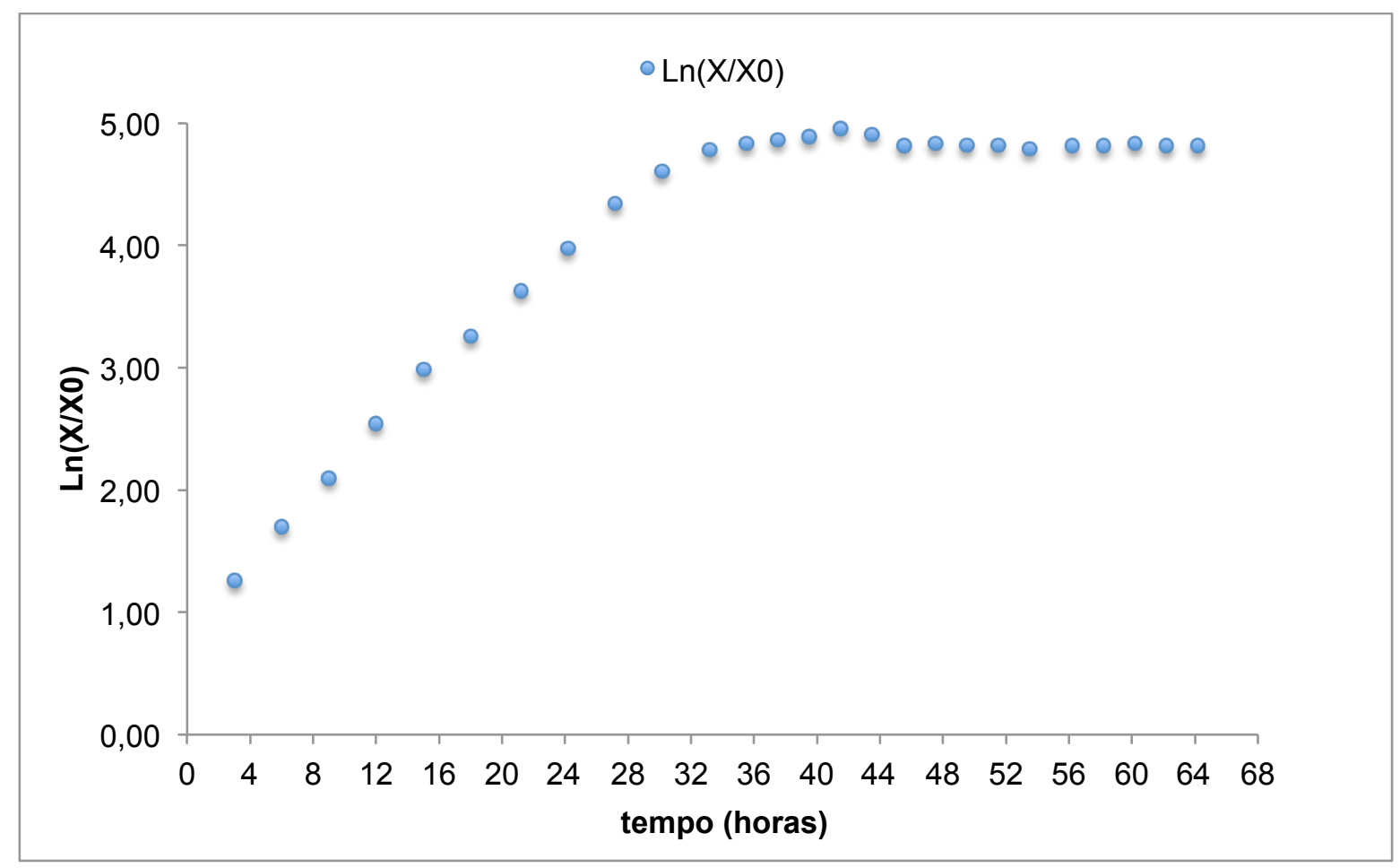

Figura 40 - Ensaio 2: Regressão linear de $\operatorname{Ln}\left(X / X_{0}\right)$ em função do tempo de cultivo de Pseudomonas putida sp. em regime de batelada alimentada sob vazão exponencial seguido de sorção de cobre

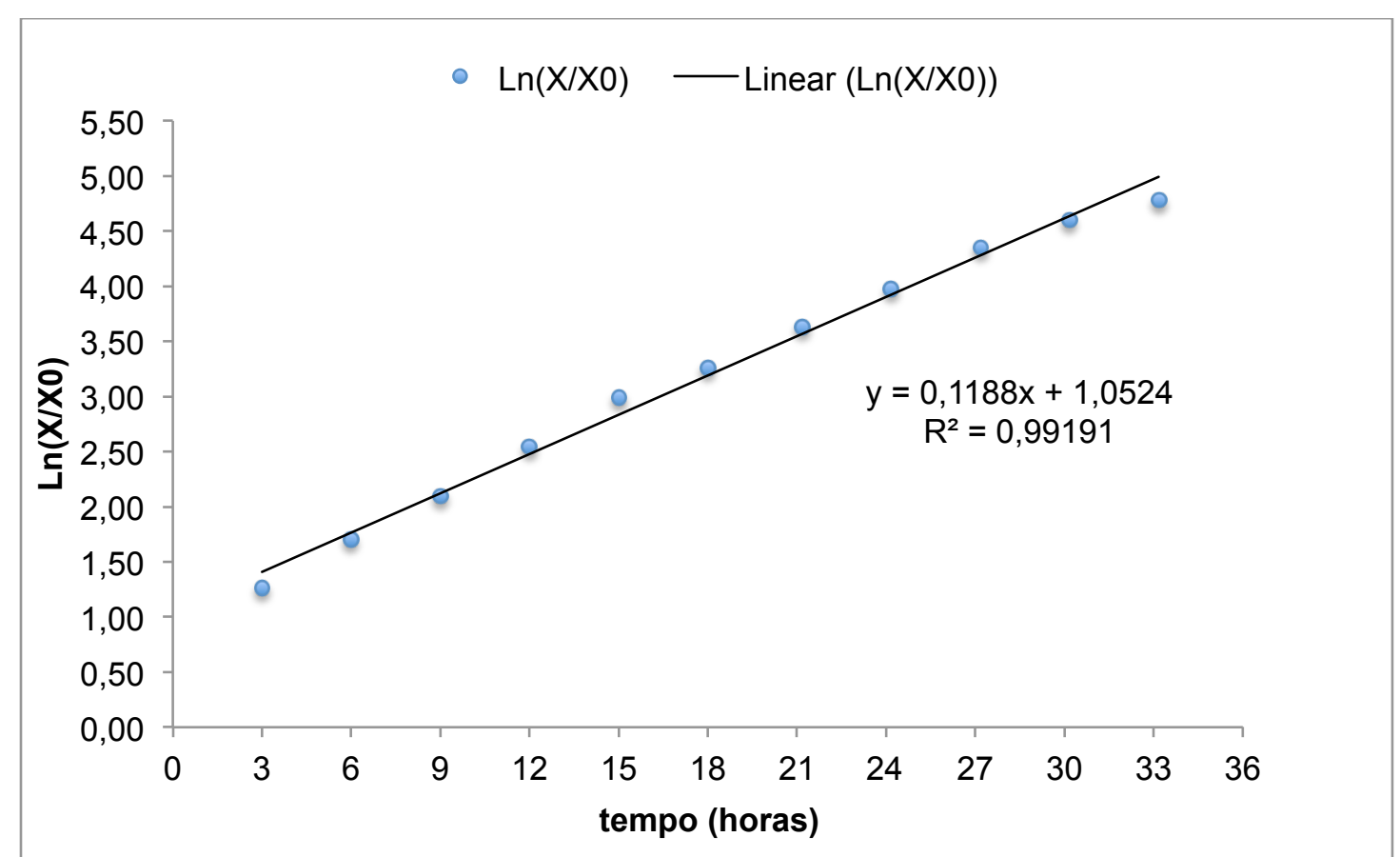

Figura 41 - Ensaio 2: Regressão linear com a linha de tendência de $\operatorname{Ln}\left(X / X_{0}\right)$ no cultivo com alimentação exponencial de glicerol e nutrientes para o intervalo de $3-33,5$ horas no ensaio de Pseudomonas putida sp. em regime de batelada alimentada sob vazão exponencial seguido de sorção de cobre 
Com diminuição do valor de $\mu$ a partir de 35,5 horas de cultivo, foi iniciada a adição de pulsos, a cada 2 horas, de $143 \mathrm{mg}$ de cobre na forma de solução de sulfato de cobre. Foram realizados 14 pulsos de cobre, totalizando a adição de 2002 mg de $\mathrm{Cu}^{2+}$ no reator. A Tabela 23 apresenta as concentrações de cobre acumulado no reator logo após cada pulso.

Tabela 23 - Ensaio 2: Concentração de $\mathrm{Cu}^{2+}$ acumulada logo após cada pulso

\begin{tabular}{ccc}
\hline $\begin{array}{c}\text { Número de } \\
\text { Pulsos }\end{array}$ & $\begin{array}{c}\text { Concentração de } \mathbf{C u}^{2+} \\
\text { acumulada no Reator } \\
(\mathbf{m g} / \mathbf{L})\end{array}$ & $\begin{array}{c}\text { Concentração de } \mathbf{C u}^{2+} \\
\text { acumulada no Reator } \\
(\mathbf{m M})\end{array}$ \\
\hline 1 & 83,60 & 1,31 \\
2 & 169,17 & 2,66 \\
3 & 256,80 & 4,04 \\
4 & 346,54 & 5,45 \\
5 & 438,49 & 6,89 \\
6 & 532,73 & 8,38 \\
7 & 629,34 & 9,90 \\
8 & 728,40 & 11,45 \\
9 & 830,03 & 13,05 \\
10 & 934,31 & 14,69 \\
11 & 1041,35 & 16,37 \\
12 & 1151,27 & 18,10 \\
13 & 1264,18 & 19,88 \\
14 & 1380,20 & 21,70 \\
\hline
\end{tabular}

O crescimento bacteriano ocorreu até 41,5 horas de cultivo, instante após o quinto pulso de cobre, possivelmente pela inibição do cobre acumulado como apresentando na Figura 42 (massa de células em função do tempo). 


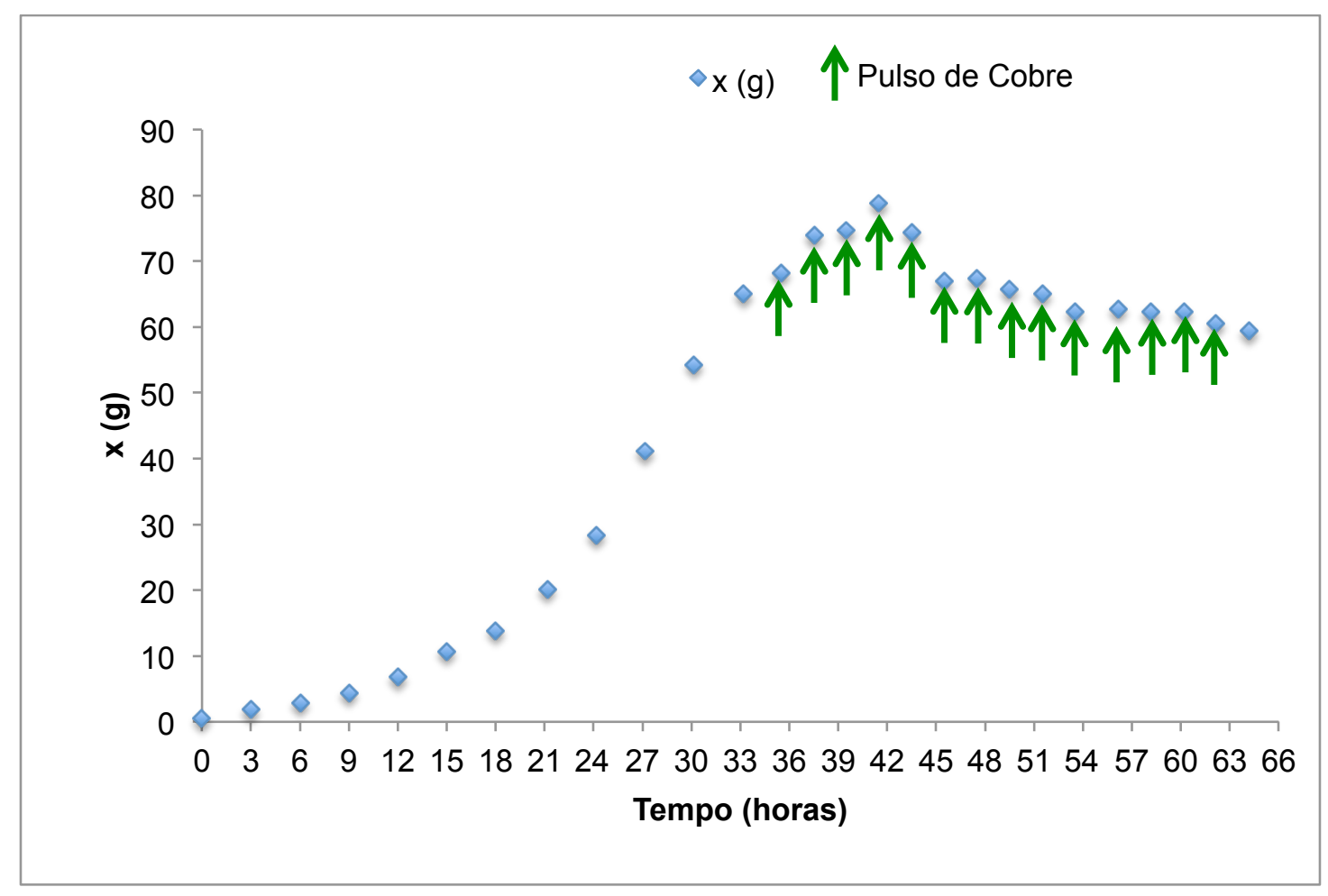

Figura 42 - Ensaio 2: Massa de células, x, em função do tempo de cultivo de Pseudomonas putida sp. em regime de batelada alimentada sob vazão exponencial seguido de sorção de cobre

Os valores de adsorção de cobre foram crescentes com a adição dos pulsos do metal, como apresentado na Tabela 24. O maior valor obtido foi da ordem de 29 $\mathrm{mg}$ de $\mathrm{Cu}^{2+} / \mathrm{grama}$ de células secas. A hipótese para a diminuição da concentração celular após o quarto pulso, mesmo com glicerol e nutrientes disponíveis e $\mathrm{pO}_{2}$ acima de $30 \%$, é de que a adição de cobre pode resultar na lise celular causada pela concentração de cobre acumulada no reator. 
Tabela 24 - Adsorção de Cobre no Ensaio 2

\begin{tabular}{ccccc}
\hline $\begin{array}{c}\text { Número de } \\
\text { Pulsos }\end{array}$ & $\begin{array}{c}\text { Tempo de } \\
\text { Cultivo (h) }\end{array}$ & $\begin{array}{c}\text { Tempo após a adição da } \\
\text { solução de CuSO } \\
\text { (h) } \mathbf{7} \mathrm{H}_{\mathbf{2}} \mathbf{O}\end{array}$ & $\begin{array}{c}\mathbf{Q}\left(\mathbf{m g ~ d e ~} \mathrm{Cu}^{2+} \mathbf{g}\right. \\
\text { de células secas) }\end{array}$ & $\mathbf{X}(\mathbf{g} / \mathbf{L})$ \\
\hline 1 & 37,50 & 2,00 & 1,11 & 43,20 \\
2 & 39,50 & 4,00 & 2,46 & 44,20 \\
3 & 41,50 & 6,00 & 3,84 & 47,20 \\
4 & 43,50 & 8,00 & 5,25 & 45,10 \\
5 & 45,50 & 10,00 & 7,39 & 41,10 \\
6 & 47,50 & 12,00 & 9,29 & 41,90 \\
7 & 49,50 & 14,00 & 11,09 & 41,30 \\
8 & 51,50 & 16,00 & 13,17 & 41,40 \\
9 & 53,50 & 18,00 & 16,22 & 40,20 \\
10 & 55,17 & 20,67 & 19,33 & 41,00 \\
11 & 58,17 & 22,67 & 21,22 & 41,20 \\
12 & 60,17 & 24,67 & 23,28 & 41,80 \\
13 & 62,17 & 26,67 & 26,25 & 41,20 \\
14 & 64,17 & 28,67 & 29,02 & 41,00 \\
\hline
\end{tabular}

A adição do cobre por pulsos mostrou-se uma opção mais vantajosa para sorção de cobre, pois a massa total de cobre sorvido neste ensaio foi de $1,72 \mathrm{~g}$ de $\mathrm{Cu}^{2+}$ e o percentual total de cobre sorvido foi de $86 \%$, portanto foi obtida uma adsorção de cobre quase duas vezes maior que aquela obtida no ensaio anterior (5.9.1), no qual o cobre foi adicionado em um único pulso de $1037 \mathrm{mg} \mathrm{de} \mathrm{Cu}^{2+}$ $(10,25 \mathrm{mM})$.

Deve-se salientar que embora o crescimento celular tenha cessado em 41,5 horas de cultivo, 16,53 $\mathrm{g} / \mathrm{L}$ de glicerol foram consumidos no intervalo entre 41,5 e 64,17 horas. Este consumo pode indicar que o glicerol está sendo utilizado para produzir energia necessária para a bioacumulação (GRAVILESCU, 2004; LEMOS et al., 2008; VOLESKY, 2007). 


\subsubsection{Ensaio 3}

Neste terceiro cultivo para sorção de cobre por células crescendo sob valor máximo de $\mu, \mu_{\max }$, em regime de batelada alimentada, o microcontrolador modelo Arduino Uno foi substituído por um novo, devido aos problemas ocorridos nos cultivos anteriores (5.9.1 e 5.9.2), no controle de vazão de alimentação pela bomba.

O cultivo foi iniciado com $30 \mathrm{~g} / \mathrm{L}$ de glicerol no meio mineral MM-HCD, portanto, semelhante aos experimentos anteriores. No instante imediatamente antes do início da alimentação, 18 horas, o microcontrolador modelo Arduino Uno apresentou uma falha de comunicação com a bomba e não foi possível utilizá-lo, portanto optou-se por realizar pulsos de maneira manual com concentrações variáveis de glicerol e nutrientes.

As curvas de massa celular e glicerol residual durante o cultivo estão apresentadas na Figura 43. Este cultivo resultou em 79,50 g de massa seca de células em um volume final de 1,80 L, ou seja, concentração celular de 44,20 g/L.

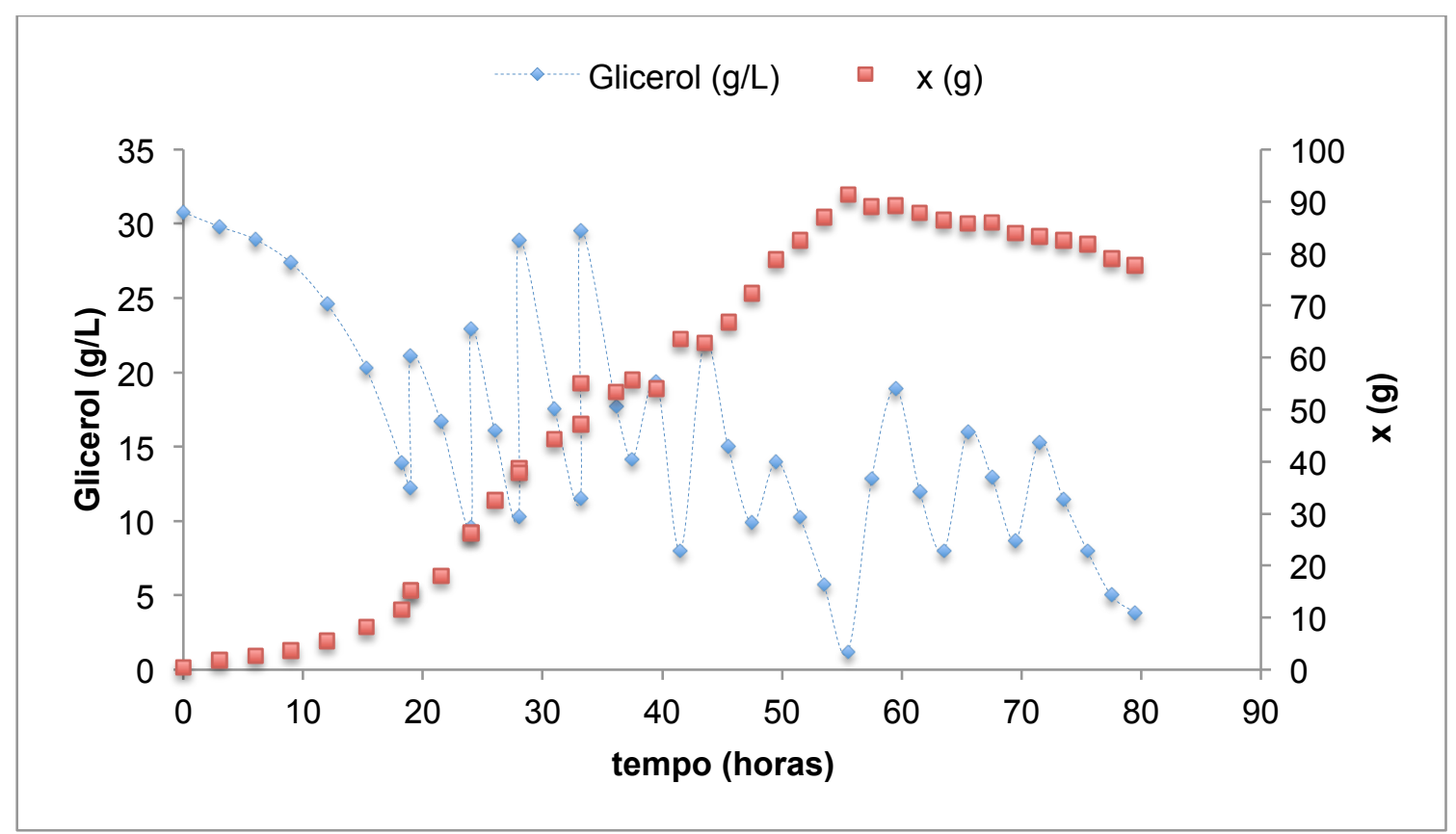

Figura 43 - Ensaio 3: Massa de células, x, e glicerol em função do tempo de cultivo de Pseudomonas putida sp. em regime de batelada alimentada sob vazão exponencial seguido de sorção de cobre

Utilizando alimentação através de pulsos manuais, foi possível manter o valor de $\mu$, em $\mu_{\max }$ por até 36 horas de cultivo. 
Nas Figuras 44 e 45 verifica-se, respectivamente, a regressão linear de $\operatorname{Ln}\left(X / X_{0}\right)$ em função do tempo para todo o cultivo e a regressão linear de $\operatorname{Ln}\left(X / X_{0}\right)$ com a linha de tendência para o intervalo de 3 até 36 horas, respectivamente, no qual o valor de $\mu$ foi máximo.

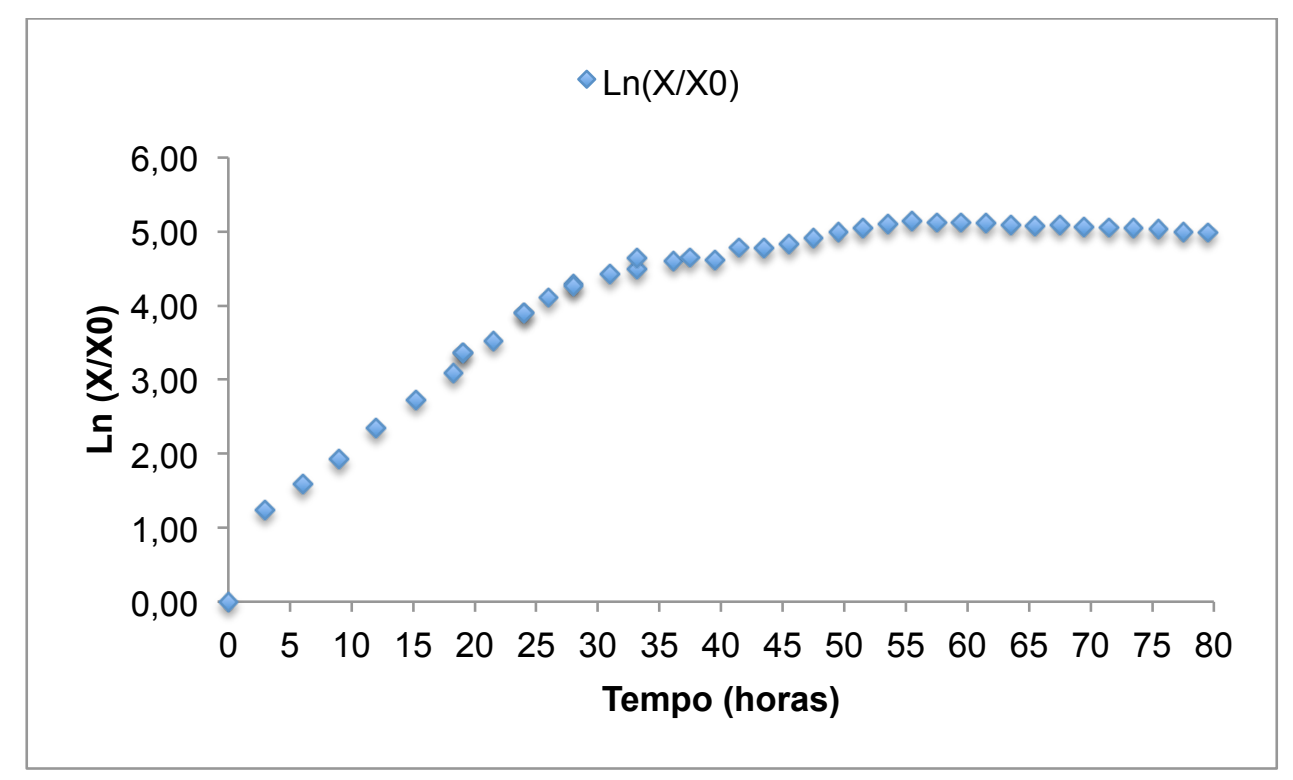

Figura 44 - Ensaio 3: Regressão linear de $\operatorname{Ln}\left(X / X_{0}\right)$ em função do tempo de cultivo de Pseudomonas putida sp. em regime de batelada alimentada sob vazão exponencial seguido de sorção de cobre 


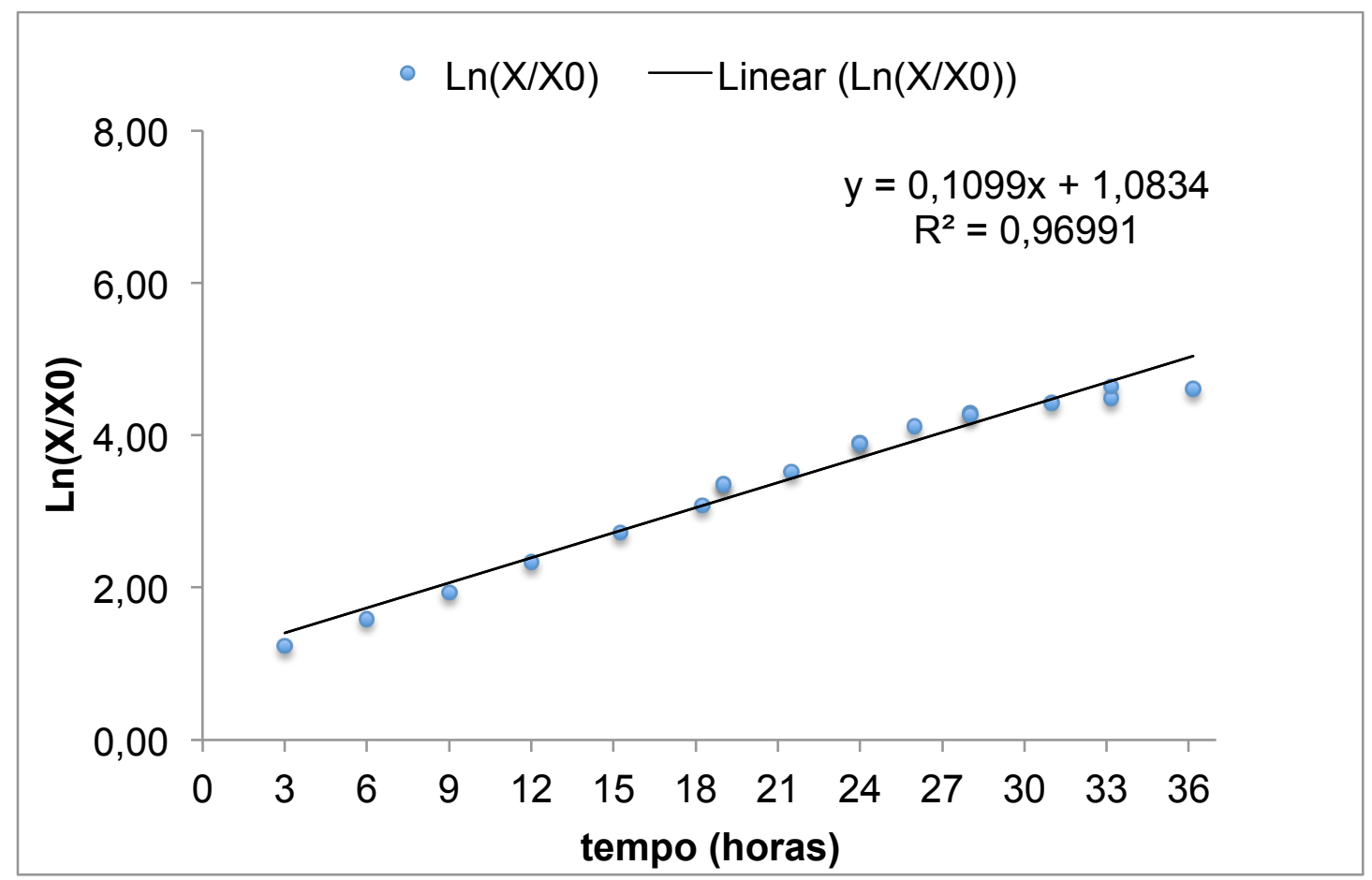

Figura 45 - Ensaio 3: Regressão linear com a linha de tendência de $\operatorname{Ln}\left(X / X_{0}\right)$ no cultivo com alimentação exponencial de glicerol e nutrientes para o intervalo de $3-36$ horas no ensaio de Pseudomonas putida sp. em regime de batelada alimentada sob vazão exponencial seguido de sorção de cobre

Com a diminuição do valor de $\mu$ a partir de 37,5 horas de cultivo, foi iniciada a adição de pulsos, a cada 2 horas, de $139 \mathrm{mg}$ de cobre na forma de solução de sulfato de cobre. Foram realizados 21 pulsos de cobre, totalizando a adição de 2923 mg de $\mathrm{Cu}^{2+}$ no reator. A Tabela 25 apresenta as concentrações de cobre acumulado no reator logo após cada pulso. 
Tabela 25 - Ensaio 3: Concentração de $\mathrm{Cu}^{2+}$ acumulada logo após cada pulso

\begin{tabular}{ccc}
\hline $\begin{array}{c}\text { Número de } \\
\text { Pulsos }\end{array}$ & $\begin{array}{c}\text { Concentração de } \mathbf{C u}^{2+} \\
\text { acumulada no Reator } \\
\text { (mg/L) }\end{array}$ & $\begin{array}{c}\text { Concentração de } \mathbf{C u}^{2+} \\
\text { acumulada no Reator } \\
\text { (mM) }\end{array}$ \\
\hline 1 & 80,48 & 1,27 \\
2 & 154,70 & 2,43 \\
3 & 229,50 & 3,61 \\
4 & 302,67 & 4,76 \\
5 & 362,58 & 5,70 \\
6 & 381,45 & 6,00 \\
7 & 468,56 & 7,37 \\
8 & 540,70 & 8,50 \\
9 & 614,25 & 9,66 \\
10 & 689,26 & 10,84 \\
11 & 765,76 & 12,04 \\
12 & 843,82 & 13,27 \\
13 & 923,46 & 14,52 \\
14 & 1004,75 & 15,80 \\
15 & 1087,73 & 17,10 \\
16 & 1172,46 & 18,43 \\
17 & 1258,99 & 19,80 \\
18 & 1347,38 & 21,19 \\
19 & 1437,70 & 22,61 \\
20 & 1530,00 & 24,06 \\
21 & 1624,35 & 25,54 \\
\hline
\end{tabular}

O crescimento bacteriano cessou às 55,5 horas de cultivo, instante posterior ao décimo pulso de cobre, possivelmente pela inibição do cobre acumulado no meio, como apresentando na Figura 46 (massa de células em função do tempo). $O$ glicerol continuou a ser consumido entre o intervalo de 55,5 horas até final do cultivo em 79,5 horas. Novamente, este consumo pode indicar que o glicerol está sendo utilizado para produzir energia necessária para o processo de bioacumulação, o qual requer gasto energético como descrito por Gravilescu (2004), Lemos et al. (2008) e Volesky (2007). 


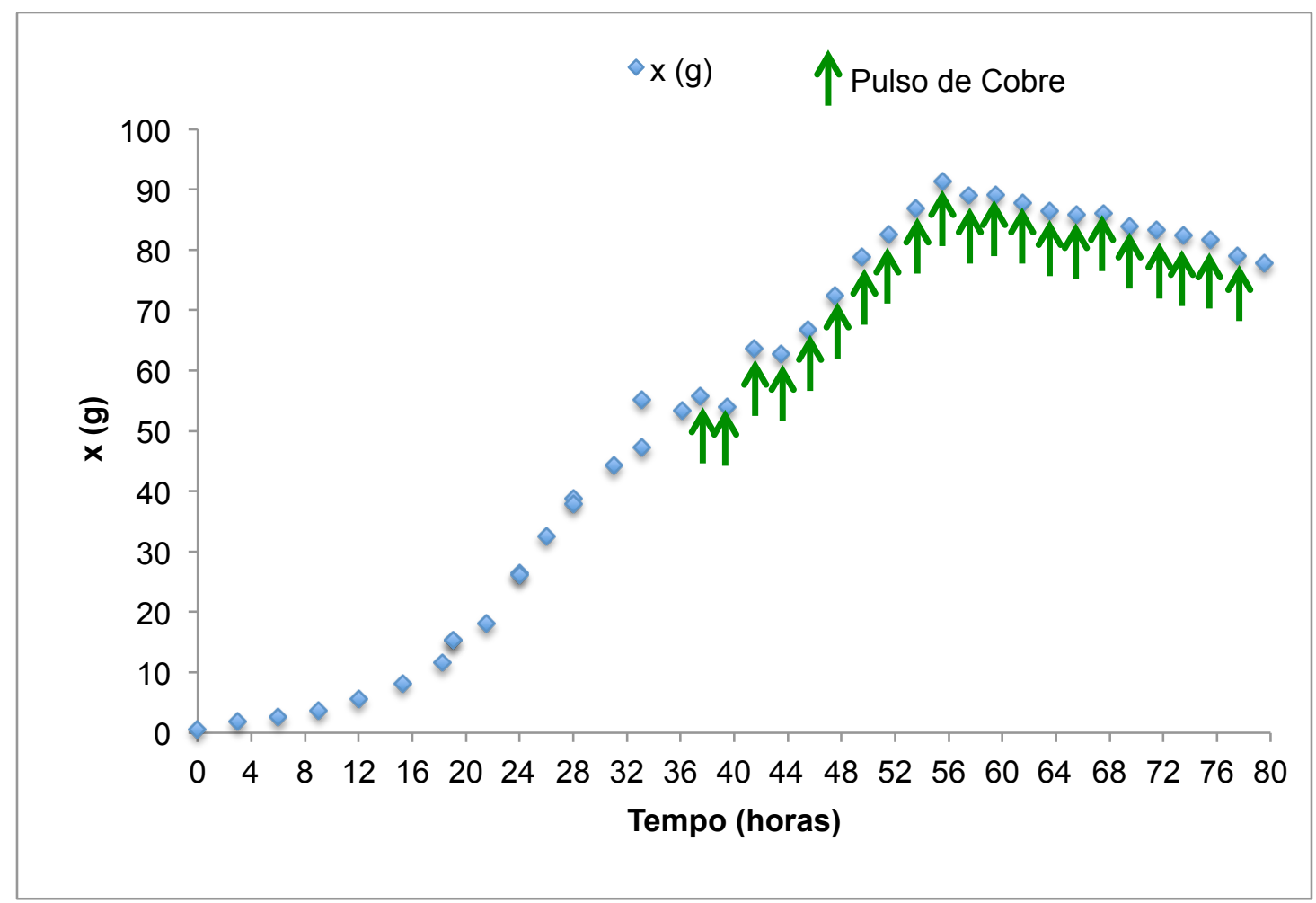

Figura 46 - Ensaio 3: Massa de células, $x$, em função do tempo de cultivo de Pseudomonas putida sp. em regime de batelada alimentada sob vazão exponencial seguido de sorção de cobre

Os valores de adsorção de cobre, $\mathrm{Q}$, foram crescentes com a adição dos pulsos do metal, como apresentado na Tabela 31. O maior valor de $Q$ foi da ordem de $32 \mathrm{mg} / \mathrm{g}$ e a massa total de cobre sorvido foi de 2,54 g a qual corresponde a $86 \%$ da massa de cobre aportada à suspensão celular.

Foi necessário encerrar o cultivo em 79,5 horas devido à formação de espuma, a qual não foi possível controlar com a adição de antiespumante, resultando perda de meio de cultivo pelo condensador. A elevação da viscosidade do meio e formação de espuma densa é resultado da liberação da proteína em virtude da lise celular, provavelmente, devida ao cobre acumulado na célula. 
Tabela 26 - Adsorção de Cobre no Ensaio 3

\begin{tabular}{ccccc}
\hline $\begin{array}{c}\text { Número de } \\
\text { Pulsos }\end{array}$ & $\begin{array}{c}\text { Tempo de } \\
\text { Cultivo (h) }\end{array}$ & $\begin{array}{c}\text { Tempo após a adição da } \\
\text { solução de CuSO } \\
\text { (h) } 7 \mathrm{H}_{2} \mathbf{O}\end{array}$ & $\begin{array}{c}\mathbf{Q}\left(\mathbf{m g ~ d e ~} \mathbf{C u}^{2+} / \mathbf{g}\right. \\
\text { de células secas) }\end{array}$ & $\mathbf{X ( g / L )}$ \\
\hline 1 & 39,50 & 2 & 1,54 & 31,18 \\
2 & 41,50 & 4 & 2,52 & 35,30 \\
3 & 43,50 & 6 & 3,88 & 34,50 \\
4 & 45,50 & 8 & 5,19 & 36,30 \\
5 & 47,50 & 10 & 6,19 & 37,70 \\
6 & 49,50 & 12 & 5,48 & 42,20 \\
7 & 51,50 & 14 & 7,72 & 39,70 \\
8 & 53,50 & 16 & 8,65 & 42,22 \\
9 & 55,50 & 18 & 10,19 & 44,80 \\
10 & 57,50 & 20 & 12,51 & 44,10 \\
11 & 59,50 & 22 & 12,80 & 44,60 \\
12 & 61,50 & 24 & 14,12 & 44,70 \\
13 & 63,50 & 26 & 16,28 & 44,00 \\
14 & 65,50 & 28 & 17,44 & 44,20 \\
15 & 67,50 & 30 & 18,90 & 44,80 \\
16 & 69,50 & 32 & 21,10 & 44,20 \\
17 & 71,50 & 34 & 22,76 & 44,30 \\
18 & 73,50 & 36 & 24,74 & 44,35 \\
19 & 75,50 & 38 & 26,83 & 44,44 \\
20 & 77,50 & 40 & 29,35 & 43,40 \\
21 & 79,50 & 42 & 32,57 & 43,20 \\
\hline
\end{tabular}

Foram coletas amostras de células antes da adição de cobre e nos pulsos de número 15 e 21, para microscopia de transmissão eletrônica. A Figura 47 apresenta a célula antes da adição de cobre e a Figura 48 apresenta as células no pulso de número 15 e as Figuras 49 e 50 apresentam-nas no pulso de número 21.

Antes da adição do cobre, verifica-se que a célula está intacta, sem depósitos de metal na membrana e internamente (Figura 49).

Verifica-se a presença de cobre aderido na membrana e também dentro da célula, ou seja, a bactéria Pseudomonas putida sp. apresenta a capacidade de 
sorção de cobre utilizando os processos de adsorção e bioacumulação. Nas Figuras 49 e 50 , verifica-se a lise celular, possivelmente devido ao cobre, o que corrobora a hipótese supracitada de aumento de viscosidade do meio devido ao conteúdo celular extravasado para o meio.

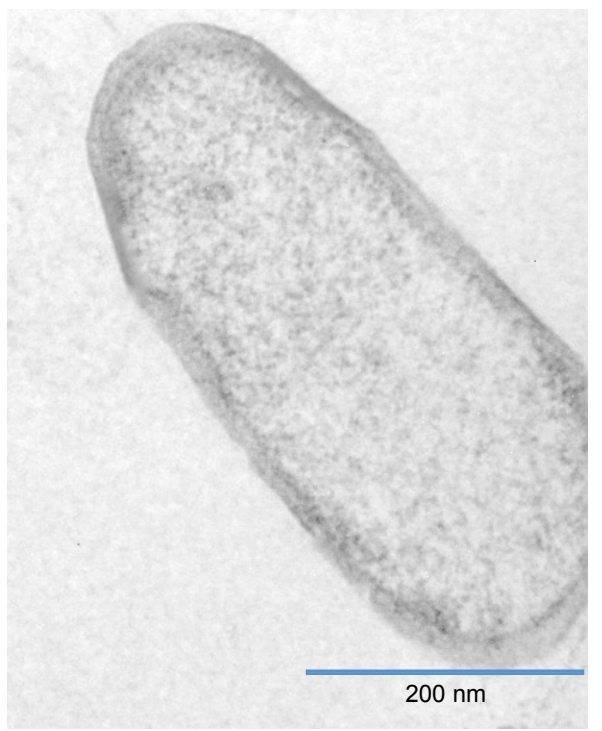

Figura 47 - Imagem obtida por microscopia de transmissão eletrônica da Pseudomonas putida sp., ampliada 40.000 vezes, em amostragem realizada antes da adição de cobre, correspondente às $35,5 \mathrm{~h}$ do cultivo no Ensaio 3 


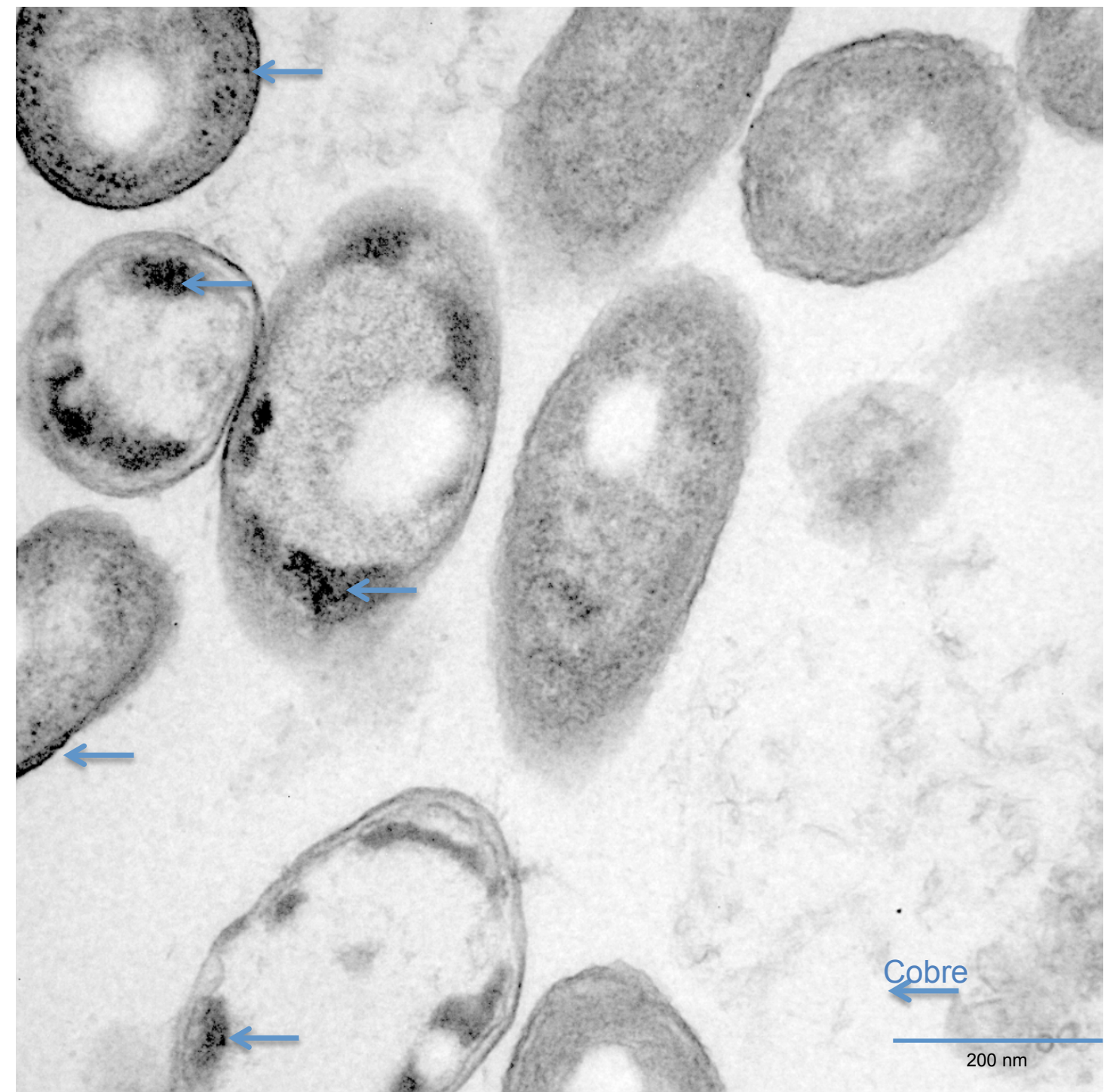

Figura 48 - Imagem obtida por microscopia de transmissão eletrônica da Pseudomonas putida sp., ampliada 40.000 vezes, em amostra correspondente ao pulso de número 15 , às $65,5 \mathrm{~h}$ do cultivo no Ensaio 3 


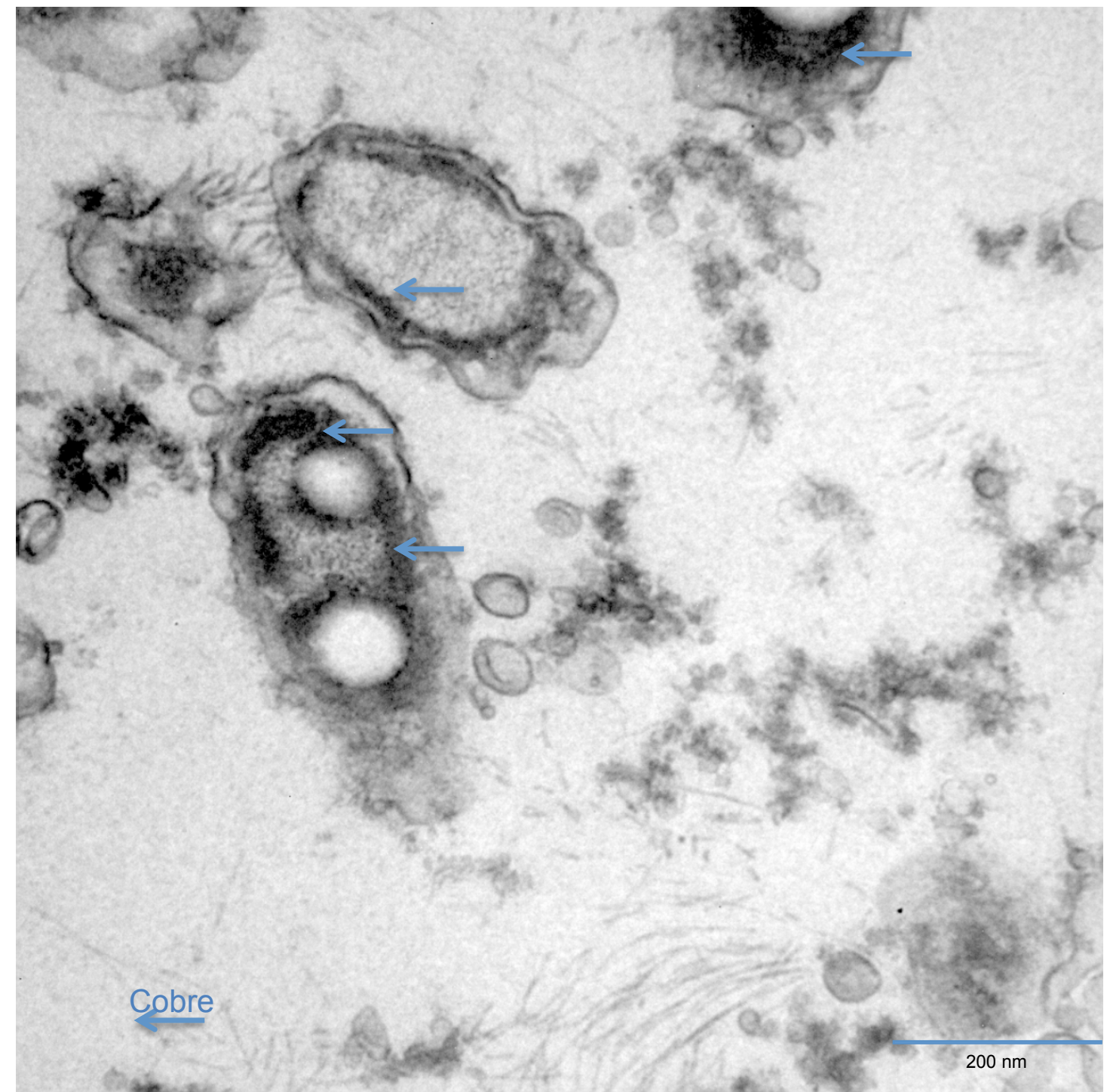

Figura 49 - Imagem obtida por microscopia de transmissão eletrônica da Pseudomonas putida sp., ampliada 40.000 vezes, em amostra correspondente ao pulso de número 21 , às $77,5 \mathrm{~h}$ do cultivo no Ensaio 3 


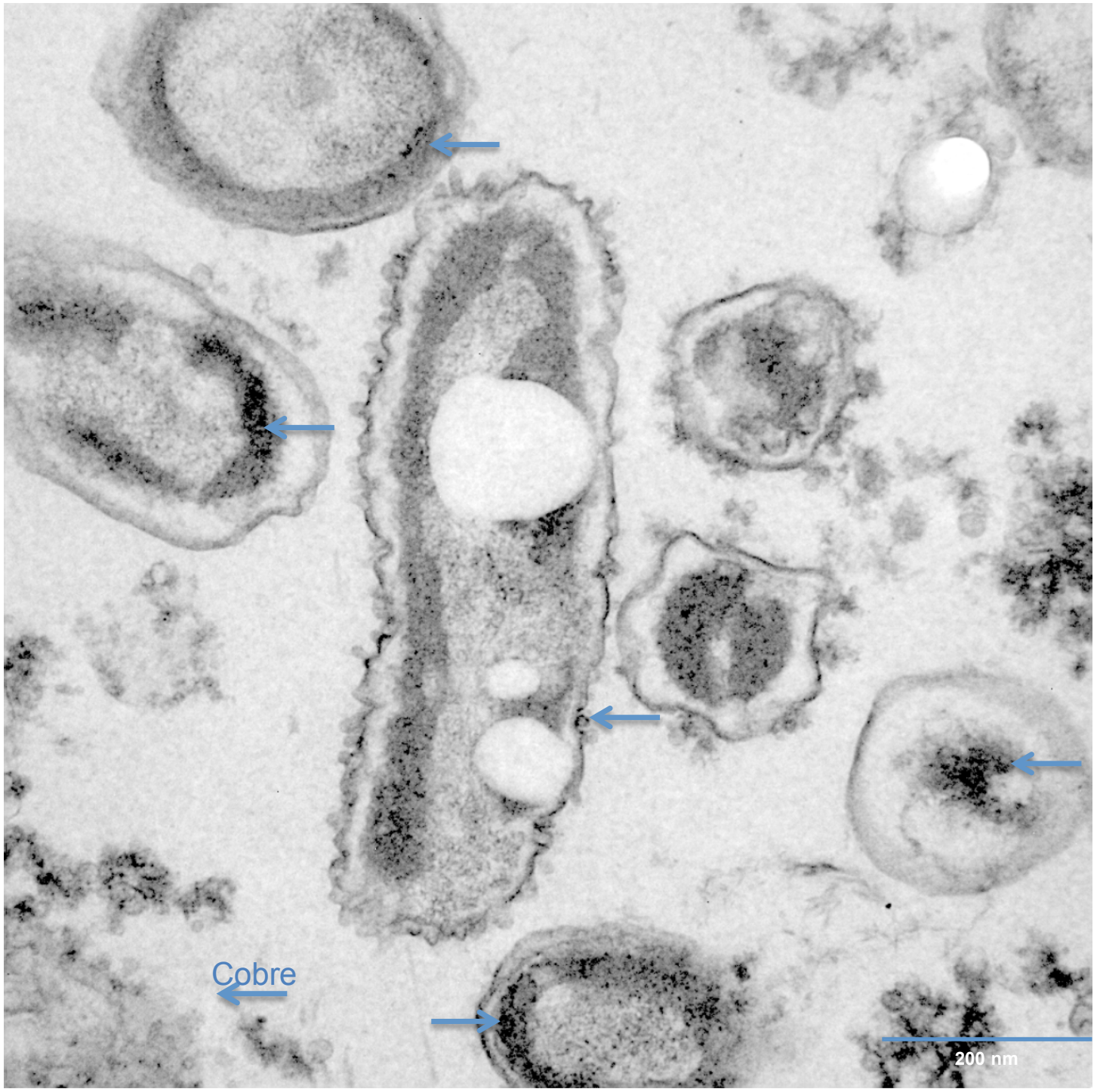

Figura 50 - Imagem obtida por microscopia de transmissão eletrônica da Pseudomonas putida sp., ampliada 40.000 vezes, em amostra correspondente ao pulso de número 21 , às $77,5 \mathrm{~h}$ do cultivo no Ensaio 3

\subsubsection{Resumo da Sorção de Cobre em Pseudomonas putida sp.}

Nas condições empregadas no cultivo de Pseudomonas putida sp. em reator, a inibição resultante da adição de cobre, verificada em termos de redução da velocidade de crescimento, variou com a forma de adição do cobre, a carga adicionada e a relação entre massa de cobre e concentração celular. Por exemplo, 652 ppm de $\mathrm{Cu}^{2+}$, em uma única adição, a um meio com $X$ de $31,5 \mathrm{~g} / \mathrm{L}$, resultou em inibição do crescimento. Na adição de $\mathrm{Cu}^{2+}$ por meio de pulsos foi necessário acumular a concentração de 439 ppm $\mathrm{Cu}^{2+}$, com valor de $\mathrm{X}$ de 45,10 g/L no ensaio 2 
e $689 \mathrm{ppm}$ de $\mathrm{Cu}^{2+}$ com valor de $\mathrm{X}$ de $44,10 \mathrm{~g} / \mathrm{L}$ no ensaio 3 para inibição do crescimento.

Nos ensaios para sorção de cobre por Pseudomonas putida sp. em meio de cultura e em processo de reprodução celular, itens 5.7, 5.8 e 5.9, não foi verificado o mesmo valor de $Q_{e}$ dos ensaios em condições idealizadas, a saber, $58,78 \mathrm{mg} / \mathrm{g}$, e nem sequer valores próximos, pois, o máximo valor de $Q$ determinado nos cultivos foi de $32,6 \mathrm{mg} / \mathrm{g}$. As diferentes condições nos cultivos dos itens 5.7 a 5.9 em relação aos ensaios para isotermas, tais como pH (5 nos ensaios para determinação das isotermas e 7 nos cultivos em reator), força iônica, estado fisiológico das células, têm influência sobre a capacidade de sorção de cobre pelas células. Por estas razões, não é adequado fazer comparações entre os valores de $Q$, e sim, apenas cotejar esses valores. 


\section{CONCLUSÕES}

- Foram isoladas duas bactérias de amostras de solo e águas da área da Mina de Sossego (Canaã de Carajás, PA), capazes de crescer em meio sintético adicionado de no máximo $7 \mathrm{mM}$ de $\mathrm{Cu}^{2+}$ e $5 \mathrm{mM}$ de $\mathrm{Ni}^{2+}$.

- As duas bactérias selecionadas, Pseudomonas putida BHUJY14 e Cupriavidus metallidurans BMPEZ, foram identificadas por meio do sequenciamento do gene 16 S rRA com 99\% de similaridade

- O meio Ramsay 2006-2 adicionado de glicerol em substituição a glicose, promoveu o melhor crescimento de Pseudomonas putida sp., em comparação aos meios TSM, M9, M63, Ramsay 2006-1, tendo em vista $Y_{\mathrm{X} / \mathrm{S}}$ de $0,51 \mathrm{~g} / \mathrm{g}$ e $\mu_{\max }$ de $0,11 \mathrm{~h}^{-1}$, em cultivos em incubador rotativo.

- Ensaios de sorção em meio a água ultra-pura, $\mathrm{pH} 5$, temperatura de $30{ }^{\circ} \mathrm{C}$, tendo concentrações de cobre entre 0,12 a 2,06 mM, resultaram máxima capacidade de sorção, $Q_{e}$, de Pseudomonas putida sp. de $57,78 \mathrm{mg} / \mathrm{g}$, após duas horas de contato entre células e cobre.

- Na etapa de cultivo em reator, foi necessário empregar outro meio de cultivo, que não o meio Ramsay 2006-2 previamente selecionado, dado que a elevada concentração de fosfatos neste meio promove a precipitação do sal de cobre.

- Pseudomonas putida sp. cultivada em reator, regime de batelada, meio MM acrescido de gicerol, apresenta $Y_{X / S}$ de $0,46 \mathrm{~g} / \mathrm{g}$ e $\mu_{\max }$ de $0,11 \mathrm{~h}^{-1}$, portanto, um meio tão adequado quanto o meio Ramsay 2006-2 previamente selecionado.

- Elevada concentração celular de Pseudomonas putida sp., X de $96 \mathrm{~g} / \mathrm{L}$, foi atingida quando do cultivo em reator em regime de batelada alimentada por pulsos, meio MM acrescido de glicerol, com correspondente $Y_{\mathrm{X} / \mathrm{s}}$ de $042 \mathrm{~g} / \mathrm{g}$. Este resultado foi possível após a modificação do sistema de aeração do reator da Infors.

- Células de Pseudomonas putida sp. em fase exponencial de crescimento, isto 
é, sob máximo valor de $\mu$, apresentaram maior capacidade de sorção de cobre, $\mathrm{Q}, 26 \mathrm{mg} / \mathrm{g}$, em comparação às células da fase estacionária, cujo valor de $Q$ foi de $21 \mathrm{mg} / \mathrm{g}$.

- Nas condições empregadas no cultivo de Pseudomonas putida sp. em reator no item 5.9, a inibição resultante da adição de cobre, verificada em termos de redução da velocidade de crescimento, variou com a forma de adição do cobre, a carga adicionada e a relação entre massa de cobre e concentração celular, os valores de inibição obtidos foram 20,70; 9,73; e 15,62 mg Cu${ }^{2+}$ acumulado / $\mathrm{g}$ de células secas.

- Em estágios avançados do processo de sorção de cobre por Pseudomonas putida sp., ocorre lise celular, a qual deve ser evitada pois dificulta subsequentes operações de concentração da biomassa e recuperação do metal adsorvido e bioacumulado. 


\section{REFERÊNCIAS ${ }^{1}$}

ALTSCHUL, S. F. et al. Gapped BLAST and PSI-BLAST: a new generation of protein database search programs. Nucleic Acids Res., v. 25, p. 3389-3402, 1997.

ANDREAZZA, R. Potencial do uso de bactérias e plantas para a remediação de cobre em áreas de vitivinicultura e de rejeito de mineração de cobre no Rio Grande do Sul. 2009. 126 f. Tese (Doutorado em Ciência do Solo) - Faculdade de Agronomia, Universidade Federal do Rio Grande do Sul. Porto Alegre, 2009.

ANNUAR, M. S. M. et al. Ammonium Uptake and Growth Kinetics of Pseudomonas putida PGAI. Asia-Pac. J. Mol. Biol., v. 14, n. 1, p. 1-10, 2006.

AUSUBEL, F. M. et al. Current Protocols in Molecular Biology, Greene Publishing Associates/Wiley Interscience, New York, 1987.

BARBOSA, C. R. Avaliação do glicerol proveniente da fabricação do biodiesel como substrato para produção de endotoxinas por Bacillus thuringiensis var. israelensis. 2009. 135 f. Dissertação (Mestrado em Biotecnologia Industrial) Escola de Engenharia de Lorena da Universidade de São Paulo, São Paulo, 2009.

BORRERO-DE-ACUÑA, J. M. et al. Production of medium chain length polyhydroxyalkanoate in metabolic flux optimized Pseudomonas putida. Microb. cell Fact., v. 13, n. 88, 2014.

BRANDL, H. Metal-Microbe-Interactions and their biotechnological applications for mineral waste treatment. ANAIS DO 7TH WORLD CONGRESS ON RECOVERY, RECYCLING AND RE-INTEGRATION, versão digital, Beijing, China, 2005.

CÁNOVAS, D.; CASES, I.; DE LORENZO, V. Heavy metal tolerance and metal homeostasis in Pseudomonas putida as revealed by complete genome analysis. Environ. Microbiol., v. 5, n. 12, p. 1242-56, 2003.

CARMINATTI, C. A. Ensaios de Hidrólise Enzimática da Lactose em Reator a Membrana Utilizando Beta-Galactosidase Kluyveromyces lactis. 2001. $66 \mathrm{f}$. Dissertação (Mestrado em Engenharia Química) - Centro Tecnológico, Universidade Federal de Santa Catarina. Florianópolis, 2001.

\footnotetext{
${ }^{1}$ De acordo com: ASSOCIAÇÃO BRASILEIRA DE NORMAS TÉCNICAS. NBR 6023: informação e documentação: referências: elaboração. Rio de Janeiro, 2002.
} 
CASTRO, I. A. P. Systems Biotechnology of Pseudomonas putida for the enhanced production of Polyhydroxyalkanoates: a rational approach for strain and bioprocess engineering. 2012. 166 p. [dissertation] - Von der Fakulät fur Lebenswissenschaften der Technischen Universwität Carolo-Wilhelmina, Braunschweig, 2012.

CHEN, X. C. et al. Biosorption of cooper(II) and zinc(II) from aqueous solution by Pseudomonas putida CZ1. Coll. Surf. B: Bioint., v. 46, p. 101-107, 2005.

CHEN, W. M. et al. Metal biosorption capability of Cupriavidus metaiwanesis and its effects on heavy metal removal by nodulated Mimosa pudica. J. Hazard. Mat., v. 151, p. 364-371, 2008.

DILLIS, S. S. et al. Carbohydrate transport in bacteria. Microbiol. Rev., v. 44, p. 385418, 1980.

DINIZ, S. C. et al. High-Cell-Density Cultivation of Pseudomonas putida IPT 046 and Medium-Chain-Length Polyhydroxyalkanoate Production From Sugarcane Carbohydrates. Appl. Biochem. and Biotechnol., v. 119, 2004.

DINU, L. D.; ANGHEL, L.; JURCOANE, S. Isolation of heavy metal resistant bacterial strains from the battery manufactured polluted environment. Rom. Biotechnol. Lett., v. 16, n. $6,2011$.

DÖNMEZ, G.; AKSU, Z. The effect of copper (II) ions on the growth and bioaccumulation properties of some yeasts. Process Biochem., v. 35, n. 1-2, p. 135142, 1999.

FAN, J.; OKAYAY, T. O.; RODRIGUES, D. F. The sybergism of temperature, pH and growth phases on heavy metal biosorption by two environmental isolates. J. Hazard. Mat., v. 279, p. 236-243, 2014.

FOSSO-KANKEU, E. et al. Prediction of metal-adsorption behaviour in the remediation of water contamination using indigenous microorganisms. J. Environ. Manag., v. 92, p. 2786-2793, 2011.

GADD, G. M. Metals, minerals and microbes: geomicrobiology and bioremediation. Microbiology, v. 156, p. 609-643, 2010. 
GAVRILESCU, M. Removal of Heavy Metals from the Environment by Biosorption. Eng. Life Sci., v. 3, p. 219-232, 2004.

GAYLARDE, C. C.; BELLINASO, M. L.; MANFIO, G. P. Biorremediação: Aspectos biológicos e técnicos da biorremediação de xenobióticos. Biotecnolog. Cienc. Desenvolv., n. 34, jan/jun 2005.

GRASS, G. et al. FieF (YiiP) from Escherichia coli mediates decreased cellular accumulation of iron and relieves iron stress. Arch. Microbiol., v. 183, p. 9-18, 2005.

HE, L. M.; TEBO, B. M.; Surface charge properties of and $\mathrm{Cu}(\mathrm{II})$ adsorption by spores of the marine Bacillus sp. strain SG-1. Appl. Environ. Microbiol., v. 64, p. 1123-1129, 1998.

HUANG, C. C. et al. Polypeptides for heavy-metal biosorption: capacity and specificity of two heterogeneous MerP priteins. Enzyme Microb. Technol., v. 33, p. 379-385, 2003.

HUANG, Q; CHEN, W; XU, L. Adsorption of Copper and Cadmium by Cu- and CdResistant Bacteria and Their Composites with Soil Colloids and Kaolinite. Geomicrobiol. J., v. 22, p. 227-236, 2005.

JUNILAN, $Q$ et al. Comparative Study on the $\mathrm{Ni}^{2+}$ Biosorption Capacity and Properties of Living and Dead Pseudomonas putida Cells. Iran. J. Chem. Chem. Eng., v. 28, n. 1, 2010.

KAPOOR, A.; VIRARAGHAVAN, T.; CULLIMORE, D. R. Removal of heavy metals using the fungus Aspergillus niger. Bioresource Technol., v. 70, n. 1, p. 95-104, 1999.

KIM, G. J. et al. High Cell Density Cultivation of Pseudomonas putida BM01 Using Glucose. J. Microbiol. Biotechnol., v. 6, n. 3, p. 221-224, 1996.

KUMAR, A. et al. Review on Bioremediation of Polluted Environment: A Management Tool. Int. J. Environ. Sci., v. 1, n. 6, 2011.

LANGLEY, S.; BEVERIDGE, T. J. Effect of O-side-chain-lipopolysaccharide chemistry on metal binding. Appl. Environ. Microbiol., v. 65, p. 489-498, 1999. 
LEE, S. Y. et al. Production of Medium-Chain-Length Polyhydroxyalkanoates by High-Cell-Density Cultivation of Pseudomonas putida Under Phosphorus Limitation. Biotechnol. and Bioeng., v. 68, n. 4, 2000.

LEMOS, J. L.; CARLOS, M. C.; FARIAS Y. P. T. M. M.; SANTOS, R. L. C. Revisão acerca da utilização de microrganismos na biorremediação de rejeitos industriais contendo metais pesados. Série Tecnologia Ambiental, v. 43, CETEM/MCT, 2008.

LUDWIG, W.; SCHLEIFER, K. H. Bacterial phylogeny based on 16 s and 23 s Rrna sequence analysis. FEMS Microbiol., Rev. 15: p. 155-173, 1994.

MAYERS, I. T.; BEVERIDGE, T. J. The sorption of metals to Bacillus subtilis walls from dilute solutions and simulated Hamilton Harbour (Lake Ontario) water. Can. J. Microbiol., v. 35, p. 764-770, 1989.

MERGEAY, M. et al. F. Alcaligenes eutrophus $\mathrm{CH} 34$ is a facultative chemolithotroph with plasmid-bound resistance to heavy metals. J. Bacteriol., v. 162, p. 328-334, 1985.

NIES, D. H.; SILVER, S. Ion eflfux systems involved in bacterial metal resistances. J. Indust. Microbiol., v. 14, p. 186-199, 1995.

NIES, D. H. Microbial heavy-metal resistance. Appl. Microbiol. Biotechnol., v. 51, p. 730-750, 1999.

NINGTHOUJAM, D. S.; SHOVARANI, N. Isolation and Characterization of a Pseudomonas aeruginosa Strain DNI Degrading p-Nitrophenol. Res. J. Microbiol., v. 3, n. 5, p. 345-351, 2008.

OLUKOYA, D. K. et al. Isolation and characterization of heavy metals resistant bacteria from Lagos Lagoon. Folia Microbiol., v. 42, n. 5, p. 441-444, 1997.

PANICO, R.; POWELL, W. H.; RICHER, J. C. A Guide to IUPAC Nomenclature of Organic Compounds (recommendations 1993) - A guide to the Blue Book. Oxford, Blackwell Science, 1993.

PAPANIKOLAOU, S. et al. Biotechnological valorization of raw glycerol discharged after bio-diesel (fatty acid methyl esters) manufacturing process: Production of 1,3propanediol, citric acid and single cell oil. Biomass Bioenerg., v. 32, p. 60-71, 2008. 
PATHAK, A.; DASTIDAR, M. G.; SNEEKRISHNAN, T. R. Bioleachingof heavy metals from sewage sludge: A review. J. Environ. Manage., v. 90, n. 8, p. 2343-2353, 2009.

PEREIRA J.R.N.; BOM, E.P.S.; FERRARA, M.A. Tecnologia de bioprocessos. Escola de Química/UFRJ, 62p, 2008.

PERRY, H.; CHILTON, C. H. Chemical Engineers' Handbook. 5.ed. Tokyo: McGraw-Hill, Kogakusha, 1973. 547 p.

PINO, G.A.H. Biossorção de Metais Pesados Utilizando Pó da Casca de Coco Verde (Cocos nucifera). 2005. 113 f. Dissertação (Mestrado em Engenharia Metalúrgica) - PUC-Rio. Rio de Janeiro, 2005.

PIVELI, R.P.; KATO, M.T. Ferro, Manganês e Metais Pesados em Águas. In: Qualidade das águas e poluição: aspectos físicos-químicos. São Paulo: $A B E S$, p. 173-187, 2005.

RAJBANSHI, A. Study on heavy metal resistant bacteria in guheswori sewage treatment plant. Our Nature, v. 6, p. 52-57, 2008.

RIESENBERG, D.; GUTHKE, R. High-cell-density cultivation of microorganisms. Appl. Microbiol. Biotechnol., v. 51, p. 422-430, 1999.

ROANE, T.M.; PEPPER, I.L. Microbial responses to environmentally toxic cadmium. Microbiol. Ecol., v. 38, p. 358-64, 2000.

RUCHTI, G; DUNN, I. J.; BOURNE, J. R. Comparison of dynamic electrode methods for the measurement of KLa. Biotechnol. Bioeng., v. 23, p. 277-290, 1981.

SCHARFMAN, A. et al. Adhesion of Pseudomonas aeruginosa to respiratory mucins and expression of mucin-binding proteins are increased by limiting iron during growth. Infect. Immun., v. 64, n. 12, p. 5417-5420, 1996.

SKOWRONSKI, T.; PIRSZEL, J.; SKOWRONSKA, B. P. Heavy metal removal by the waste biomass of Penicillium chrysogenum. Water Qual. Res. J. Can., v. 36, n. 4, p. 793-803, 2001. 
STACKENBRANDT, E.; GOEBEL, B.M. Taxonomic note: a place for DNA-DNA reassociation and 16S rRNA sequence analysis in the present species definition in bacteriology. Int. J. Syst. Evol. Microbiol., v. 44, p. 846-849, 1994.

SUN, Z.; RAMSAY, J.A.; GUAY, M.; RAMSAY, B.A. Automated feeding strategies for high-cell-density fed-batch cultivation of Pseudomonas putida KT2440. Appl. Microbiol. Biotechnol., v. 71, p. 423-431, 2006.

SUN, Z. et al. Enhanced yield of medium-chain-length polyhydroxyalkanoates from nonanoic acid by co-feeding glucose in carbon-limited, fed-batch culture. $\mathbf{J}$. Biotechnol., v. 143 p. 262-267, 2009.

TACIRO, M. K. Processo contínuo de produção de polihidroxialcanoatos de

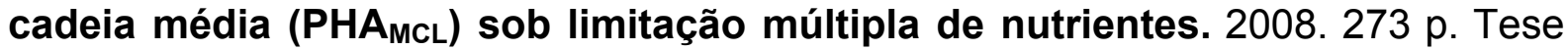
(Doutorado em Biotecnologia) - Programa Interunidades em Biotecnologia USP/IPT/BUTANTAN, Universidade de São Paulo, São Paulo, 2008.

TUNALI, S.; ÇABUK, A.; AKAR, T. Removal of lead and cooper ions from aqueous solutions by bacterial strain isolated from soil. Chem. Eng. J., v. 15, p. 203-211, 2006.

USLU, G; TANYOL, M. Equilibrium and thermodynamic parameters of single and binary mixture biosorption of lead (II) amd cooper (II) ions onto Pseudomonas putida: Effect of temperature. J. Hazard. Mat., v. B135, p. 87-93, 2006.

VEGLIO, F.; BEOLCHINI, F. Removal of metals by biosorption: A review. Hydrometall., v. 44, n. 3, p. 301-316, 1997.

VECCHIO, A. et al. Heavy metal biosorption by bacterial cells. Fresenius. J. Anal. Chem., v. 361, p. 338-342, 1998.

VEGLIO, F.; ESPOSITO, A.; REVERBERI, A. P. Standardization of heavy metal biosorption tests: equilibrium and modeling study. Process Biochem., v. 38, p. 953961, 2003.

VERHOEF, S. et al. Crude glycerol as feddstock for the sustainable production of $p$ hydroxybenzoate by Pseudomonas putida S12. N. Biotechnol., v. 31, n. 1, 2014.

VOLESKY, B.; HOLAN, Z. R. Biosorption of heavy metals. Biotecnol. Prog., v.11, n. 3, p. 235-250, 1995. 
VOLESKY, B. Detoxification of metal-bearing effluents: biosorption for the next century. Hydrometallurgy, v. 59, p. 203-216, 2001.

VOLESKY B. Biosorption and me. Water Res., v. 41, n. 18, p. 4017-2, 2007.

VULLO, D. L. Microorganismos y metales pesados: una interacción en beneficio del medio ambiente. Química Viva, v. 2, n. 3, 2003.

WEBER, W. J. Physicochemical process for water quality control. New York: John Wiley, 1972.

WOLFGANG, M. C. et al. Pseudomonas aeruginosa regulates flagellin expression as part of a global response to airway fluid from cystic fibrosis patients. PNAS, v. 101, $\mathrm{n}$. 17, p. 6664-6668, 2004.

ZOUBOULIS, A.I.; LOUKIDOU, M.X.; MATIS, K.A. Biosorption of toxic metals from aqueous solutions by bacteria strains isolated from metal-polluted soils. Process Biochem., v. 39, p. 909-916, 2004. 


\section{APÊNDICE - Estudo de Transferência de Oxigênio no Reator da Infors Modelo Labfors 5}

Uma vez que não foi possível obter alta densidade celular de Pseudomonas putida sp. possivelmente devido à baixa transferência de oxigênio da fase gasosa para a líquida na configuração padrão do reator da Infors, foi realizado um experimento utilizando o método de Ruchti et al. (1981), que consistiu em determinar o coeficiente de transferência de oxigênio $\left(\mathrm{k}_{\mathrm{L}} \mathrm{a}\right)$, nas mesmas condições de cultivo (temperatura e volume inicial) com água.

Os valores de $k_{L} a$ obtidos para a configuração padrão do reator da Infors mostraram-se baixos, como pode ser observado na Tabela A1.

Tabela A1 - Valores de kıa para o Aspersor da Configuração Padrão do Reator (Formato de "L")

\begin{tabular}{cc}
\hline Agitação (RPM) & $\mathbf{k}_{\mathrm{L}} \mathbf{a}\left(\mathbf{h}^{-1}\right)$ \\
\hline 250 & 37,23 \\
350 & 68,98 \\
450 & 70,16 \\
550 & 74,94 \\
600 & 74,94 \\
\hline
\end{tabular}

Com estes valores de $\mathrm{k}_{\mathrm{L}} \mathrm{a}$, mesmo na agitação máxima, 600 RPM, não seria possível obter alta densidade celular mesmo com injeção de oxigênio puro, conforme a configuração padrão do reator.

Os baixos valores do coeficiente volumétrico de transferência de oxigênio para a fase líquida, proporcionados pelo aspersor em formato de "L" (Figura A1), que é o modelo padrão dos reatores da Infors, se devem ao grande tamanho das bolhas produzidas pelo aspersor. 


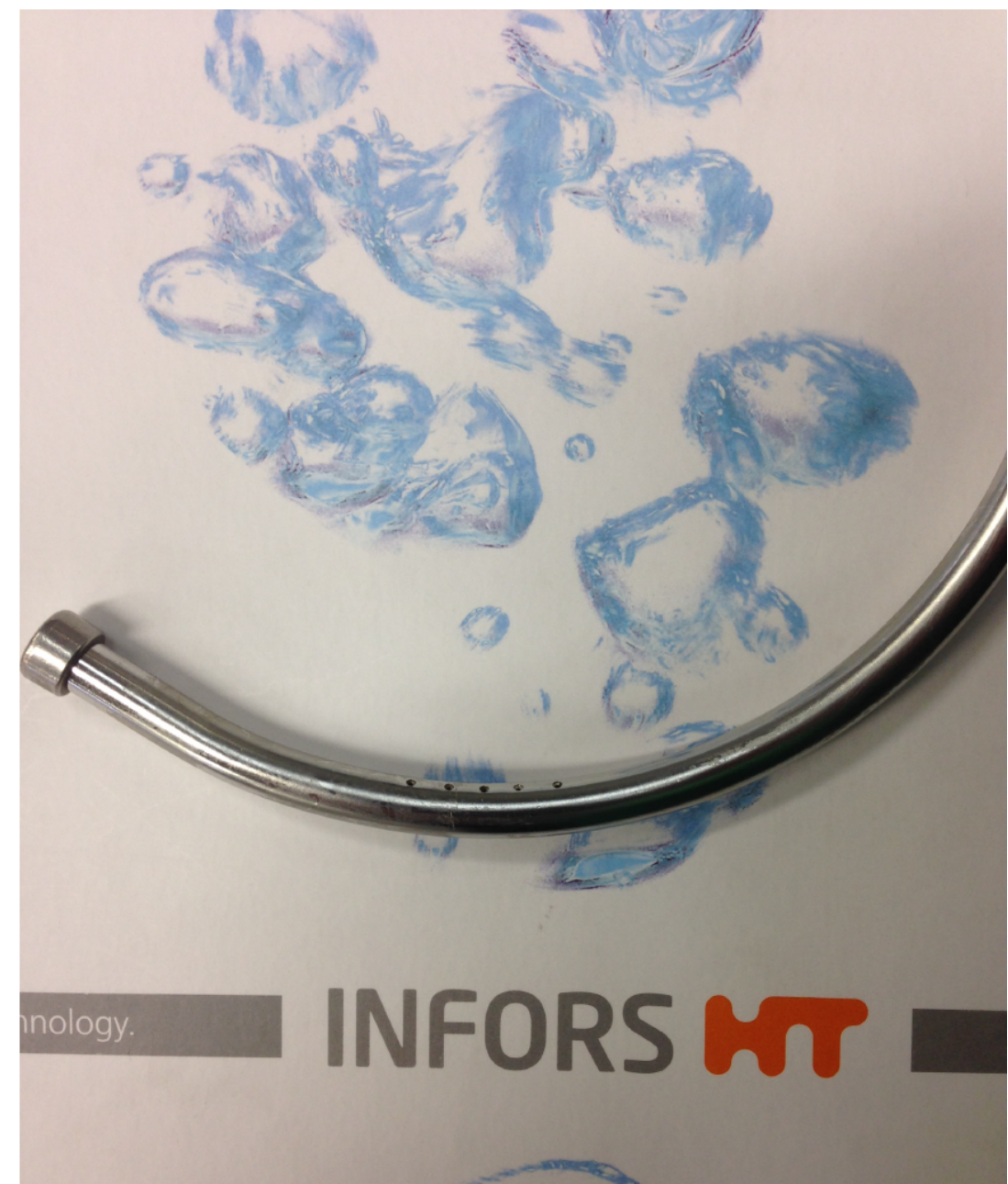

Figura A1 - Aspersor em "L" do Reator da Infors na configuração padrão

A Infors foi consultada sobre os tipos de aspersores e dois novos modelos, anelar e sinterizado (Figuras A2 e A3), estão disponíveis para este modelo de reator e foram importados da Suíça para avaliação. O processo de importação demandou aproximadamente 60 dias. 


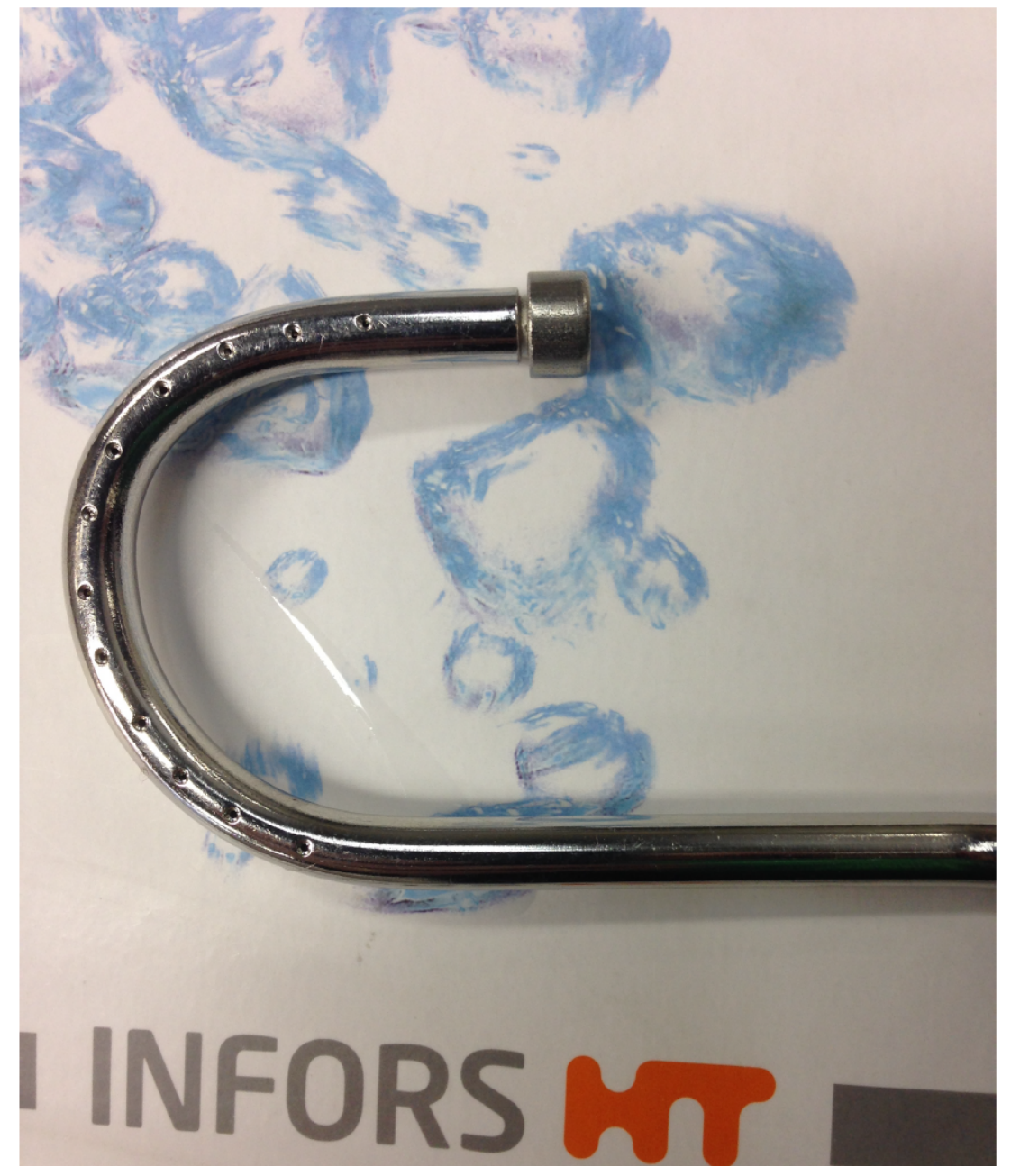

Figura A2 - Aspersor Anelar do Reator da Infors 


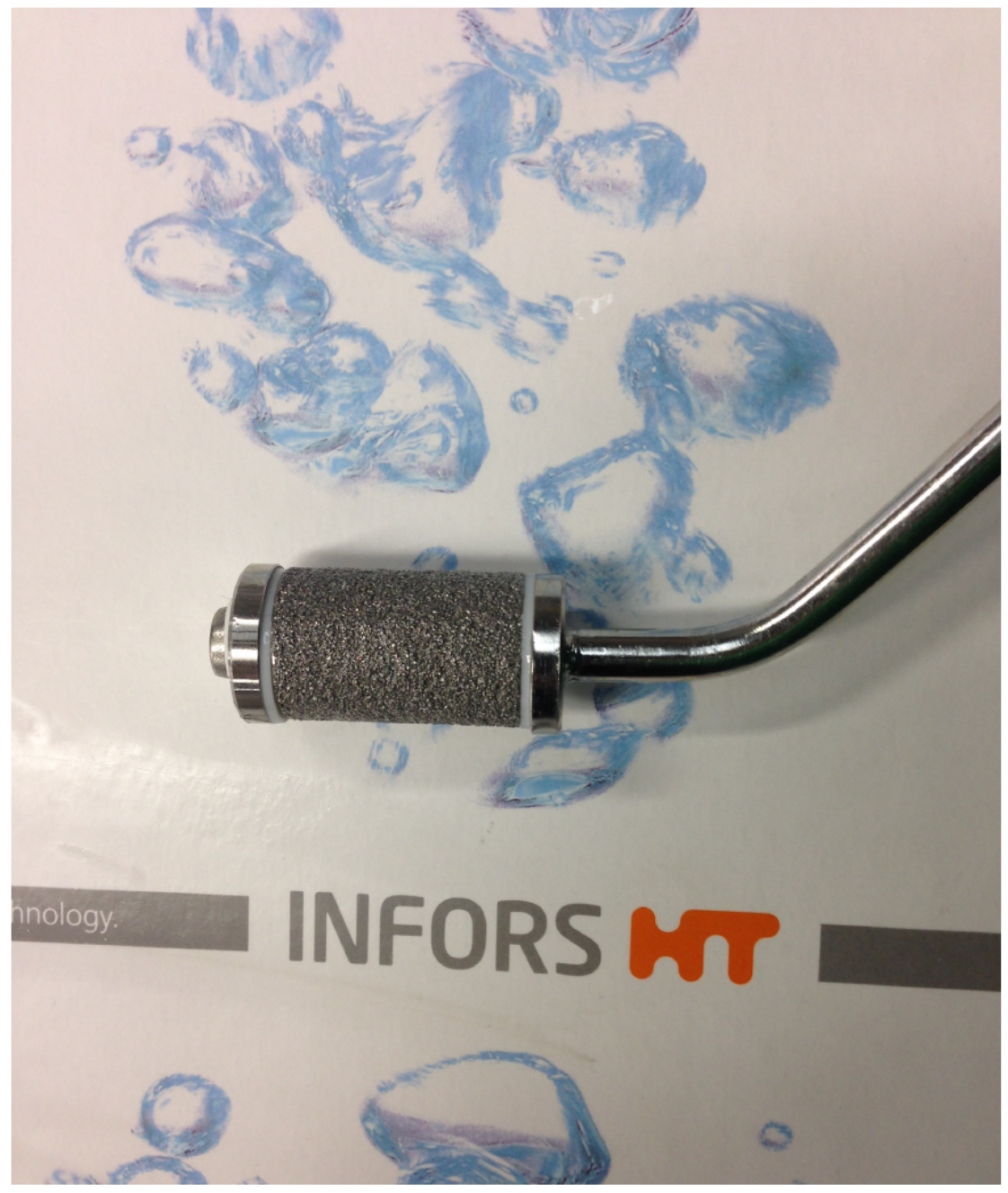

Figura A3 - Aspersor Sinterizado do Reator da Infors

\section{Estudo de Transferência de Oxigênio para os Aspersores Anelar e Sinterizado}

Foram realizados testes para determinar os valores de $\mathrm{k}_{\llcorner} \mathrm{a}$ para os dois novos aspersores.

Os resultados obtidos estão apresentados nas Tabelas A2 e A3. Verificou-se acréscimo nos valores de $\mathrm{k}_{\mathrm{L}} \mathrm{a}$ para o aspersor sinterizado quando comparado com o aspersor em formato de "L" utilizado anteriormente. Já o aspersor anelar apresentou valores menores de $\mathrm{k}_{\mathrm{L}} \mathrm{a}$. Isto já era esperado, pois o aspersor sinterizado é capaz de produzir bolhas de tamanho menor quando comparadas às bolhas dos aspersores em "L" e anelar. 
Tabela A2 - Valores de k $\mathrm{L}$ a para o Aspersor Anelar

\begin{tabular}{cc}
\hline Agitação (RPM) & $\mathbf{k}_{\mathbf{L}} \mathbf{a}\left(\mathbf{h}^{-1}\right)$ \\
\hline 250 & 26,30 \\
350 & 32,19 \\
450 & 50,90 \\
550 & 62,03 \\
600 & 66,64 \\
\hline
\end{tabular}

Tabela A3 - Valores de k $\mathrm{L}$ a para o Aspersor Sinterizado

\begin{tabular}{cc}
\hline Agitação (RPM) & $\mathrm{k}\left\llcorner\mathrm{a}\left(\mathrm{h}^{-1}\right)\right.$ \\
\hline 250 & 48,74 \\
350 & 63,17 \\
450 & 83,54 \\
550 & 83,53 \\
600 & 83,55 \\
\hline
\end{tabular}

Entretanto, este acréscimo ainda seria pequeno para a obtenção de alta densidade celular. Para aumentar mais os valores de $\mathrm{k}_{\mathrm{L}} \mathrm{a}$, a turbina de Rushton (Figura A4), localizada logo abaixo do aspersor, teve sua área aumentada com a adição de pedaços pequenos de mangueiras de silicone de alta rigidez, como pode ser observado na Figura A5. 


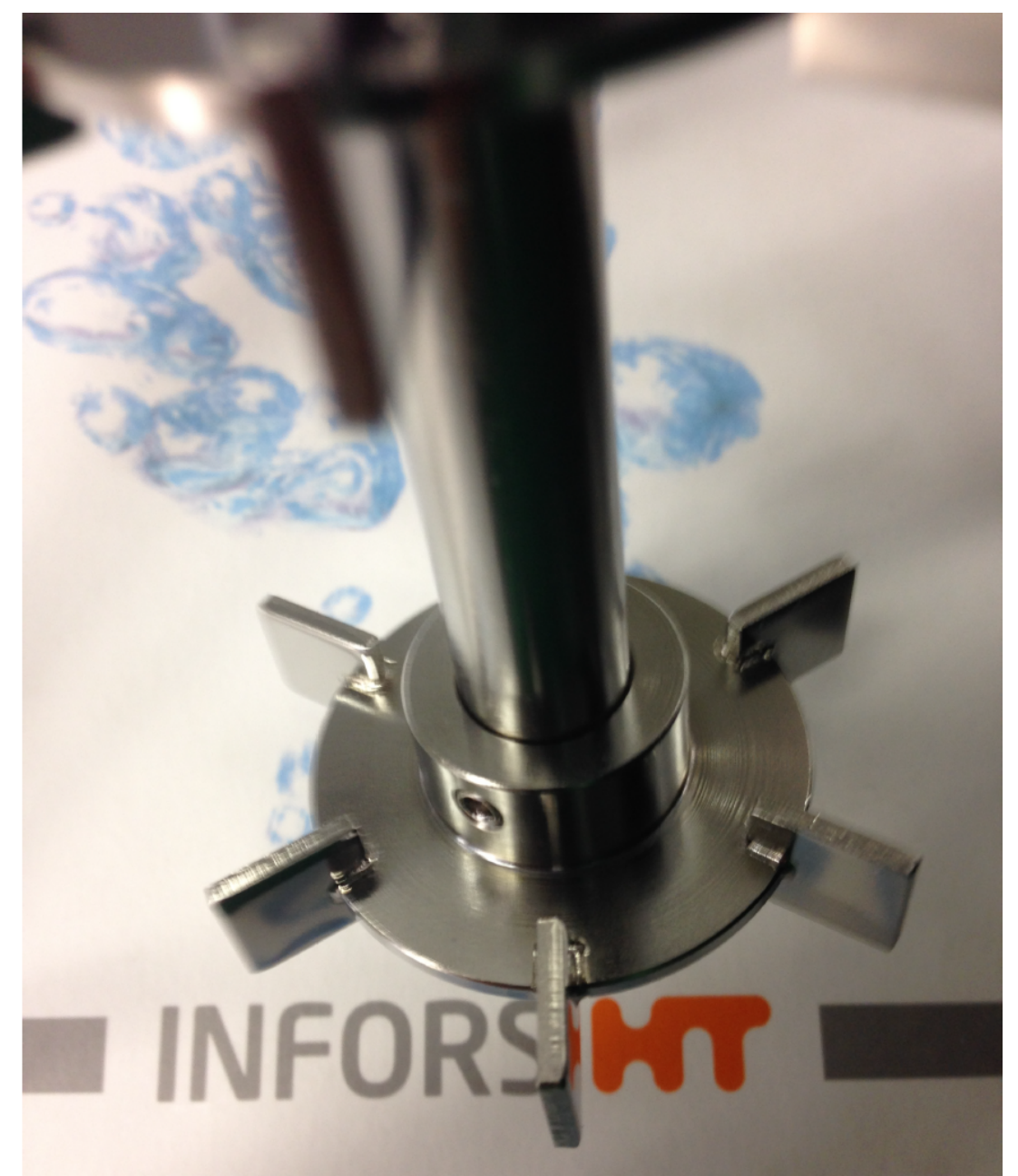

Figura A4 - Turbina do Modelo Rushton 


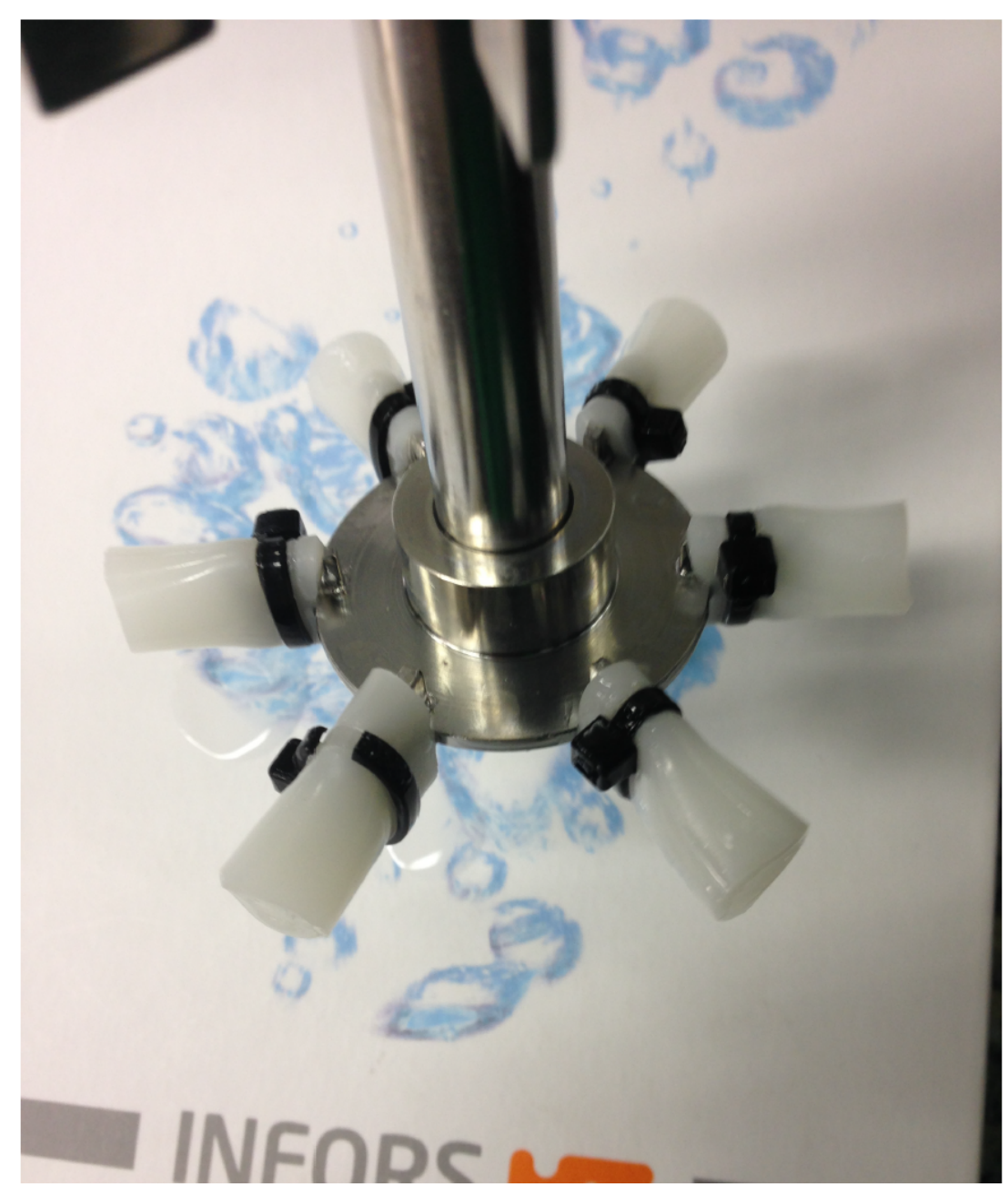

Figura A5 - Turbina do Modelo Rushton Modificada

Os valores de $\mathrm{k}_{\mathrm{L}} \mathrm{a}$ para $\mathrm{o}$ aspersor sinterizado com turbina de Rushton modificada (Tabela A4) foram superiores em relação às outras configurações disponíveis.

Tabela A4 - Valores de k $\mathrm{L}$ a para o Aspersor Sinterizado com a Turbina de Modelo Rushton Modificada

\begin{tabular}{cc}
\hline Agitação (RPM) & $\mathbf{k}_{\llcorner} \mathbf{a}\left(\mathbf{h}^{-1}\right)$ \\
\hline 250 & 68,23 \\
350 & 78,59 \\
450 & 99,05 \\
550 & 133,34 \\
600 & 149,08 \\
\hline
\end{tabular}


Com a configuração do aspersor sinterizado e a turbina de modelo Rushton modificada, foi possível obter valores de $\mathrm{k}_{\mathrm{L} a}$ que poderiam permitir uma nova tentativa da realização de cultivos de alta densidade celular. 